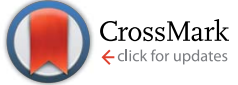

Cite this: RSC Adv., 2017, 7, 10158
Received 3rd January 2017

Accepted 30th January 2017

DOI: 10.1039/c7ra00073a

rsc.li/rsc-advances

\section{The reactions of $\alpha$-amino acids and $\alpha$-amino acid esters with high valent transition metal halides: synthesis of coordination complexes, activation processes and stabilization of $\alpha$-ammonium acylchloride cations $\uparrow$}

\author{
Lorenzo Biancalana, ${ }^{a}$ Marco Bortoluzzi, ${ }^{b}$ Eleonora Ferretti,,$^{a}$ Mohammad Hayatifar, ${ }^{a}$ \\ Fabio Marchetti, ${ }^{a}$ Guido Pampaloni ${ }^{* a}$ and Stefano Zacchini ${ }^{\mathrm{C}}$
}

\begin{abstract}
Titanium tetrachloride smoothly reacted with a selection of $\alpha$-amino acids (aaH) in $\mathrm{CH}_{2} \mathrm{Cl}_{2}$ affording yellow to orange solid coordination compounds, $1 a-d$, in $70-78 \%$ yields. The salts $\left[\mathrm{NHEt}_{3}\right]\left[\mathrm{TiCl}_{4}(\mathrm{aa})\right], 2 \mathrm{a}-\mathrm{b}$, were obtained from $\mathrm{TiCl}_{4} / \mathrm{aaH} / \mathrm{NEt}_{3}$ ( $\mathrm{aa}=\mathrm{L}$-phenylalanine, $\mathrm{N}, \mathrm{N}$-dimethylphenylalanine), in $60-65 \%$ yields. The complex $\mathrm{Nb}_{2} \mathrm{Cl}_{8}\left\{\mu-\kappa^{2} \mathrm{O}, \kappa^{2} \mathrm{~N}-\left[\overparen{\mathrm{CHCH}}_{2} \mathrm{CH}_{2} \mathrm{CH}(\mathrm{N}) \mathrm{CH}(\mathrm{O})\right]_{2}\right\}$, 3, was isolated from the reaction of L-proline with $\mathrm{NbCl}_{5} / \mathrm{NH}^{\prime} \mathrm{Pr}_{2}$, performed in $\mathrm{CH}_{2} \mathrm{Cl}_{2}$ at room temperature. The X-ray structure of 3 features a bridging (E)-1,2-bis(3,4-dihydro-2H-pyrrol-5-yl)ethene-1,2-diolate ligand, resulting from the unprecedented $\mathrm{C}-\mathrm{C}$ coupling between two proline units. Unusually stable $\alpha$-ammonium acyl chlorides were prepared by the reactions of $\mathrm{PCl}_{5} / \mathrm{MCl}_{n}\left(\mathrm{MCl}_{n}=\mathrm{NbCl}_{5}, \mathrm{WCl}_{6}\right)$ with L-proline, $\mathrm{N}, \mathrm{N}$-dimethylphenylalanine, sarcosine and Lmethionine. $\mathrm{MX}_{5}(\mathrm{M}=\mathrm{Nb}, \mathrm{Ta} ; \mathrm{X}=\mathrm{F}, \mathrm{Cl})$ reacted with L-leucine methylester and L-proline ethylester to give ionic coordination compounds, $\left[\mathrm{MX}_{4} \mathrm{~L}_{2}\right]\left[\mathrm{MX}_{6}\right]\left(\mathrm{M}=\mathrm{Nb}, \mathrm{L}=\mathrm{Me}_{2} \mathrm{CHCH}_{2} \mathrm{CH}\left(\mathrm{NH}_{2}\right) \mathrm{CO}_{2} \mathrm{Me}, \mathrm{X}=\mathrm{F}, 9 ; \mathrm{Cl}\right.$, 11a; $\mathrm{M}=\mathrm{Nb}, \quad \mathrm{X}=\mathrm{Cl}, \mathrm{L}=\mathrm{HNCH}_{2} \mathrm{CH}_{2} \mathrm{CH}_{2} \mathrm{CHCO}_{2} \mathrm{Et}, 11 \mathrm{c}$; Ta, 11d), in moderate to good yields. $\left[\mathrm{NbCl}_{5}\left(\mathrm{Me}_{2} \mathrm{CHCH}_{2} \mathrm{CHNH}_{3} \mathrm{CO}_{2} \mathrm{Me}\right)\right]\left[\mathrm{NbCl}_{6}\right], 12$, was isolated as a co-product of the reaction of $\mathrm{NbCl}_{5}$ with L-leucine isopropylester, and crystallographically characterized. The reaction of $\mathrm{NbCl}_{5}$ with L-serine isopropylester afforded $\mathrm{NbCl}_{3}\left(\mathrm{OCH}_{2} \mathrm{CHNHCO}_{2}{ }^{\mathrm{i}} \mathrm{Pr}\right), 13$, in $66 \%$ yield. The activation of the ester $\mathrm{O}-\mathrm{R}$ bond was observed in the reactions of L-leucine methyl ester with $\mathrm{NbF}_{5}$ and L-proline ethyl ester with $\mathrm{MBr}_{5}(\mathrm{M}=$ $\mathrm{Nb}, \mathrm{Ta}$ ), these reactions proceeding with the release of $\mathrm{EtF}$ and $\mathrm{EtBr}$, respectively. All the metal products were characterized by analytical and spectroscopic methods, while DFT calculations were carried out in order to provide insight into the structural and mechanistic aspects.
\end{abstract}

\section{Introduction}

$\alpha$-Amino acids constitute a class of organic compounds arousing great interest in synthetic chemistry, in view of their easy availability and low toxicity, ${ }^{1}$ the typical presence of

\footnotetext{
${ }^{a}$ University of Pisa, Dipartimento di Chimica e Chimica Industriale, Via G. Moruzzi 13, I-56124 Pisa, Italy.E-mail: guido.pampaloni@unipi.it; Web: http://www.dcci.unipi.it/ guido-pampaloni.html; Tel: +390502219221

${ }^{b} \mathrm{Ca}$ Foscari University of Venice, Dipartimento di Scienze Molecolari e Nanosistemi, Via Torino 155, I-30175 Mestre, Venezia, Italy

'University of Bologna, Dipartimento di Chimica Industriale "Toso Montanari", Viale Risorgimento 4, I-40136 Bologna, Italy

$\dagger$ Electronic supplementary information (ESI) available: Bond distances and angles and H-bond distances for compound $\mathbf{4}$ and for $[\mathbf{1 2}]^{-}$. The DFT-calculated structures discussed in this paper. CCDC 1041071, 1041072, 1518993 and 1518994 For ESI and crystallographic data in CIF or other electronic format see DOI: $10.1039 / \mathrm{c} 7 \mathrm{ra} 00073 \mathrm{a}$

\$ Present address: Institut für Anorganische Chemie, Georg-August-Universität Göttingen, Tammannstrasse 4, D-37077 Göttingen, Germany.
}

a stereogenic centre (making them suitable substrates for asymmetric catalysis) ${ }^{2}$ and the possibility of firmly coordinating metal ions. ${ }^{3}$

The esterification of the carboxylic acid moiety is one of the most viable modifications of the $\alpha$-amino acid skeleton, and indeed a good number of $\alpha$-amino acid esters have been synthesized and employed with reference to several application fields. ${ }^{4}$ Metal complexes containing $\alpha$-amino acid esters as ligands are especially relevant to bio-inorganic chemistry, being useful to the synthesis of peptides, ${ }^{5,6}$ as biological models, ${ }^{7}$ and as scaffolds for the development of new drugs. ${ }^{8}$ Furthermore, $\alpha$ amino acids and $\alpha$-amino acid ester metal complexes, being possible chiral sources, ${ }^{9}$ have found increasing attention as privileged, potential catalysts for environmentally friendly asymmetric syntheses. ${ }^{2 h, 10}$

It is noteworthy that the large majority of these studies refer to middle to late transition metals, whereas very little is known about the parallel chemistry with early transition metal compounds. In particular, the homoleptic halides of high valent 
elements (oxidation state $\geq 4$ ) belonging to groups 4, 5 and 6 , HVTMH, are strongly oxophilic species, usually very air sensitive and incompatible with water. This characteristic has probably discouraged the linking with an "opposite world", i.e. the exploration of the reactivity with $\alpha$-amino acids, which in turn exhibit high water affinity, and their simple derivatives such as $\alpha$-amino acid esters.

As a matter of fact, the coordination chemistry of HVTMH with $\alpha$-amino acid esters still remains an unexplored field of research, with the exception of a former synthetic study regarding $\mathrm{MoCl}_{5} \cdot{ }^{11}$ Similarly, the only information available up to 2014 on the interaction of HVTMH with $\alpha$-amino acids, in the absence of further reactants, is a note dealing with the reactivity of $\mathrm{TiCl}_{4}$ with glycine. ${ }^{12}$ In all of the cases, the structural characterization of the products relied on limited data.

Recently, in the framework of our interest in the chemistry of HVTMH with naturally occurring compounds, ${ }^{13}$ we have found that $\mathrm{MoCl}_{5}$ and $\mathrm{WCl}_{6}$ behave as chlorinating agents towards natural $\alpha$-amino acids, affording fairly stable $\alpha$-ammonium acylchloride salts. ${ }^{\mathbf{1 4}}$

On the other hand, the interaction of $\mathrm{MX}_{5}(\mathrm{M}=\mathrm{Nb}, \mathrm{Ta} ; \mathrm{X}=$ $\mathrm{Cl}, \mathrm{Br})$ with $\alpha$-amino acids leads to dinuclear complexes containing bridging $\alpha$-amino acidato ligands via $\mathrm{HX}$ release. ${ }^{15}$ Subsequent activation of the coordinated $\alpha$-amino acidato moiety has been observed in mild conditions in some specific cases, leading to iminium salts.

Herein, we will present an extension of our study on the reactivity between $\alpha$-amino acids and HVTMH, including the synthesis of $\mathrm{TiCl}_{4}$ derivatives, the unprecedented metal mediated $\mathrm{C}-\mathrm{C}$ dimerization of a $\alpha$-amino acid (L-proline) and the stabilization of otherwise reactive $\alpha$-ammonium acylchloride cations. We will also describe some reactivity of $\alpha$-amino acid ester with niobium and tantalum pentahalides. ${ }^{16,17}$ All the reactions were carried out in a weakly coordinating solvent $\left(\mathrm{CH}_{2} \mathrm{Cl}_{2}\right)$ by using enantiopure L-organic reactants in case. The metal products were characterized by elemental analysis, IR and NMR spectroscopy, while DFT calculations assisted the structural characterization. A DFT study was performed also in order to shed some light on the $\mathrm{NbCl}_{5}$-directed unusual L-proline pseudo dimerization.

\section{Results and discussion}

\section{Reactivity of $\mathrm{MCl}_{n}$ with $\alpha$-amino acids}

Titanium tetrachloride. Titanium tetrachloride smoothly reacted with a series of $\alpha$-amino acids in dichloromethane affording moisture sensitive, yellow to orange solid materials $\mathbf{1 a - d}$, in 70 to $78 \%$ yields (Scheme 1 ). Compounds 1 are coordination adducts: in this respect, the reactivity of $\mathrm{TiCl}_{4}$ with $\alpha$-amino acids differs from that of $\mathrm{MCl}_{5}(\mathrm{M}=\mathrm{Nb}$, Ta), featured by $\mathrm{HCl}$ release, ${ }^{15}$ and from those of $\mathrm{MoCl}_{5}$ and $\mathrm{WCl}_{6}$, leading to $\mathrm{Cl} / \mathrm{O}$ interchange products (see Introduction). ${ }^{\mathbf{1 4}}$

Compounds 1a-d were characterized by analytical and spectroscopic methods. The IR spectra (solid state) contain one medium and one strong intensity absorption in the range 1600$1400 \mathrm{~cm}^{-1}$. These two absorptions are due, respectively, to the asymmetric $\left(\nu_{\mathrm{a}}\right)$ and the symmetric $\left(\nu_{\mathrm{s}}\right)$ stretching vibrations of

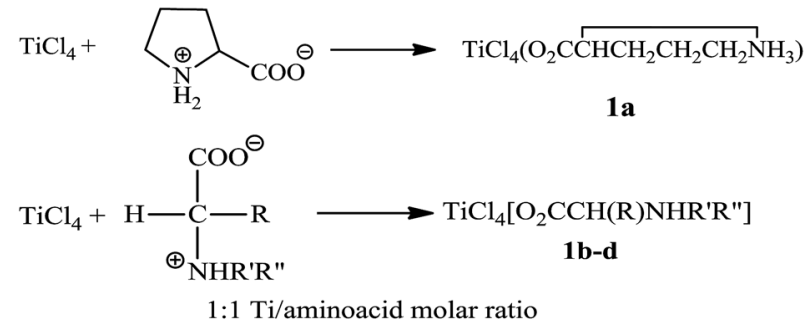

$\begin{array}{llll}\quad \mathrm{R} & \mathrm{R}^{\prime} & \mathrm{R} & \\ \mathrm{CH}_{2} \mathrm{Ph} & \mathrm{H} & \mathrm{H} & \mathbf{1 b} \\ \mathrm{H} & \mathrm{CH}_{3} & \mathrm{H} & \text { 1c } \\ \mathrm{H} & \mathrm{CH}_{3} & \mathrm{CH}_{3} & \text { 1d }\end{array}$

Scheme 1 Synthesis of titanium tetrachloride $\alpha$-amino acid complexes.

the carboxylato group. In general, the wavenumber difference $\left(\Delta \nu_{\mathrm{a}-\mathrm{s}}=\nu_{\mathrm{a}}-\nu_{\mathrm{s}}\right)$ is considered as a useful parameter to discriminate between monodentate, chelating, and bridging bidentate carboxylato ligands. $\Delta \nu_{\mathrm{a}-\mathrm{s}}$ values within the range 100 to $150 \mathrm{~cm}^{-1}$ are typical of either chelating or bridging bidentate carboxylates. ${ }^{18}$ In view of the IR data available for $1 \mathrm{a}-\mathbf{d}$, i.e. $\Delta \nu_{\mathrm{a}-\mathrm{s}}$ varies between 103 (1a) and 135 (1d) $\mathrm{cm}^{-1}$, and the DFT results (vide infra), we propose a bridging bidentate-coordination fashion. This implies that the amino acid ligand should be coordinated to titanium as a zwitterion. Accordingly, a broad IR absorption is observed at $3091 \mathrm{~cm}^{-1}$ in the IR spectrum of $\mathbf{1 d}$, assigned to ammonium $\mathrm{N}-\mathrm{H}$ stretching vibration.

The geometry proposed on the basis of spectroscopic data was supported by DFT calculations on the possible isomers of 1b. The dinuclear structure $\left[\mathrm{TiCl}_{4}\left(\mu-\kappa^{2} \mathrm{O}-\mathrm{O}_{2} \mathrm{CCH}\left(\mathrm{CH}_{2} \mathrm{Ph}\right) \mathrm{NH}_{3}\right)\right]_{2}$, depicted in Fig. 1, resulted meaningfully more stable than mononuclear structures (see Fig. S1 given as ESI†).

Compounds 1a-d display low solubility in common organic solvents. The NMR spectra were recorded in $\mathrm{CD}_{3} \mathrm{CN}$, displaying single sets of resonances. The ${ }^{1} \mathrm{H}$ NMR spectra exhibit broad

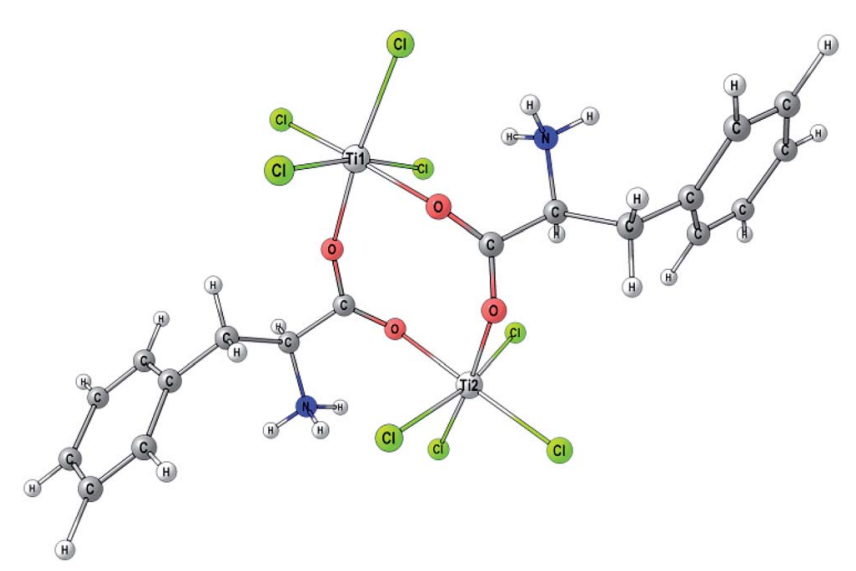

Fig. 1 DFT-optimized geometry of the most stable isomer of $1 \mathrm{~b}$ (C-PCM) M06 calculations). Selected computed bond lengths (Å): Ti1-O 2.020, 2.081; Ti2-O 1.990, 2.080; Ti1-Cl (trans O) 2.295, 2.232; Ti2-Cl (trans O) 2.232, 2.304; Ti1-Cl (cis O) 2.266, 2.392; Ti2-Cl (cis O) 2.291, 2.394; C-O $1.244,1.261,1.251,1.252 ; \mathrm{N}-\mathrm{H}$ 1.025, 1.028, 1.038, 1.027, 1.028, 1.037. Selected computed angles $\left({ }^{\circ}\right)$ : O-Ti1-O 86.1; O-Ti2-O 84.6; Ti1-O-C 149.8, 151.4; Ti2-O-C 139.2, 151.3; O-C-O 124.9, 126.4 


$$
\begin{aligned}
& \text { 1) } \stackrel{\ominus}{\mathrm{O}_{2} \mathrm{CCH}(\mathrm{R}) \stackrel{\oplus}{\mathrm{NHR}} \mathrm{R}^{\prime \prime}}
\end{aligned}
$$

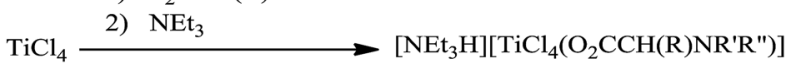

\begin{tabular}{clll} 
& $1: 1 \mathrm{Ti}^{2} \mathrm{NEt}_{3}$ molar ratio & \multicolumn{2}{c}{ 2a-b } \\
$\mathrm{R}$ & & & \\
$\mathrm{PhCH}_{2}$ & $\mathrm{R}$ & $\mathrm{R}$ & \\
$\mathrm{PhCH}_{2}$ & $\mathrm{H}$ & $\mathrm{H}$ & $\mathbf{2 a}$ \\
& $\mathrm{Me}$ & $\mathrm{Me}$ & $\mathbf{2 b}$
\end{tabular}

Scheme 2 Synthesis of anionic $\alpha$-aminoacidate titanium compounds.

resonances in the 7.7-7.0 ppm range, related to the uncoordinated ammonium group. The ${ }^{13} \mathrm{C}-\mathrm{NMR}$ spectra of the more soluble 1a-b show the resonance of the carboxylate carbon at 176.1 and $170.0 \mathrm{ppm}$, respectively. These values are similar to those reported for $O, O$-coordinated $\alpha$-amino acids in $\mathrm{NbCl}_{5}$ derivatives. ${ }^{15}$

The coordination of organic species to high valent transition metal chlorides represents, in a number of cases, the preliminary step of some activation process. ${ }^{13 c, 19}$ The activation is favoured by the strong Lewis acidity of the metal centre, and may be triggered by the addition of a Brönsted base. For instance, Peryshkov and coworkers recently described a C-H bond activation reaction of nitriles by means of $\mathrm{NEt}_{3}$ upon coordination to $\mathrm{TaCl}_{5} \cdot{ }^{20}$

Thus, the reaction of $\mathbf{1 b}$ with $\mathrm{NEt}_{3}$ proceeded with selective deprotonation of the ammonium group; analogous result was achieved by treatment of a $\mathrm{TiCl}_{4} / \mathrm{L}-\mathrm{L}, N$-dimethylphenylalanine mixture with $\mathrm{NEt}_{3}$ (Scheme 2). ${ }^{21}$ The reactions of $\mathbf{1 a}, \mathbf{c}, \mathbf{d}$ with $\mathrm{NEt}_{3}$ were not straightforward, leading to non identified compounds; the solid isolated from $\mathbf{1 a} / \mathrm{NEt}_{3}$ revealed to be paramagnetic.

The $\mathrm{CH}_{2} \mathrm{Cl}_{2}$ soluble compounds $\mathbf{2 a - b}$ (Scheme 2) were isolated by addition of hexane to the respective reaction mixtures. ${ }^{22}$

The ${ }^{1} \mathrm{H}$ NMR spectra of $\mathbf{2 a - b}$ display a low field resonance accounting for the triethylammonium proton (e.g. at $9.09 \mathrm{ppm}$ in the case of 2a); the resonances of the N-bound protons within the anion undergo significant upfield shift on going from the amino acid unit in $\mathbf{1 b}$ to the amino acidate one in $\mathbf{2 b}(\Delta \delta>3$ $\mathrm{ppm})$. The IR spectra of $\mathbf{2 a - b}$ exhibit a strong absorption around $1700 \mathrm{~cm}^{-1}$ : this evidence suggests $\mathrm{O}, \mathrm{N}$-coordination of the aminoacidate moiety, leaving a uncoordinated $\mathrm{C}=\mathrm{O}$ bond. The geometries of the $\mathbf{2 a , b}$ anions were DFT optimized, on considering either mononuclear and dinuclear structures as starting points (Fig. S2 $†$ ). Thus, mononuclear compounds bearing N,Ochelating $\alpha$-aminoacidates (Fig. 2) resulted much more stable than dinuclear homologues (see ESI $\dagger$ for more details).

Niobium pentachloride. We reported that the $2: 1$ reactions of $\mathrm{NbX}_{5}(\mathrm{X}=\mathrm{Cl}, \mathrm{Br})$ with a variety of $\alpha$-amino acids afforded dinuclear $\alpha$-aminoacidate complexes via $\mathrm{HCl}$ release. The addition of a further equivalent of organic reactant resulted in the decarboxylation of one amino acidate moiety, with consequent formation of iminium salts and Nb-formate species (see Scheme 3 , showing the specific case of $N, N$-dimethylphenylalanine). ${ }^{15}$

With the aim of exploring the possibility of further activation pathways, we investigated the reactions of $\mathrm{Nb}_{2} \mathrm{Cl}_{9}(\alpha$-amino
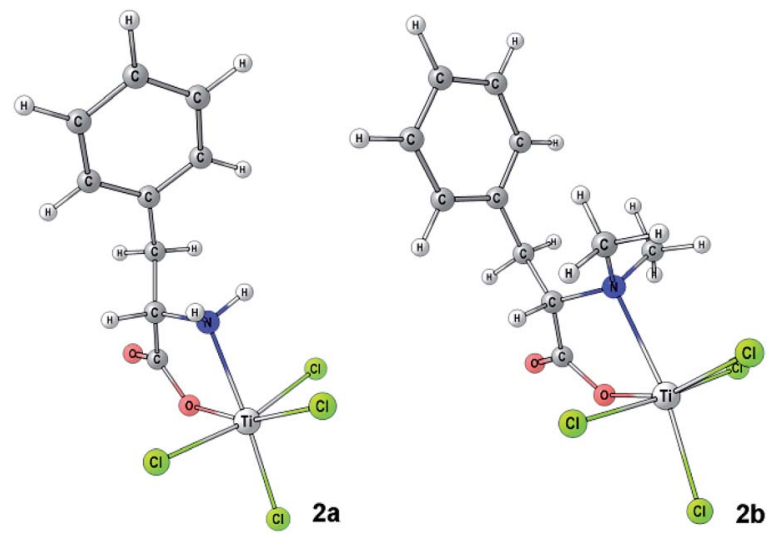

Fig. 2 DFT-optimized geometries of the most stable anions of $2 a$ and $2 \mathrm{~b}$ (C-PCM/M06 calculations). Selected computed bond lengths for $2 \mathrm{a}$ (Å): Ti-O 1.909; Ti-N 2.240; Ti-Cl (trans O) 2.321; Ti-Cl (trans N) 2.263; $\mathrm{Ti}-\mathrm{Cl}$ (trans $\mathrm{Cl}$ ) 2.340, 2.353; $\mathrm{C}-\mathrm{O} 1.316 ; \mathrm{C}=\mathrm{O} 1.212 ; \mathrm{N}-\mathrm{H}$ $1.018,1.021$. Selected computed angles for $2 \mathrm{a}\left({ }^{\circ}\right)$ : O-Ti-N 76.0; O-Ti$\mathrm{Cl}$ 87.8, 88.8, 97.6, 160.9; C-O-Ti 127.5. Selected computed bond lengths for $2 \mathrm{~b}(\AA \AA)$ : $\mathrm{Ti}-\mathrm{O} 1.893 ; \mathrm{Ti}-\mathrm{N} \mathrm{2.434;} \mathrm{Ti}-\mathrm{Cl}$ (trans O) $2.309 ; \mathrm{Ti}-\mathrm{Cl}$ (trans N) 2.271; $\mathrm{Ti}-\mathrm{Cl}$ (trans $\mathrm{Cl}$ ) 2.333, 2.354; $\mathrm{C}-\mathrm{O} 1.316 ; \mathrm{C}=\mathrm{O} 1.212$. Selected computed angles for $2 \mathrm{~b}\left(^{\circ}\right)$ : O-Ti-N 73.2; O-Ti-Cl 88.6, 89.7, 98.5, 160.3; C-O-Ti 130.2.<smiles></smiles><smiles>CC(CCCCC=O)C(=O)O</smiles>

$\left[\left(\mathrm{PhCH}_{2}\right) \mathrm{CH}=\mathrm{NMe}_{2}\right]\left[\mathrm{NbCl}_{6}\right]$ $\mathrm{NbCl}_{3}\left(\mathrm{O}_{2} \mathrm{CH}\right)\left[\mathrm{O}_{2} \mathrm{CCH}\left(\mathrm{CH}_{2} \mathrm{Ph}\right) \mathrm{NMe}_{2}\right]$

Scheme 3 Reaction of $\mathrm{NbCl}_{5}$ with $\mathrm{N}, \mathrm{N}$-dimethylphenylalanine.

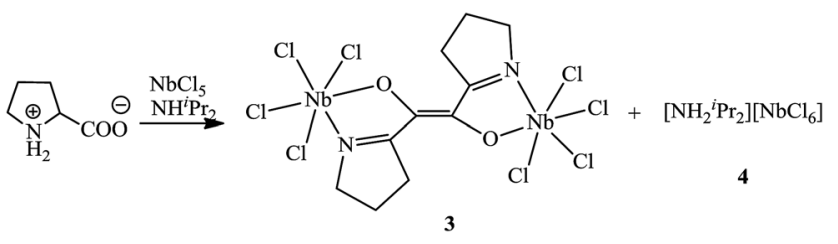

Scheme 4 Unusual activation of $\mathrm{L}$-proline by $\mathrm{NbCl}_{5} / \mathrm{amine}$.

acidate) complexes with $\mathrm{NEt}_{3}$. In general, the amino acidate moiety did not undergo activation under these conditions, with an exception provided by the $\mathrm{Nb}_{2} \mathrm{Cl}_{9}$ (L-prolinate)/ $\mathrm{NEt}_{3}$ system. This latter evolved into a complicated mixture of products, including minor amounts of $\mathrm{Nb}_{2} \mathrm{Cl}_{8}\left\{\mu-\kappa^{2} \mathrm{O}, \kappa^{2} \mathrm{~N}-\left[\widetilde{\mathrm{CH}}_{2} \mathrm{CH}_{2} \mathrm{CH}_{2} \mathrm{C}(\mathrm{N}) \mathrm{C}(\mathrm{O})\right]_{2}\right.$, 3. The use of $\mathrm{NH}^{\mathrm{i}} \mathrm{Pr}_{2}$ in the place of $\mathrm{NEt}_{3}$ allowed to isolate red crystals of $3\left(12 \%\right.$ yield), and also yellow crystals of $\left[\mathrm{NH}_{2}{ }^{\mathrm{i}} \mathrm{Pr}_{2}\right]$ [ $\left.\mathrm{NbCl}_{6}\right], 4$ (40\% yield), Scheme 4. 


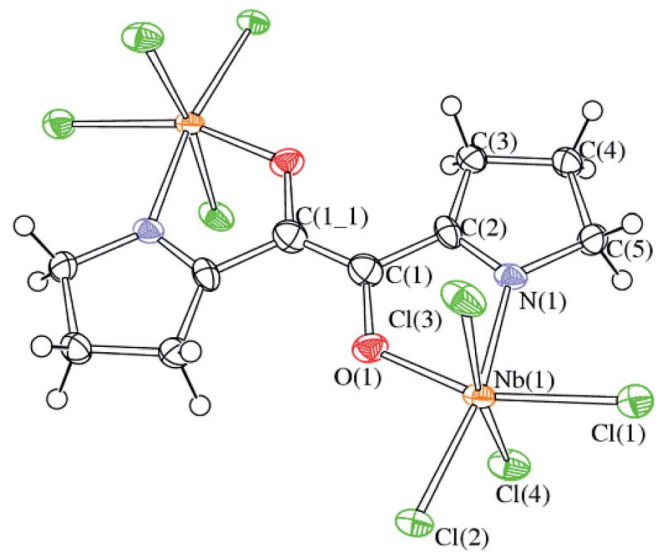

Fig. 3 ORTEP drawing of 3. Displacement ellipsoids are at the 50\% probability level.

Table 1 Selected bond lengths $(\AA)$ and angles $\left(^{\circ}\right)$ for $3^{a}$

\begin{tabular}{llll}
\hline $\mathrm{Nb}(1)-\mathrm{Cl}(1)$ & $2.3319(13)$ & $\mathrm{Nb}(1)-\mathrm{Cl}(2)$ & $2.2833(11)$ \\
$\mathrm{Nb}(1)-\mathrm{Cl}(3)$ & $2.3454(12)$ & $\mathrm{Nb}(1)-\mathrm{Cl}(4)$ & $2.3453(12)$ \\
$\mathrm{Nb}(1)-\mathrm{O}(1)$ & $1.927(3)$ & $\mathrm{Nb}(1)-\mathrm{N}(1)$ & $2.235(4)$ \\
$\mathrm{C}(1)-\mathrm{O}(1)$ & $1.357(6)$ & $\mathrm{C}(1)-\mathrm{C}\left(1 \_1\right)$ & $1.337(10)$ \\
$\mathrm{C}(1)-\mathrm{C}(2)$ & $1.471(7)$ & $\mathrm{C}(2)-\mathrm{C}(3)$ & $1.488(7)$ \\
$\mathrm{C}(3)-\mathrm{C}(4)$ & $1.530(6)$ & $\mathrm{C}(4)-\mathrm{C}(5)$ & $1.528(6)$ \\
$\mathrm{N}(1)-\mathrm{C}(2)$ & $1.276(6)$ & $\mathrm{N}(1)-\mathrm{C}(5)$ & $1.477(6)$ \\
$\mathrm{Cl}(1)-\mathrm{Nb}(1)-\mathrm{O}(1)$ & $158.18(10)$ & $\mathrm{Cl}(2)-\mathrm{Nb}(1)-\mathrm{N}(1)$ & $167.62(11)$ \\
$\mathrm{Cl}(3)-\mathrm{Nb}(1)-\mathrm{Cl}(4)$ & $170.32(5)$ & $\mathrm{O}(1)-\mathrm{Nb}(1)-\mathrm{N}(1)$ & $73.03(14)$ \\
$\mathrm{Nb}(1)-\mathrm{O}(1)-\mathrm{C}(1)$ & $122.9(3)$ & $\mathrm{Nb}(1)-\mathrm{N}(1)-\mathrm{C}(2)$ & $117.6(3)$ \\
$\mathrm{Nb}(1)-\mathrm{N}(1)-\mathrm{C}(5)$ & $132.0(3)$ & $\mathrm{C}(2)-\mathrm{N}(1)-\mathrm{C}(5)$ & $110.4(4)$ \\
$\mathrm{N}(1)-\mathrm{C}(2)-\mathrm{C}(3)$ & $115.8(4)$ & $\mathrm{N}(1)-\mathrm{C}(2)-\mathrm{C}(1)$ & $110.7(4)$ \\
$\mathrm{C}(1)-\mathrm{C}(2)-\mathrm{C}(3)$ & $133.5(4)$ & $\mathrm{C}(2)-\mathrm{C}(3)-\mathrm{C}(4)$ & $102.3(4)$ \\
$\mathrm{C}(3)-\mathrm{C}(4)-\mathrm{C}(5)$ & $105.8(4)$ & $\mathrm{C}(4)-\mathrm{C}(5)-\mathrm{N}(1)$ & $105.7(4)$ \\
$\mathrm{O}(1)-\mathrm{C}(1)-\mathrm{C}(2)$ & $114.6(4)$ & $\mathrm{O}(1)-\mathrm{C}(1)-\mathrm{C}(1-1)$ & $120.2(6)$ \\
$\mathrm{C}(2)-\mathrm{C}(1)-\mathrm{C}(1-1)$ & $125.2(6)$ & &
\end{tabular}

$\mathrm{C}(2)-\mathrm{C}(1)-\mathrm{C}\left(1 \_1\right) \quad 125.2(6)$

${ }^{a}$ Symmetry transformation used to generate $\mathrm{C}\left(1 \_1\right):-x+1,-y,-z+1$.

The X-ray structure of 3 is shown in Fig. 3, with relevant bonding parameters listed in Table 1; the X-ray structure of 4 is given as ESI (Fig. S3; Tables S1A and S1B $\dagger$ ).

Complex 3 displays crystallographic $\overline{1}\left(C_{i}\right)$ symmetry with the inversion centre located on the middle of the $\mathrm{C}(1)-\mathrm{C}\left(1 \_1\right)$ bond. The complex is composed of an unprecedented anionic $\left[\mathrm{CH}_{2} \mathrm{CH}_{2} \mathrm{CH}_{2} \mathrm{CH}(\mathrm{N}) \mathrm{CH}(\mathrm{O})\right]_{2}{ }_{2}^{2-}$ ligand (E-1,2-bis(3,4-dihydro-2H-pyrrol-5yl)ethene-1,2-diolate) that is $\mu-\kappa^{2} \mathrm{O}, \kappa{ }^{2} \mathrm{~N}$-coordinated over two $\left[\mathrm{NbCl}_{4}\right]^{+}$cationic fragments. Such anionic ligand is almost perfectly planar (mean deviation from the least squares plane $0.0387 \AA$ ), being the two $\mathrm{Nb}$ atoms respectively $0.1879 \AA$ above and below this plane. $\mathrm{C}(1), \mathrm{C}(2)$ and $\mathrm{N}(1)$ [sum angles 360.0(9), $360.0(7)$ and $360.0(6)^{\circ}$, respectively] show a perfect $\mathrm{sp}^{2}$ hybridization, and the $\mathrm{C}(1)-\mathrm{C}\left(1 \_1\right)[1.357(6) \AA]$ and $\mathrm{C}(2)-\mathrm{N}(1)[1.276(6)$ $\AA$ ] distances are typical for double bonds. ${ }^{23}$

The $\left\{\mathrm{C}_{2} \mathrm{O}_{2}\right\}$ core of the (E)-1,2-bis(3,4-dihydro-2H-pyrrol-5-yl) ethene-1,2-diolate ligand in 3 is a fully deprotonated 1,2-enediol. In general, 1,2-enediols are quite unstable species, ${ }^{24}$ whose stabilization may be supplied by hydrogen-bonded protons, ${ }^{25}$ or by chelating $(\mathrm{N}, \mathrm{O})$ coordination to transition metals. ${ }^{26}$

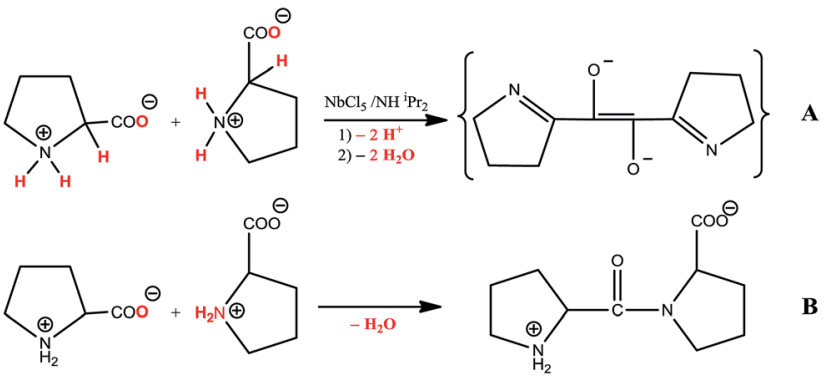

Scheme $5 \mathrm{NbCl}_{5}$-promoted $\mathrm{C}-\mathrm{C}$ pseudo-dimerization of L-proline (A); peptide bond formation from two L-proline units (B).

Basically, the process leading to 3 is a $\mathrm{C}-\mathrm{C}$ bond forming condensation of two proline units (Scheme 5A). Differently, typical $\alpha$-amino acid condensation generates a peptide bond (Scheme 5B). ${ }^{27}$

In order to gain some insight into the mechanism of the low yield formation of 3, a DFT study was undertaken (see Scheme S1 in the $\mathrm{ESI} \dagger$ ). It seems plausible that the $\mathrm{C}-\mathrm{C}$ bond forming step consists in the coupling of two acylchloride units, accompanied by the release of $\mathrm{HCl}$ and assisted by the amine (see Scheme $\mathrm{S} 1, \dagger$ $\mathrm{E} \rightarrow \mathrm{F} \rightarrow \mathrm{G})$. Indeed the side reactions $\mathrm{NH}^{\mathrm{i}} \mathrm{Pr}_{2}+\mathrm{HCl} \rightarrow$ $\left[\mathrm{NH}_{2}{ }^{\mathrm{i}} \mathrm{Pr}_{2}\right] \mathrm{Cl}$ and $\left[\mathrm{NH}_{2}{ }^{\mathrm{i}} \mathrm{Pr}_{2}\right] \mathrm{Cl}+\mathrm{NbCl}_{5} \rightarrow \mathbf{4}$ should contribute to decrease the $\Delta G$ variation of the process leading to 3 .

The crystals of 3 exhibited insufficient solubility in suitable deuterated solvents, thus preventing the NMR characterization.

$\mathbf{M C l}_{n} /$ phosphorous pentachloride $\left(\mathbf{M C l}_{n}=\mathbf{N b C l}_{5}, \mathbf{W C l}_{6}\right)$. The carboxylic acid to acyl chloride conversion is an important preliminary step for the subsequent functionalization of $\alpha$ amino acids. ${ }^{28} \mathrm{PCl}_{5}$ has been traditionally employed as $\mathrm{Cl}$ source in order to obtain the relevant $\alpha$-ammonium acylchloride salts (Fischer procedure); the counterion is $\mathrm{Cl}^{-}$or $\left[\mathrm{PCl}_{6}\right]^{-}$depending on the employed $\mathrm{PCl}_{5} / \alpha$-aminoacid molar ratio. $^{29} \alpha$-Ammonium acylchloride species stable at room temperature have been obtained only with primary ammonium groups and in the absence of donor atoms within the side chain. On the other hand, in the case of the L-proline derivative (secondary $\mathrm{N}$ ), both $\mathrm{Cl}^{-}$and $\left[\mathrm{PCl}_{6}\right]^{-}$salts undergo quick degradation at room temperature, due to $\mathrm{HCl}$ release and subsequent condensation reactions. ${ }^{29}$ Furthermore, the reactions of $\mathrm{PCl}_{5}$ with $\mathrm{L}-\mathrm{N}, \mathrm{N}$-dimethylphenylalanine (tertiary $\mathrm{N}$ ), sarcosine (secondary $\mathrm{N}$ ) and L-methionine (thioether group), in $\mathrm{CH}_{2} \mathrm{Cl}_{2}$, proceed with the formation of complicated mixtures of products $\left({ }^{1} \mathrm{H}\right.$ and ${ }^{31} \mathrm{P}$ NMR spectroscopy). Thus, the $\mathrm{L}-\mathrm{N}, \mathrm{N}$ dimethylphenylalanine and L-methionine acylchloride derivatives have not been known heretofore, while the highly moisture sensitive $\left[\mathrm{NH}(\mathrm{Me}) \mathrm{CH}_{2} \mathrm{COCl}\right]\left[\mathrm{WOCl}_{5}\right]$ has been recently obtained by ourselves from sarcosine/ $\mathrm{WCl}_{6}{ }^{14 a}$

Some of us recently reported ${ }^{\mathbf{1 3 b , 2 9}}$ a straightforward and clean route to unusually stable salts of the acylchloride derivative of $\mathrm{L}^{-}$ proline, by combination of the traditional $\mathrm{PCl}_{5}$-chlorinating reaction with the considerable stability imparted by the $\left[\mathrm{MCl}_{6}\right]^{-}$ $(\mathrm{M}=\mathrm{Nb}, \mathrm{Ta})$ anions, Scheme $6 .^{\mathbf{1 3 b - c , 3 0}}$

We reckoned that the easily available $\left[\mathrm{NbCl}_{6}\right]^{-}$anion could provide stability also to other unstable/unknown $\alpha$-ammonium acylchloride cations (see above). Therefore, we tried to optimize 
and generalize the synthetic procedure shown in Scheme 6 . When a dichloromethane 1 : 1 molar mixture of $\mathrm{PCl}_{5}$ and $\mathrm{NbCl}_{5}$ was treated with $\mathrm{L}-N, N$-dimethylphenylalanine or sarcosine, ${ }^{31}$ the subsequent ${ }^{31} \mathrm{P}$ NMR analysis on the reaction solution evidenced the presence of $\mathrm{POCl}_{3}$ as prevalent phosphorous species [singlet at $6.2 \mathrm{ppm}$ (from $\mathrm{PCl}_{5} / \mathrm{NbCl}_{5} / \mathrm{L}-\mathrm{N}, \mathrm{N}$-dimethylphenylalanine) and $5.6 \mathrm{ppm}$ (from $\mathrm{PCl}_{5} / \mathrm{NbCl}_{5} /$ sarcosine), respectively]. ${ }^{13 b, 29,32}$ The corresponding $\left[\mathrm{NbCl}_{6}\right]^{-} \alpha$-ammonium acylchloride salts, $\mathbf{5 a}-\mathbf{b}$, were isolated at room temperature in 40-50\% yields (Scheme 7 ). The presence of $\left[\mathrm{NbCl}_{6}\right]^{-}$in $\mathbf{5 a - b}$ was unambiguously detected by a typical ${ }^{93} \mathrm{Nb}$ NMR resonance around 0 ppm. ${ }^{13 c, 33}$ The structure of $5 \mathbf{a}$ was determined by X-ray diffraction (Fig. 4, Table 2). It contains the $\left[\mathrm{PhCH}_{2} \mathrm{CH}\left(\mathrm{NHMe}_{2}\right)\right.$ $\mathrm{COCl}]^{+}$cation, which has never been reported heretofore. Within crystals of 5a, some intermolecular $\mathrm{N}-\mathrm{H} \cdots \mathrm{Cl}$ hydrogen bonds are present involving the ammonium group of the cation as donor and the chloride ligands of the anion as an acceptor. The bonding parameters of the cation are comparable to those previously reported for other $\alpha$-ammonium acylchloride salts. ${ }^{13 b, 14,29}$ Thus, the $\mathrm{C}(1)-\mathrm{O}(1)$ distance $[1.178(5) \AA]$ corresponds to an almost pure double bond, whereas all the other contacts are typical for single bonds. ${ }^{34}$ The $\mathrm{C}(2)$ atoms displays an absolute $S$ configuration with refined Flack parameter $0.03(2) .^{35}$

The iminium salt $\left[\mathrm{PhCH}_{2}=\mathrm{NMe}_{2}\right]\left[\mathrm{NbCl}_{6}\right]$ (see Scheme 3) and the adduct $\mathrm{NbCl}_{5}\left(\mathrm{O}=\mathrm{PCl}_{3}\right), \mathbf{6}$, identified by comparison of the

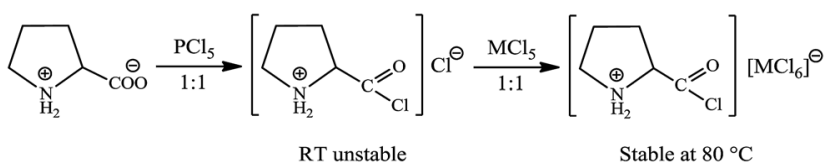

Scheme 6 Stable pyrrolidinium-2-carbonylchloride salts from Lproline and $\mathrm{MCl}_{5}(\mathrm{M}=\mathrm{Nb}, \mathrm{Ta})$.

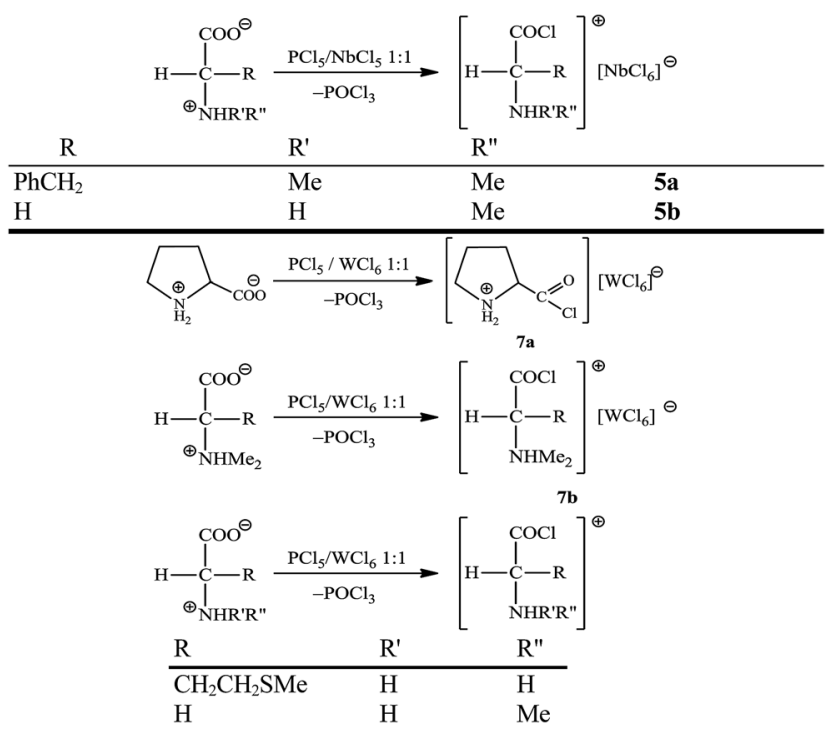

Scheme 7 Formation of otherwise unstable $\alpha$-ammonium acylchloride cations from $\alpha$-amino acids and niobium and tungsten chlorides. crystal cell data with those reported in the literature, ${ }^{36}$ were obtained as minor products from $\mathrm{NbCl}_{5} / \mathrm{L}-\mathrm{N}, \mathrm{N}$-dimethylphenylalanine and $\mathrm{NbCl}_{5} /$ sarcosine, respectively.

The synthetic approach leading to $\mathbf{5 a - b}$ exploits the $\mathrm{M}-\mathrm{Cl}$ $(\mathrm{M}=\mathrm{P}, \mathrm{Nb})$ bond energy scale,${ }^{13 b, 37}$ making $\mathrm{PCl}_{5}$ a preferential chlorinating agent respect to $\mathrm{NbCl}_{5}$, and the stability of the $\left[\mathrm{NbCl}_{6}\right]^{-}$anion. Similar considerations led us to test the $\mathrm{PCl}_{5} / \mathrm{WCl}_{6}$ mixture; it should be noted that anionic simple derivatives of $\mathrm{WCl}_{6}$ (i.e., $\mathrm{WCl}_{6}, \mathrm{WOCl}_{5}{ }^{-}$) have recently proposed as effective partners for the stabilization of otherwise reactive cations. ${ }^{14 a, 38}$

Hence, the reactions of $\mathrm{PCl}_{5} / \mathrm{WCl}_{6}$ (1:1 mixture) with L-proline, L- $N, N$-dimethylphenylalanine, sarcosine and L-methionine proceeded with $\mathrm{PCl}_{5}$ to $\mathrm{POCl}_{3}$ conversion $\left({ }^{31} \mathrm{P} \mathrm{NMR}\right)$, and straightforwardly afforded the respective $\alpha$-ammonium acylchloride cations (Scheme 7). According to elemental analyses and magnetic measurements, ${ }^{38}$ the cations were isolated in good yields as $\left[\mathrm{WCl}_{6}\right]^{-}$salts, $7 \mathbf{a}-\mathbf{b}$, respectively from $\mathrm{PCl}_{5} / \mathrm{WCl}_{6} /$ L-proline and $\mathrm{PCl}_{5} / \mathrm{WCl}_{6} / \mathrm{L}-\mathrm{N}, \mathrm{N}$-dimethylphenylalanine. Otherwise, different anions were presumably associated with sarcosine and methionine derivatives, including $\left[\mathrm{WOCl}_{5}\right]^{-}$(few crystals of $\left[\mathrm{MeNH}_{2} \mathrm{CH}_{2} \mathrm{C}(=\mathrm{O}) \mathrm{Cl}\right]\left[\mathrm{WOCl}_{5}\right]$ were isolated and $\mathrm{X}$ ray characterized) and $\mathrm{W}(\mathrm{Iv})$ species.

The characterization of the $1: 1$ mixture $\mathrm{WCl}_{6} / \mathrm{PCl}_{5}$ suggested that both chlorides remained intact when mixed together (see Experimental for details). This implies that the $\mathrm{WCl}_{6}$ to $\mathrm{WCl}_{6}{ }^{-}$reduction, as clearly observed in $7 \mathbf{a}-\mathbf{b}$, is promoted by the $\alpha$-amino acid. Analogous $\mathrm{WCl}_{6}$ reduction has
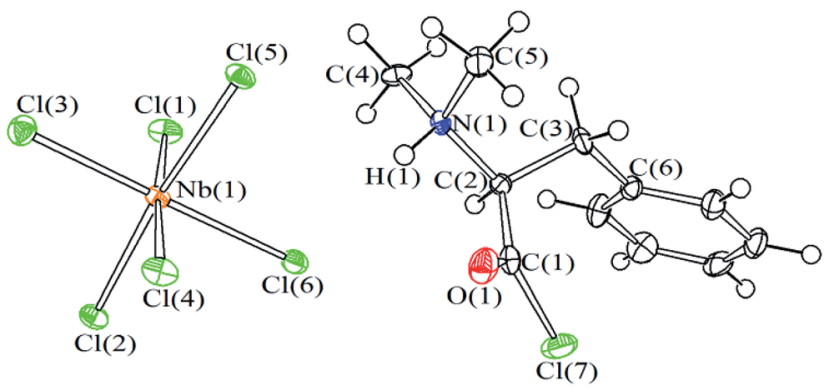

Fig. 4 ORTEP drawing of 5a. Displacement ellipsoids are at the 50\% probability level.

Table 2 Selected bond lengths $(\AA)$ and angles $\left(^{\circ}\right)$ for $5 a$

\begin{tabular}{llll}
\hline $\mathrm{Nb}(1)-\mathrm{Cl}(1)$ & $2.3305(11)$ & $\mathrm{Nb}(1)-\mathrm{Cl}(2)$ & $2.3344(11)$ \\
$\mathrm{Nb}(1)-\mathrm{Cl}(3)$ & $2.2921(11)$ & $\mathrm{Nb}(1)-\mathrm{Cl}(4)$ & $2.3475(11)$ \\
$\mathrm{Nb}(1)-\mathrm{Cl}(5)$ & $2.3844(11)$ & $\mathrm{Nb}(1)-\mathrm{Cl}(6)$ & $2.4206(11)$ \\
$\mathrm{C}(1)-\mathrm{Cl}(7)$ & $1.758(5)$ & $\mathrm{C}(1)-\mathrm{O}(1)$ & $1.178(5)$ \\
$\mathrm{C}(1)-\mathrm{C}(2)$ & $1.516(7)$ & $\mathrm{C}(2)-\mathrm{C}(3)$ & $1.553(6)$ \\
$\mathrm{C}(2)-\mathrm{N}(1)$ & $1.500(6)$ & $\mathrm{N}(1)-\mathrm{C}(4)$ & $1.499(5)$ \\
$\mathrm{N}(1)-\mathrm{C}(5)$ & $1.501(6)$ & $\mathrm{C}(3)-\mathrm{C}(6)$ & $1.516(6)$ \\
$\mathrm{Cl}(1)-\mathrm{Nb}(1)-\mathrm{Cl}(4)$ & $176.12(5)$ & $\mathrm{Cl}(2)-\mathrm{Nb}(1)-\mathrm{Cl}(5)$ & $174.25(5)$ \\
$\mathrm{Cl}(3)-\mathrm{Nb}(1)-\mathrm{Cl}(6)$ & $179.14(4)$ & $\mathrm{O}(1)-\mathrm{C}(1)-\mathrm{Cl}(7)$ & $120.6(4)$ \\
$\mathrm{O}(1)-\mathrm{C}(1)-\mathrm{C}(2)$ & $125.4(4)$ & $\mathrm{Cl}(7)-\mathrm{C}(1)-\mathrm{C}(2)$ & $113.9(3)$ \\
$\mathrm{C}(1)-\mathrm{C}(2)-\mathrm{C}(3)$ & $115.1(4)$ & $\mathrm{C}(1)-\mathrm{C}(2)-\mathrm{N}(1)$ & $107.3(4)$ \\
$\mathrm{C}(2)-\mathrm{C}(3)-\mathrm{C}(6)$ & $115.1(4)$ & $\mathrm{C}(2)-\mathrm{N}(1)-\mathrm{C}(4)$ & $111.4(3)$ \\
$\mathrm{C}(2)-\mathrm{N}(1)-\mathrm{C}(5)$ & $114.9(3)$ & $\mathrm{C}(4)-\mathrm{N}(1)-\mathrm{C}(5)$ & $111.4(4)$
\end{tabular}


been previously observed in a number of cases by interaction with organic compounds. ${ }^{38,39}$

All the $\alpha$-ammonium acylchloride cations produced from $\mathrm{PCl}_{5} / \mathrm{NbCl}_{5}$ and $\mathrm{PCl}_{5} / \mathrm{WCl}_{6}$ were fully characterized by IR and NMR spectroscopy, and those cations derived from $\mathrm{L}-\mathrm{N}, \mathrm{N}$ dimethylphenylalanine and L-methionine are reported here for the first time. The chloro-acyl moiety manifests itself by a strong IR absorption in the region $1765-1783 \mathrm{~cm}^{-1}$, other than the ${ }^{13} \mathrm{C}$ NMR resonance in the range 169.0-171.7 ppm.

\section{Reactivity of $\mathrm{MCl}_{n}$ with $\alpha$-amino acid esters}

Preparation of $\alpha$-amino acid ester hydrochlorides and $\boldsymbol{\alpha}$-amino acid esters. The $\boldsymbol{\alpha}$-amino acid ester derivatives, $\mathbf{8}$, were prepared from the corresponding hydrochlorides, $\mathbf{8} \cdot \mathbf{H C l}$, which were in general isolated (Scheme 8). Although most of the compounds $\mathbf{8}$ and $\mathbf{8} \cdot \mathbf{H C l}$ have been already appeared in the literature, ${ }^{\mathbf{4 0}}$ we decided to collect their preparations and IR and NMR data in this paper, in view of possible modifications to the reported procedures or additional spectroscopic data.

Reactions with niobium and tantalum pentahalides. The reactions of $\alpha$-amino acid esters with $\mathrm{NbF}_{5}$ are often non selective, affording in most cases mixtures of products where the only recognizable compounds are the scarcely soluble ammonium ester salts $\left[\mathrm{RCH}\left(\mathrm{NH}_{3}\right) \mathrm{COOR}^{\prime}\right]\left[\mathrm{NbF}_{6}\right]$. These might be formed as a consequence of some activation reaction or the adventitious presence of water. ${ }^{\mathbf{4 1}}$ We were able to isolate satisfactory yields of well defined coordination compounds only in two cases (Scheme 9).

Compound 9 can be viewed as a coordination compound resulting from the unsymmetrical rupture of the structure of $\mathrm{NbF}_{5}$ (a tetramer in the solid state ${ }^{17 a}$ ). ${ }^{\mathbf{1 3 c , 4 2}}$ The IR spectrum shows a strong absorption at $1648 \mathrm{~cm}^{-1}$, attributed to the stretching vibration of the $\mathrm{C}=\mathrm{O}$ bond belonging to the ester function. The $c a .100 \mathrm{~cm}^{-1}$ shift to lower wavenumbers is in agreement with the coordination of the carbonyl moiety to niobium. The shift of the absorptions due to the stretching of the amino group from $3380 \mathrm{~cm}^{-1}$ (in $\mathbf{8 k}$ ) to $3232 \mathrm{~cm}^{-1}$ (in 9) suggests that also the nitrogen atom is involved in the coordination to the metal centre. Accordingly, two low field ${ }^{1} \mathrm{H}$ NMR resonances have been found for the $\mathrm{NH}_{2}$ group in $\mathbf{9}(\delta=8.6$ and $7.0 \mathrm{ppm}, \mathrm{CDCl}_{3}$ solution). On the other hand, the same group

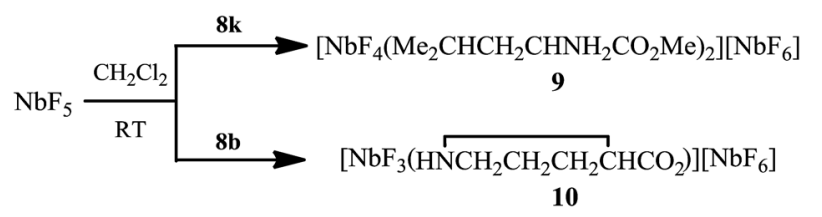

Scheme 9 Coordination compounds from the reactions of $\mathrm{NbF}_{5}$ with L-proline ethylester and L-leucine methylester.
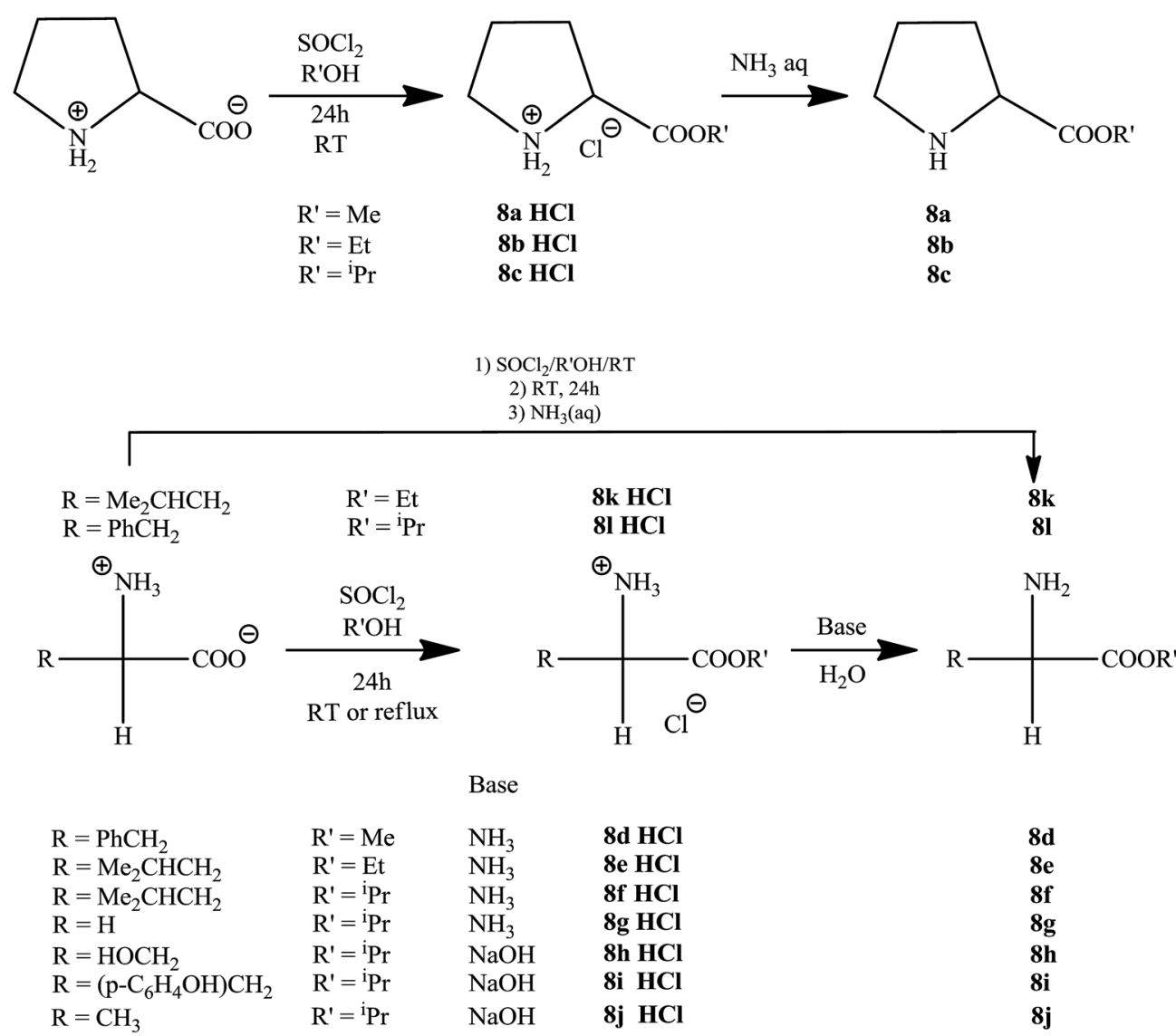

Scheme 8 Synthesis of $\alpha$-amino acid esters. 
gives raise to a singlet at $1.65 \mathrm{ppm}$ in the ${ }^{1} \mathrm{H}$ NMR spectrum of $8 \mathbf{k}$.

In addition, the ${ }^{19} \mathrm{~F}$ and ${ }^{93} \mathrm{Nb}$ NMR spectra (decet at $103 \mathrm{ppm}$ and septet at $-1553 \mathrm{ppm}$, respectively) are unequivocal fingerprints for the presence of the $\left[\mathrm{NbF}_{6}\right]^{-}$anion in solution. ${ }^{\mathbf{1 3 c , 4 2 , 4 3}}$

In conclusion, on considering the tendency of $\mathrm{NbF}_{5}$ to the unsymmetrical breaking of the $\mathrm{Nb}-\mathrm{F}$ bridges, with formation of $\left[\mathrm{NbF}_{4}\right]^{+}$cations and $\left[\mathrm{NbF}_{6}\right]^{-}$anions, ${ }^{42}$ analytical and spectroscopic data suggest that 9 is a salt containing an octacoordinate $\left[\mathrm{NbF}_{4}\left(\mathrm{Me}_{2} \mathrm{CHCH}_{2} \mathrm{CHNH}_{2} \mathrm{CO}_{2} \mathrm{Me}\right)_{2}\right]^{+}$cation, comprising two $\mathrm{O}, \mathrm{N}$-ligated $\alpha$-amino acid esters, and a $\left[\mathrm{NbF}_{6}\right]^{-}$anion. The coordination number of the cation was confirmed by DFT calculations, being six-coordinate geometries less stable by more than $30 \mathrm{kcal} \mathrm{mol}^{-1}$. The optimized geometry is shown in Fig. 5. DFT calculations with dichloromethane as implicit solvent also indicated that the $\left[\mathrm{NbF}_{4}\left(\mathrm{Me}_{2} \mathrm{CHCH}_{2} \mathrm{CHNH}_{2} \mathrm{CO}_{2}\right.\right.$ $\left.\mathrm{Me})_{2}\right]\left[\mathrm{NbF}_{6}\right]$ salt is slightly more stable compared to its neutral isomer $\mathrm{NbF}_{5}\left(\mathrm{Me}_{2} \mathrm{CHCH}_{2} \mathrm{CHNH}_{2} \mathrm{CO}_{2} \mathrm{Me}\right)$. The metal centre in this last species should be eight-coordinated, the $\alpha$-amino acid ester behaving as N,O-donor chelating ligand (Fig. S4 $\dagger$ ).

It worth noting that the majority of coordination complexes containing $\alpha$-amino acid ester ligands are based on late transition metals (Ru, Os, Co, Rh, Pt, Zn). ${ }^{44}$ Only few examples are known with group 6 elements ${ }^{45}$ and also derivatives of group 4 and group 5 metals are very rare.

The reaction of $\mathrm{NbF}_{5}$ with L-proline ethyl ester, $\mathbf{8 b}$, revealed a different outcome, and $\mathbf{1 0}$ was obtained under the same conditions employed for $\mathrm{NbF}_{5} / \mathbf{8 k}$. The use of $\mathbf{N b} / \mathbf{8 b}$ molar ratio $=2$ afforded 10 with the best yield (Scheme 9). Ethyl fluoride was NMR identified as a co-product of the reaction performed in $\mathrm{CD}_{2} \mathrm{Cl}_{2}$ in a closed tube, while L-proline was recovered after hydrolysis of the reaction mixture. These experimental facts support the presence in $\mathbf{1 0}$ of a carboxylato moiety originated from the cleavage of the ester function.

Compound $\mathbf{1 0}$ is a colourless solid whose salient spectroscopic features are two IR bands at $3381 \mathrm{~cm}^{-1}(\mathrm{~N}-\mathrm{H})$ and 1636 $\mathrm{cm}^{-1}(\mathrm{C}=\mathrm{O})$, and ${ }^{1} \mathrm{H}$ and ${ }^{19} \mathrm{~F}$ NMR resonances at $11.77 \mathrm{ppm}$ $(\mathrm{NH})$ and $100.9 \mathrm{ppm}\left(\left[\mathrm{NbF}_{6}\right]^{-}\right)$, respectively. These data suggest a bidentate $\mathrm{N}, \mathrm{O}$-coordination of the $\alpha$-amino carboxylate ligand. Dinuclear geometries with the $\alpha$-amino acidate as bridging

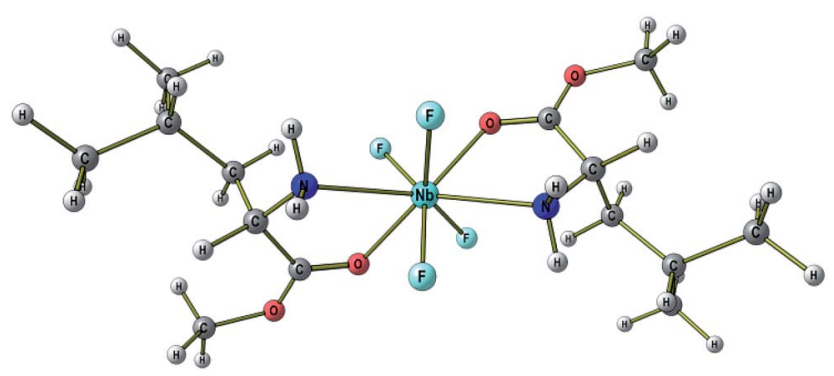

Fig. 5 DFT-optimized geometry of the cation of 9 (C-PCM/M06 calculations). Selected computed bond lengths $(\AA \AA)$ : $\mathrm{Nb}-\mathrm{O} 2.273$, 2.273; Nb-N 2.364, 2.364; Nb-F 1.900, 1.900, 1.900, 1.900; C-O(Nb) 1.234, 1.234; $\mathrm{C}-\mathrm{O}(\mathrm{Me}) 1.303,1.303 ; \mathrm{N}-\mathrm{H} 1.019,1.019,1.019,1.020$. Selected computed angles $\left(^{\circ}\right)$ : $\mathrm{O}-\mathrm{Nb}-\mathrm{N} 68.3,68.3 ; \mathrm{O}-\mathrm{Nb}-\mathrm{O}$ 135.0; $\mathrm{N}-\mathrm{Nb}-\mathrm{N}$ 132.3; C-O-Nb 123.3, 123.3. ligand were ruled out by DFT calculations. The optimized geometry of the cation of $\mathbf{1 0}$ is depicted in Fig. 6 (see also Fig. S5 given as ESI $\dagger$ ).

We extended the present study to the interaction of $\alpha$-amino acid esters with the heavier niobium pentahalides. These reactions led to complicated mixtures of metal products, with presumable activation of the organic substrates. Only in a few cases, all involving the metal pentachlorides, a clean reaction pathway was observed (Scheme 10).

All the identified products, $\mathbf{1 1 a}-\mathbf{d}$ and $\mathbf{1 2}$, are colourless to pale yellow solids, being scarcely soluble in organic solvents. Spectroscopic considerations discussed for $\mathbf{1 0}$ are valid also for 11a-d, thus suggesting the bidentate N,O coordination of two $\alpha$ amino acid ester ligands to the same metal centre within a cation. The presence of the $\left[\mathrm{NbCl}_{6}\right]^{-}$anion in $11 a-c$ is the consequence of unsymmetrical cleavage of the dinuclear $\mathrm{NbCl}_{5}$ structure, ${ }^{13 c, 33,46}$ and was unambiguously evidenced by a sharp ${ }^{93} \mathrm{Nb}$ NMR resonance occurring in the interval 4-13 ppm. ${ }^{13 c, 33}$

DFT calculations were carried out on the cation of 11a, considering either one or two $\alpha$-amino acid esters in the niobium sphere. The coordination of another equivalent of the $\alpha$-amino acid ester to $\left[\mathrm{NbCl}_{4}\left(\mathrm{Me}_{2} \mathrm{CHCH}_{2} \mathrm{CHNH}_{2} \mathrm{CO}_{2} \mathrm{Me}\right)\right]^{+}$ resulted a favourable process, being the associated $\Delta \mathrm{G}$ variation

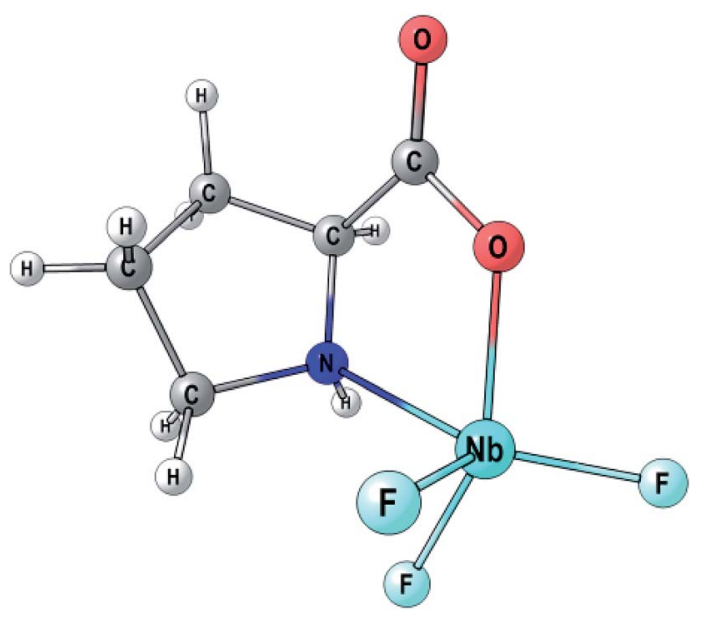

Fig. 6 DFT-optimized geometry of the cation of 10 (C-PCM/M06 calculations). Selected computed bond lengths ( $\AA$ ): $\mathrm{Nb}-\mathrm{O} 1.902 ; \mathrm{Nb}-$ $\mathrm{N} 2.243 ; \mathrm{Nb}-\mathrm{F} 1.833,1.835,1.857 ; \mathrm{C}-\mathrm{O} 1.365 ; \mathrm{C}=\mathrm{O} 1.192 ; \mathrm{N}-\mathrm{H} 1.022$. Selected computed angles $\left({ }^{\circ}\right)$ : $\mathrm{O}-\mathrm{Nb}-\mathrm{N}$ 73.5; $\mathrm{O}-\mathrm{Nb}-\mathrm{F}$ 97.7, 97.7, 147.3; C-O-Nb 131.0.

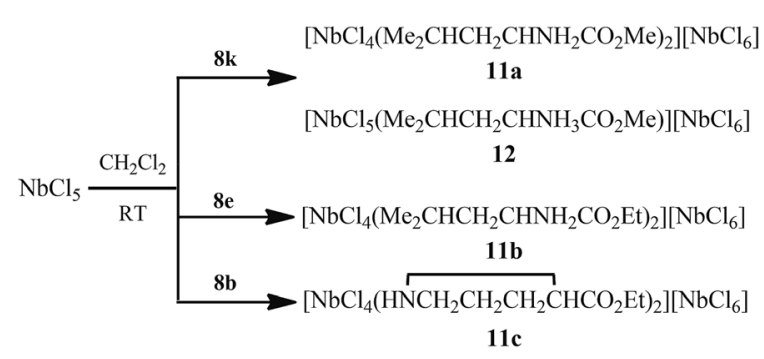

Scheme 10 Synthesis of niobium pentachloride derivatives of $\alpha$ amino acid esters. 
around $-25 \mathrm{kcal} \mathrm{mol}^{-1}$. The DFT-optimized geometry of $\left[\mathrm{NbCl}_{4}\left(\mathrm{Me}_{2} \mathrm{CHCH}_{2} \mathrm{CHNH}_{2} \mathrm{CO}_{2} \mathrm{Me}\right)_{2}\right]^{+}$is represented in Fig. 7.

A crop of X-ray quality crystals of $\mathbf{1 2}$ was obtained directly from the reaction mixture after separation from 11a. Compound $\mathbf{1 2}$ differs from the previous compounds as far as the solubility is concerned. Once isolated in the solid state, it does not dissolve again in common organic solvents.

Compound 12 consists of an ionic packing of $\left[\mathrm{NbCl}_{5}(-\right.$ $\left.\left.\left.\mathrm{CH}_{3}\right)_{2} \mathrm{CHCH}_{2} \mathrm{CHNH}_{3} \mathrm{CO}_{2} \mathrm{Me}\right)\right]^{+}$cations and $\left[\mathrm{NbCl}_{6}\right]^{-}$anions. The cation is represented in Fig. 8, and the related bonding parameters are reported in Table 3. A view of the structure of the anion is given in Fig. S6, $\uparrow$ the relevant bonding parameters being collected in Table $\mathrm{S} 2 \mathrm{~A} . \dagger \mathrm{H}$-bonds between the $\mathrm{NH}_{3}$-group of the cation and the chlorides of $\left[\mathrm{NbCl}_{6}\right]^{-}$are present within the crystals (see Table $\mathrm{S} 2 \mathrm{~B} \uparrow$ for details). Compound 12 crystallizes in the chiral space group $P 2_{1}$ and the $\mathrm{C}(2)$ atom of the $\alpha$ amino acid ester ligand displays $S$ absolute configuration.

The source of protonation leading to $\mathbf{1 2}$ is not clear, being possibly the result of some activation of the organic reactant

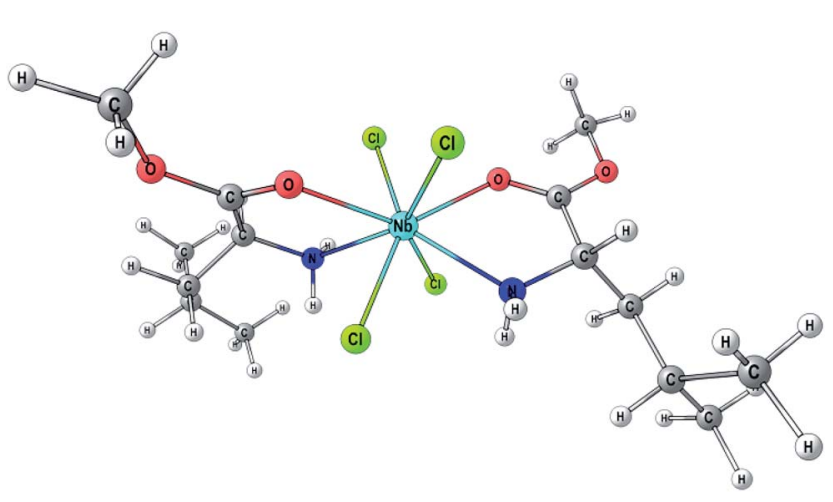

Fig. 7 DFT-optimized geometry of the cation of 11a (C-PCM/M06 calculations). Selected computed bond lengths (Å): Nb-O 2.261, 2.266; Nb-N 2.377, 2.381; Nb-Cl 2.380, 2.382, 2.413, 2.414; $\mathrm{C}-\mathrm{O}(\mathrm{Nb})$ 1.236, 1.237; $\mathrm{C}-\mathrm{O}(\mathrm{Me}) 1.294,1.294 ; \mathrm{N}-\mathrm{H}$ 1.020, 1.021, 1.020, 1.021. Selected computed angles $\left({ }^{\circ}\right)$ : O-Nb-N 68.4, 68.4; O-Nb-O 136.2; $\mathrm{N}-\mathrm{Nb}-\mathrm{N}$ 132.9; $\mathrm{C}-\mathrm{O}-\mathrm{Nb}$ 123.7, 123.8.

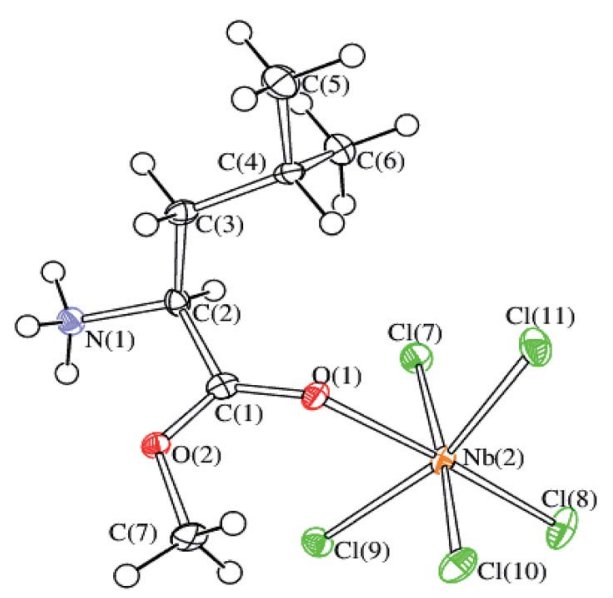

Fig. 8 ORTEP drawing of the $\left.\left[\mathrm{NbCl}_{5}\left(\mathrm{CH}_{3}\right)_{2} \mathrm{CHCH}_{2} \mathrm{CHNH}_{3} \mathrm{CO}_{2} \mathrm{Me}\right)\right]^{+}$ cation in 12. The $\left[\mathrm{NbCl}_{6}\right]^{-}$anion is reported in Fig. S6.† Displacement ellipsoids are at the $50 \%$ probability level. promoted by the strongly acidic niobium chloride. Nevertheless, the occurrence of fortuitous hydrolysis might play some role and should not be ruled out.

12 represents the second crystallographically characterized example where a cationic $\alpha$-amino acid ester is coordinated to any metal centre, and the first one where the coordination occurs via oxygen. In fact, previous to this work, only the structure of a $\mathrm{Ru}(\mathrm{II})$ complex containing a $\eta^{6}$-bonded L-phenylalaninium methyl ester was reported. ${ }^{47}$ More commonly, $\alpha$ amino acid esters act as ligands in the neutral form $\mathrm{RCHNH}_{2}$ $\mathrm{CO}_{2} \mathrm{R}^{\prime}$, via the $\mathrm{N}$-atom or both $\mathrm{N}$ and $\mathrm{O} .^{44,45}$

We moved to study the reaction of $\mathrm{NbCl}_{5}$ with L-serine isopropylester, $\mathbf{8 h}$, i.e. a $\boldsymbol{\alpha}$-amino acid ester bearing a peripheral $\mathrm{OH}$ group and potentially acting as a pincer ligand. The $1: 1$ reaction of $\mathrm{NbCl}_{5}$ and $\mathbf{8 h}$ in refluxing chloroform led to the formation of $\mathrm{NbCl}_{3}\left(\mathrm{OCHCH}_{2} \mathrm{NHCOO}^{\mathrm{i}} \mathrm{Pr}\right), 13$, as a colourless precipitate. The $\nu(\mathrm{C}=\mathrm{O})$ stretching band in $13\left(1732 \mathrm{~cm}^{-1}\right)$ is only slightly shifted respect to $\mathbf{8 h}\left(1728 \mathrm{~cm}^{-1}\right)$, thus indicating that the ester group is not involved in coordination.

Table 3 Selected bond distances $(\AA)$ and angles $\left(^{\circ}\right)$ for the $\left[\mathrm{NbCl}_{5}(-\right.$ $\left.\left.\left.\mathrm{CH}_{3}\right)_{2} \mathrm{CHCH}_{2} \mathrm{CHNH}_{3} \mathrm{CO}_{2} \mathrm{Me}\right)\right]^{+}$cation in 12 . The data relative to the $\left[\mathrm{NbCl}_{6}\right]^{-}$anion are reported in Tables S2A and S2B

\begin{tabular}{llll}
\hline $\mathrm{Nb}(2)-\mathrm{Cl}(7)$ & $2.3555(9)$ & $\mathrm{Nb}(2)-\mathrm{Cl}(8)$ & $2.2641(10)$ \\
$\mathrm{Nb}(2)-\mathrm{Cl}(9)$ & $2.3318(10)$ & $\mathrm{Nb}(2)-\mathrm{Cl}(10)$ & $2.3250(10)$ \\
$\mathrm{Nb}(2)-\mathrm{Cl}(11)$ & $2.2918(9)$ & $\mathrm{Nb}(2)-\mathrm{O}(1)$ & $2.209(2)$ \\
$\mathrm{C}(1)-\mathrm{O}(1)$ & $1.231(4)$ & $\mathrm{C}(1)-\mathrm{O}(2)$ & $1.291(4)$ \\
$\mathrm{C}(7)-\mathrm{O}(2)$ & $1.473(3)$ & $\mathrm{C}(1)-\mathrm{C}(2)$ & $1.499(4)$ \\
$\mathrm{C}(2)-\mathrm{N}(1)$ & $1.506(4)$ & $\mathrm{C}(2)-\mathrm{C}(3)$ & $1.534(4)$ \\
$\mathrm{Cl}(7)-\mathrm{Nb}(2)-\mathrm{Cl}(10)$ & $174.26(3)$ & $\mathrm{Cl}(9)-\mathrm{Nb}(2)-\mathrm{Cl}(11)$ & $163.09(3)$ \\
$\mathrm{Cl}(8)-\mathrm{Nb}(2)-\mathrm{O}(1)$ & $177.18(6)$ & $\mathrm{Nb}(2)-\mathrm{O}(1)-\mathrm{C}(1)$ & $145.2(2)$ \\
$\mathrm{O}(1)-\mathrm{C}(1)-\mathrm{O}(2)$ & $125.5(3)$ & $\mathrm{O}(1)-\mathrm{C}(1)-\mathrm{C}(2)$ & $121.0(3)$ \\
$\mathrm{O}(2)-\mathrm{C}(1)-\mathrm{C}(2)$ & $113.5(3)$ & $\mathrm{C}(1)-\mathrm{C}(2)-\mathrm{C}(3)$ & $112.3(3)$ \\
$\mathrm{C}(1)-\mathrm{C}(2)-\mathrm{N}(1)$ & $109.4(2)$ & $\mathrm{N}(1)-\mathrm{C}(2)-\mathrm{C}(3)$ & $108.4(3)$
\end{tabular}

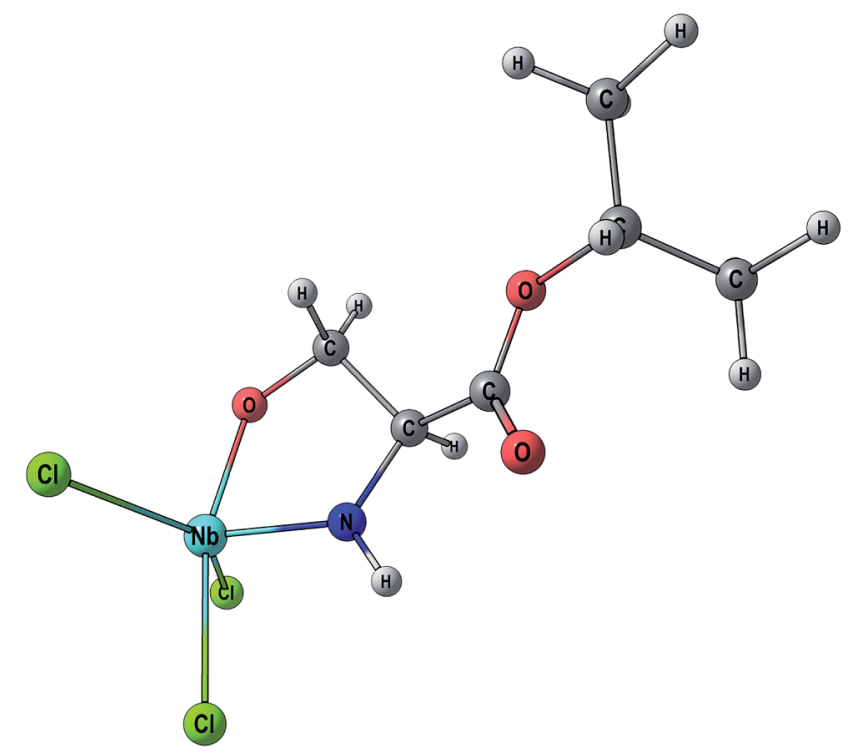

Fig. 9 DFT-optimized geometry of 13 (C-PCM/M06 calculations). Selected computed bond lengths (Å): $\mathrm{Nb}-\mathrm{O} 1.873 ; \mathrm{Nb}-\mathrm{N} 1.943 ; \mathrm{Nb}-$ $\mathrm{Cl} 2.359,2.368,2.389 ; \mathrm{N}-\mathrm{H}$ 1.019. Selected computed angles $\left(^{\circ}\right)$ : O$\mathrm{Nb}-\mathrm{N} 76.0 ; \mathrm{O}-\mathrm{Nb}-\mathrm{Cl}$ 93.3, 96.7, 157.8; $\mathrm{N}-\mathrm{Nb}-\mathrm{Cl} 82.0,109.3,110.0$. 
Compound 13 showed a single set of signals in ${ }^{1} \mathrm{H}$ and ${ }^{13} \mathrm{C}$ NMR spectra (in $\mathrm{CD}_{3} \mathrm{CN}$ ); ${ }^{1} \mathrm{H}$ resonances are shifted to higher ppm values with respect to $\mathbf{8 h}$ [most notably $\delta(\mathrm{NH})$ from $2.6 \mathrm{ppm}$ in $\mathbf{8 h}$ to $7.0 \mathrm{ppm}$ in $\mathbf{1 3}$, while ${ }^{13} \mathrm{C}$ resonances are shifted to lower ppm values $[$ e.g., $\delta(\mathrm{CO})$ from $175 \mathrm{ppm}$ in $\mathbf{8 h}$ to $167 \mathrm{ppm}$ in 13].

At variance to the other $\alpha$-amino acid ester complexes of niobium in this work, compound $\mathbf{1 3}$ is a neutral species in solution with a single ${ }^{93} \mathrm{Nb}$ resonance at $-493 \mathrm{ppm}$. DFT calculations suggest a mononuclear structure (Fig. 9) as the most probable geometry. A positive Gibbs energy variation (about $3.5 \mathrm{kcal} \mathrm{mol}^{-1}$ ) is accompanied to the dimerization of this species to the dinuclear form (see Fig. $\mathrm{S} 7$ and $\mathrm{S} 8 \dagger$ for more details).

We could not cleanly isolate metal products from $\mathrm{MBr}_{5} / \alpha$ amino acid ester $(\mathrm{M}=\mathrm{Nb}, \mathrm{Ta})$. However, NMR investigations outlined the release of ethyl bromide from L-proline ethylester, in the presence of $\mathrm{MBr}_{5}$ (see Experimental for details).

\section{Conclusions}

The reactions of $\mathrm{TiCl}_{4}$ with a series of $\alpha$-amino acids do not proceed with $\mathrm{HCl}$ release, in spite of the Lewis acidic character of the metal centre, and afford dinuclear coordination compounds containing zwitterionic ligands. Deprotonation of the ammonium function may be easily promoted by the addition of triethylamine, resulting in a modification of the coordination fashion of the $\alpha$-amino acidic frame. On the other hand, the interaction of $\mathrm{L}$-proline with $\mathrm{NbCl}_{5} / \mathrm{NHEt}_{2}$ has provided the first example of $\mathrm{C}-\mathrm{C}$ bond forming selfcondensation of a $\alpha$-amino acid, although in modest yield. The overall transformation may be regarded as a Lewis acid induced intramolecular redox reaction, in which the carboxylate group is reduced and the pyrrolidine ring is oxidized. The combination of $\mathrm{NbCl}_{5}$ or $\mathrm{WCl}_{6}$ with the chlorinating power of $\mathrm{PCl}_{5}$ has been exploited to develop a simple synthetic method affording isolable salts of otherwise unstable $\alpha$-ammonium acylchloride cations. $\alpha$-Amino acid esters usually behave as bidentate $\mathrm{O}, \mathrm{N}$-ligands towards niobium and tantalum pentahalides, however activation of the ester function with release of alkyl halides has been observed in some cases.

\section{Experimental}

\section{General}

Warning: all the metal products reported in this paper are highly moisture-sensitive, thus rigorously anhydrous conditions were required for the reaction and crystallization procedures. The reaction vessels were oven dried at $140{ }^{\circ} \mathrm{C}$ prior to use, evacuated $\left(10^{-2} \mathrm{mmHg}\right)$ and then filled with argon. $\mathrm{TiCl}_{4}$, $\mathrm{NbX}_{5}(\mathrm{X}=\mathrm{F}, \mathrm{Cl}), \mathrm{PCl}_{5}$ and $\mathrm{WCl}_{6}$ were purchased from Strem $(>98 \%$ purity) and stored in sealed tubes under argon atmosphere. $\mathrm{NbBr}_{5}$ and $\mathrm{TaBr}_{5}$ were prepared according to literature procedures and stored under argon atmosphere. ${ }^{48}$ Once isolated, the metal products were conserved in sealed glass tubes under argon. The organic reactants were commercial products (Sigma-Aldrich) stored under argon atmosphere as received.
Solvents (Sigma-Aldrich) were distilled before use from appropriate drying agents. Chromatographic purification of organic products was carried out on columns of deactivated alumina ( $4 \% \mathrm{w} / \mathrm{w}$ water). Infrared spectra were recorded at $298 \mathrm{~K}$ on a FT IR-Perkin Elmer Spectrometer, equipped with a UATR sampling accessory. NMR spectra were recorded at $293 \mathrm{~K}$ on a Bruker Avance II DRX400 instrument equipped with a BBFO broadband probe. The chemical shifts for ${ }^{1} \mathrm{H}$ and ${ }^{13} \mathrm{C}$ were referenced to the non-deuterated aliquot of the solvent; the chemical shifts for ${ }^{93} \mathrm{Nb}$ were referenced to external $\left[\mathrm{NEt}_{4}\right]\left[\mathrm{NbCl}_{6}\right]$; the chemical shifts for ${ }^{19} \mathrm{~F}$ were referenced to external $\mathrm{CFCl}_{3}$. Conductivity measurement was carried out using an Eutech Con 700 instrument (cell constant $=1.0 \mathrm{~cm}^{-1}$ ). ${ }^{49}$ Magnetic susceptibilities (reported per W atom) were measured on solid samples at $298 \mathrm{~K}$ with a Magway MSB Mk1 magnetic susceptibility balance (Sherwood Scientific Ltd). Diamagnetic corrections were introduced according to König. ${ }^{50}$ Carbon, hydrogen and nitrogen analyses were performed on a Carlo Erba mod. 1106 instrument. The chloride/bromide content was determined by the Mohr method ${ }^{51}$ on solutions prepared by dissolution of the solids in aqueous $\mathrm{KOH}$ and heated at boiling temperature for 72 hours, followed by cooling to room temperature and addition of $\mathrm{HNO}_{3}$ up to neutralization. Titanium, niobium and tantalum were analyzed, respectively, as $\mathrm{TiO}_{2}$ and $\mathrm{M}_{2} \mathrm{O}_{5}(\mathrm{M}=\mathrm{Nb}, \mathrm{Ta})$, obtained by hydrolysis of the samples followed by calcination in a platinum crucible.

Reactions of $\mathrm{TiCl}_{4}$ with $\alpha$-amino acids: synthesis of $\mathrm{TiCl}_{4}(\mathrm{aa})$ (aa = L-proline, 1a; L-phenylalanine, 1b; sarcosine, 1c; $\mathrm{N}, \mathrm{N}$ dimethylglycine, 1d)

General procedure. A suspension of the appropriate $\alpha$-amino acid $(1.50 \mathrm{mmol})$ in $\mathrm{CH}_{2} \mathrm{Cl}_{2}$ (ca. $\left.15 \mathrm{~mL}\right)$ was treated with a solution $\left(100 \mathrm{mg} \mathrm{mL}^{-1}\right)$ of $\mathrm{TiCl}_{4}(1.50 \mathrm{mmol})$ in heptane. The mixture was stirred at room temperature overnight, then hexane (ca. $30 \mathrm{~mL}$ ) was added. The precipitate was separated and dried in vacuo.

$\mathrm{TiCl}_{4}$ (L-proline), 1a. Yellow solid, yield $321 \mathrm{mg}$ (70\%). Anal. calcd for $\mathrm{C}_{5} \mathrm{H}_{9} \mathrm{Cl}_{4} \mathrm{NO}_{2} \mathrm{Ti}: \mathrm{C}, 19.70 ; \mathrm{H}, 2.98 ; \mathrm{N}, 4.60 ; \mathrm{Cl}, 46.52 ; \mathrm{Ti}$, 15.70. Found: C, 19.39; H, 3.09; N, 4.52; Cl, 45.88; Ti, 15.89. IR (solid state): $\nu=3219 \mathrm{mw}, 2962 \mathrm{w}, 1570 \mathrm{~m}, 1544 \mathrm{vs}, 1441 \mathrm{vs}$, $1367 \mathrm{~m}, 1331 \mathrm{~ms}, 1260 \mathrm{~m}, 1081 \mathrm{~m}, 1031 \mathrm{~ms}, 798 \mathrm{~s} \mathrm{~cm}^{-1} .{ }^{1} \mathrm{H}$ NMR ( $\left.\mathrm{CD}_{3} \mathrm{CN}\right): \delta=7.46,7.15\left(\mathrm{br}, 2 \mathrm{H}, \mathrm{NH}_{2}\right) ; 4.53(\mathrm{br}, 1 \mathrm{H}, \mathrm{NCH})$; 3.54, 3.45, 2.42, 2.20, 2.06 (br, 6H, $\left.\mathrm{CH}_{2}\right) \mathrm{ppm} .{ }^{13} \mathrm{C} \mathrm{NMR}\left(\mathrm{CD}_{3} \mathrm{CN}\right)$ : $\delta=176.1$ (OCO); $61.6(\mathrm{CH}) ; 47.6,28.6,23.7\left(\mathrm{CH}_{2}\right) \mathrm{ppm}$.

$\mathrm{TiCl}_{4}$ (L-phenylalanine), $\mathbf{1 b}$. Light orange solid, yield $388 \mathrm{mg}$ (73\%). Anal. calcd for $\mathrm{C}_{9} \mathrm{H}_{11} \mathrm{Cl}_{4} \mathrm{NO}_{2}$ Ti: C, 30.46; $\mathrm{H}, 3.12$; N, 3.95; Cl, 39.96; Ti, 13.49. Found: C, 30.60; H, 3.02; N, 4.13; Cl, 39.40; Ti, 13.28. IR (solid state): $\nu=3030 \mathrm{~m}$-br, $1600 \mathrm{~m}, 1558 \mathrm{vs}, 1445$ vs-br, $1336 \mathrm{~m}, 1047 \mathrm{w}, 744 \mathrm{~m}, 698 \mathrm{~ms} \mathrm{~cm}^{-1} .{ }^{1} \mathrm{H}$ NMR $\left(\mathrm{CD}_{3} \mathrm{CN}\right)$ : $\delta=7.39-7.30,6.98\left(8 \mathrm{H}, \mathrm{Ph}+\mathrm{NH}_{3}\right) ; 4.46(\mathrm{~m}, 1 \mathrm{H}, \mathrm{CH}) ; 3.28(\mathrm{~m}$, $\left.2 \mathrm{H}, \mathrm{CH}_{2}\right)$ ppm. ${ }^{13} \mathrm{C} \mathrm{NMR}\left(\mathrm{CD}_{3} \mathrm{CN}\right): \delta=170.0$ (OCO); 134.1 (ipso$\mathrm{Ph}) ; 129.8,129.2,127.9\left(\mathrm{C}_{6} \mathrm{H}_{5}\right) ; 61.8(\mathrm{CH}) ; 35.3\left(\mathrm{CH}_{2}\right) \mathrm{ppm}$.

$\mathrm{TiCl}_{4}$ (sarcosine), 1c. Yellow solid, yield $448 \mathrm{mg}$ (78\%). Anal. calcd for $\mathrm{C}_{3} \mathrm{H}_{7} \mathrm{Cl}_{4} \mathrm{NO}_{2} \mathrm{Ti}$ : C, 12.93; H, 2.53; N, 5.02; Cl, 50.87; Ti, 17.17. Found: C, 13.02; H, 2.43; N, 4.98; Cl, 36.23; Ti, 12.80. IR (solid state): $\nu=3185 \mathrm{~m}, 2930 \mathrm{vw}, 2810 \mathrm{vw}, 1575 \mathrm{~ms}, 1561 \mathrm{vs}$, 
$1454 \mathrm{~s}, 1429 \mathrm{w}, 1409 \mathrm{~ms}, 937 \mathrm{w}, 792 \mathrm{~s}, 689 \mathrm{~m}-\mathrm{w} \mathrm{cm}{ }^{-1} \cdot{ }^{1} \mathrm{H}$ NMR $\left(\mathrm{CD}_{3} \mathrm{CN}\right): \delta=7.26,7.00$ (br, 2H, $\mathrm{NH}_{2}$ ); 4.03 (br, $2 \mathrm{H}, \mathrm{CH}_{2}$ ); 2.81 (br, $3 \mathrm{H}, \mathrm{CH}_{3}$ ) ppm.

$\mathrm{TiCl}_{4}(\mathrm{~N}, \mathrm{~N}$-dimethylglycine), 1d. Yellow solid, yield $312 \mathrm{mg}$ (71\%). Anal. calcd for $\mathrm{C}_{4} \mathrm{H}_{9} \mathrm{Cl}_{4} \mathrm{NO}_{2} \mathrm{Ti}$ : C, 16.41; $\mathrm{H}, 3.10 ; \mathrm{N}, 4.78$; Cl, 48.43; Ti, 16.35. Found: C, 16.29; H, 3.17; N, 4.91; Cl, 48.26; Ti, 16.57. IR (solid state): $\nu=3091 \mathrm{~m}-\mathrm{w}, 2983 \mathrm{w}, 1573 \mathrm{vs}, 1438 \mathrm{~s}$, $1401 \mathrm{~m}, 1364 \mathrm{~s}, 1324 \mathrm{~m}, 1142 \mathrm{~m}-\mathrm{w}, 932 \mathrm{~m}-\mathrm{w}, 857 \mathrm{~m}, 716 \mathrm{~m} \mathrm{~cm}^{-1}$. ${ }^{1} \mathrm{H}$ NMR $\left(\mathrm{CD}_{3} \mathrm{CN}\right): \delta=7.7(\mathrm{br}, 1 \mathrm{H}, \mathrm{NH}) ; 4.09\left(\mathrm{br}, 2 \mathrm{H}, \mathrm{CH}_{2}\right) ; 3.01$ (br, $6 \mathrm{H}, \mathrm{CH}_{3}$ ) ppm.

\section{Reactions of $\mathrm{TiCl}_{4}$ with $\alpha$-amino acid/ $\mathrm{NEt}_{3}$ : synthesis of $\left[\mathrm{NHEt}_{3}\right]\left[\mathrm{TiCl}_{4}(\mathrm{aa})\right]$ (aa = L-phenylalanine, 2a; $N, N$ - dimethylphenylalanine, $2 b$ )}

General procedure. A suspension of the appropriate $\alpha$-amino acid $(1.00 \mathrm{mmol})$ in $\mathrm{CH}_{2} \mathrm{Cl}_{2}$ (ca. $10 \mathrm{~mL}$ ) was treated with a solution $\left(100 \mathrm{mg} \mathrm{mL}{ }^{-1}\right)$ of $\mathrm{TiCl}_{4}(1.00 \mathrm{mmol})$ in heptane. The mixture was stirred at room temperature overnight, then hexane (ca. $30 \mathrm{~mL}$ ) was added. The liquors were eliminated with a syringe, then $\mathrm{CH}_{2} \mathrm{Cl}_{2}(20 \mathrm{~mL})$ and $\mathrm{NEt}_{3}(1.00 \mathrm{mmol})$ were added in the order given. The mixture was allowed to stir for $5 \mathrm{~h}$, then hexane $(30 \mathrm{~mL})$ was added. The resulting precipitate was separated and dried in vacuo.

[NHEt 3$]\left[\mathrm{TiCl}_{4}(\mathrm{~L}\right.$-phenylalanine $\left.)\right]$, 2a. Light brown solid, yield $297 \mathrm{mg}$ (65\%). Anal. calcd for $\mathrm{C}_{15} \mathrm{H}_{26} \mathrm{Cl}_{4} \mathrm{~N}_{2} \mathrm{O}_{2} \mathrm{Ti}: \mathrm{C}, 39.50 ; \mathrm{H}$, 5.75; N, 6.14; Cl, 39.50; Ti, 10.50. Found: C, 39.33; H, 5.87; N, 6.16; Cl, 39.19; Ti, 10.61. IR (solid state): $\nu=3306 \mathrm{w}, 3240 \mathrm{w}-\mathrm{br}$, 2984 w-br, 2675 w-br, 2488 w-br, 1691 vs, 1652 vs, 1568 s, 1454 s, $1228 \mathrm{~m}, 1099 \mathrm{~m}-\mathrm{s}, 1070 \mathrm{~m}-\mathrm{s}, 749 \mathrm{vs}, 702 \mathrm{~s} \mathrm{~cm}^{-1} .{ }^{1} \mathrm{H}$ NMR $\left(\mathrm{CD}_{2} \mathrm{Cl}_{2}\right): \delta=9.09(\mathrm{~s}, 1 \mathrm{H}, \mathrm{NH}) ; 7.39-7.30(5 \mathrm{H}, \mathrm{Ph}) ; 4.38(\mathrm{~m}, 1 \mathrm{H}$, $\mathrm{CH}$ ); 4.13, 3.62 (br, 2H, $\mathrm{NH}_{2}$ ); 3.26 (m, 6H, $\mathrm{NCH}_{2}$ ); 3.40, 3.17 (dd, $\left.2 \mathrm{H}, \mathrm{CH}_{2} \mathrm{Ph}\right) ; 1.40\left(\mathrm{t},{ }^{3} \mathrm{~J}_{\mathrm{HH}}=7.34 \mathrm{~Hz}, 9 \mathrm{H}, \mathrm{NCH}_{2} \mathrm{CH}_{3}\right) \mathrm{ppm} .{ }^{13} \mathrm{C}$ NMR ( $\mathrm{CD}_{2} \mathrm{Cl}_{2}$ ): $\delta=179.5$ (OCO); 135.9 (ipso-Ph); 129.4, 129.2, 127.5 (Ph); $61.7(\mathrm{CH}) ; 47.1 \quad\left(\mathrm{NCH}_{2}\right) ; 38.6 \quad\left(\mathrm{CH}_{2} \mathrm{Ph}\right) ; 9.0$ $\left(\mathrm{NCH}_{2} \mathrm{CH}_{3}\right)$ ppm.

$\left[\mathrm{NHEt}_{3}\right]\left[\mathrm{TiCl}_{4}(\mathrm{~L}-\mathrm{N}, \mathrm{N}\right.$-dimethylphenylalanine $\left.)\right], \mathbf{2 b}$. Yellow solid, yield $290 \mathrm{mg}$ (60\%). Anal. calcd for $\mathrm{C}_{17} \mathrm{H}_{30} \mathrm{Cl}_{4} \mathrm{~N}_{2} \mathrm{O}_{2}$ Ti: C, 42.18; H, 6.25; N, 5.79; Cl, 29.29; Ti, 9.89. Found: C, 42.36; H, 6.08; N, $5.65 ; \mathrm{Cl}, 29.41 ; \mathrm{Ti}, 9.72$. IR (solid state): $\nu=3260 \mathrm{w}-\mathrm{br}, 2963 \mathrm{w}-\mathrm{br}$, 2679 w-br, 1702 s, 1660 vs, 1581 vs, 1454 vs, 1260 m, 1012 s, $741 \mathrm{~s}, 699 \mathrm{~s} \mathrm{~cm}^{-1} .{ }^{1} \mathrm{H}$ NMR $\left(\mathrm{CD}_{2} \mathrm{Cl}_{2}\right): \delta=8.0(\mathrm{br}, 1 \mathrm{H}, \mathrm{NH}) ; 7.36-$ 7.26 (5H, Ph); 4.47 (m, 1H, CH); 3.32 (m, 6H, $\left.\mathrm{NCH}_{2}\right) ; 3.19,3.07$ $\left(\mathrm{m}, 2 \mathrm{H}, \mathrm{CH}_{2} \mathrm{Ph}\right) ; 2.95,2.73\left(\mathrm{~s}, 6 \mathrm{H}, \mathrm{NMe}_{2}\right) ; 1.42\left(\mathrm{t},{ }^{3} J_{\mathrm{HH}}=7.34 \mathrm{~Hz}\right.$, 9H, $\mathrm{NCH}_{2} \mathrm{CH}_{3}$ ) ppm. ${ }^{13} \mathrm{C} \mathrm{NMR}\left(\mathrm{CD}_{2} \mathrm{Cl}_{2}\right): \delta=178.8$ (OCO); 138.9 (ipso-Ph); 129.9, 129.2, 128.6, $126.6(\mathrm{Ph}) ; 75.6(\mathrm{CH}) ; 50.9,47.6$ $\left(\mathrm{NMe}_{2}\right) ; 47.5\left(\mathrm{NCH}_{2}\right) ; 30.8\left(\mathrm{CH}_{2} \mathrm{Ph}\right) ; 8.9\left(\mathrm{NCH}_{2} \mathrm{CH}_{3}\right) \mathrm{ppm}$.

\section{Reaction of $\mathrm{NbCl}_{5}$ with $\mathrm{L}$-proline/ $\mathrm{NH}^{\mathrm{i}} \mathrm{Pr}_{2}$ : synthesis and isolation of $\mathrm{Nb}_{2} \mathrm{Cl}_{8}\left\{\mu-\kappa^{2} \mathrm{O}, \kappa^{2} \mathrm{~N}-\left[\mathrm{CH}_{2} \mathrm{CH}_{2} \mathrm{CH}_{2} \mathrm{C}(\mathrm{N}) \mathrm{C}(\mathrm{O})\right]_{2}, 3\right.$, and $\left[\mathrm{NH}_{2}{ }^{\mathrm{i}} \mathbf{P r}_{2}\right]$ $\left[\mathrm{NbCl}_{6}\right], 4$}

$\mathrm{NbCl}_{5}(0.385 \mathrm{~g}, 1.42 \mathrm{mmol})$ and L-proline $(0.163 \mathrm{~g}, 1.42 \mathrm{mmol})$ were allowed to react in $\mathrm{CH}_{2} \mathrm{Cl}_{2}(20 \mathrm{~mL})$. The solution was repetitiously purged with nitrogen gas in order to remove released $\mathrm{HCl}$. After six hours, the yellowish mixture was treated with $\mathrm{NH}^{\mathrm{i}} \mathrm{Pr}_{2}(0.203 \mathrm{~mL}, 1.45 \mathrm{mmol})$, then the stirring was prolonged for additional $20 \mathrm{~min}$. The final dark-red mixture was filtered off in order to remove a minor amount of solid, layered with hexane and settled aside at $-30{ }^{\circ} \mathrm{C}$. Red crystals of 3 were recovered after $48 \mathrm{~h}$. Yield $56 \mathrm{mg}, 12 \%$. Anal. calcd for $\mathrm{C}_{10} \mathrm{H}_{12}$ $\mathrm{Cl}_{8} \mathrm{~N}_{2} \mathrm{Nb}_{2} \mathrm{O}_{2}$ : C, 18.15; $\mathrm{H}, 1.83 ; \mathrm{N}, 4.23 ; \mathrm{Cl}, 42.86$. Found: $\mathrm{C}$, 18.43; H, 1.63; N, 4.51; Cl, 43.12. IR (solid state): $\nu=1580 \mathrm{~m}-\mathrm{s}$ $\left(\nu_{\mathrm{C}=\mathrm{N}}\right), 1183 \mathrm{~m}-\mathrm{s}\left(\nu_{\mathrm{C}-\mathrm{O}}\right) \mathrm{cm}^{-1}$.

The mother liquors were dried in vacuo, hence the residue was dissolved into $\mathrm{CHCl}_{3}(10 \mathrm{~mL})$. The solution was layered with pentane and settled aside at $-30{ }^{\circ} \mathrm{C}$, thus 4 was isolated as a yellow-orange crystals after $48 \mathrm{~h}$. Yield $238 \mathrm{mg}, 40 \%$. Anal. calcd for $\mathrm{C}_{7} \mathrm{H}_{16} \mathrm{Cl}_{6} \mathrm{NNb}$ : C, 20.03; H, 3.84; N, 3.34; Cl, 50.67. Found: C, 19.84; H, 3.75; N, 3.20; Cl, 49.95. IR (solid state): $\nu=$ 3130 s-br, 3080 s-br, 2987 w-m, 1606 m, 1565 m, $1424 \mathrm{~m} \mathrm{~cm}^{-1}$. ${ }^{1} \mathrm{H}$ NMR $\left(\mathrm{CD}_{3} \mathrm{CN}\right): \delta=6.30(\mathrm{br}, 1 \mathrm{H}, \mathrm{NH}) ; 3.48(\mathrm{~m}, 2 \mathrm{H}, \mathrm{CH}) ; 1.31$ $(\mathrm{m}, 12 \mathrm{H}, \mathrm{Me}) \mathrm{ppm} .{ }^{13} \mathrm{C} \mathrm{NMR}\left(\mathrm{CD}_{3} \mathrm{CN}\right): \delta=47.7(\mathrm{CH}) ; 18.2$ (Me) ppm. ${ }^{93} \mathrm{Nb} \mathrm{NMR}\left(\mathrm{CD}_{3} \mathrm{CN}\right): \delta=-0.2\left(\Delta \nu \frac{1}{2}=95 \mathrm{~Hz}\right) \mathrm{ppm}$.

\section{Reactions of $\alpha$-amino acids with $\mathrm{PCl}_{5} / \mathrm{NbCl}_{5}$ : synthesis of} $\left[(\mathrm{R})(\mathrm{Me}) \mathbf{N H C H}\left(\mathrm{R}^{\prime}\right) \mathrm{C}(\mathrm{O}) \mathrm{Cl}\right]\left[\mathrm{NbCl}_{6}\right]\left(\mathrm{R}=\mathrm{Me}, \mathbf{R}^{\prime}=\mathrm{CH}_{2} \mathrm{Ph}, 5 \mathrm{a}\right.$; $\left.\mathbf{R}=\mathbf{R}^{\prime}=\mathbf{H}, \mathbf{5 b}\right)$

General procedure. A suspension of $\mathrm{PCl}_{5}(169 \mathrm{mg}, 0.81$ $\mathrm{mmol})$ and $\mathrm{NbCl}_{5}(220 \mathrm{mg}, 0.81 \mathrm{mmol})$ in $\mathrm{CH}_{2} \mathrm{Cl}_{2}(10 \mathrm{~mL})$ was stirred at room temperature for $2-3 \mathrm{~h}$. Then the appropriate $\alpha$-amino acid $(0.81 \mathrm{mmol})$ was added. The resulting mixture was stirred at room temperature for $2 \mathrm{~h}$. The solution was concentrated to 3-5 $\mathrm{mL}$, then it was layered with pentane and stored in the freezer $\left(-30^{\circ} \mathrm{C}\right)$ for one week. A crop of crystalline material was collected and then stored at $-30{ }^{\circ} \mathrm{C}$. By slow evaporation of the crystallization solutions under inert atmosphere, few crystals of $\left[\mathrm{PhCH}_{2}=\mathrm{NMe}_{2}\right]\left[\mathrm{NbCl}_{6}\right]$ and $\mathrm{NbCl}_{5}\left(\mathrm{O}=\mathrm{PCl}_{3}\right)$, 6, were obtained from $\mathrm{PCl}_{5} / \mathrm{NbCl}_{5} / \mathrm{L}-\mathrm{N}, \mathrm{N}$-dimethylphenylalanine and $\mathrm{PCl}_{5} / \mathrm{NbCl}_{5} /$ sarcosine, respectively.

$\left[\mathrm{Me}_{2} \mathrm{NHCH}\left(\mathrm{CH}_{2} \mathrm{Ph}\right) \mathrm{C}(\mathrm{O}) \mathrm{Cl}\right]\left[\mathrm{NbCl}_{6}\right]$, 5a. Orange solid, yield $214 \mathrm{mg}(47 \%)$ from $\mathrm{PCl}_{5} / \mathrm{NbCl}_{5} / \mathrm{L}-\mathrm{N}, \mathrm{N}$-dimethylphenylalanine. Anal. calcd for $\mathrm{C}_{11} \mathrm{H}_{15} \mathrm{Cl}_{7} \mathrm{NNbO}$ : C, 25.49; $\mathrm{H}, 2.92 ; \mathrm{N}, 2.70 ; \mathrm{Cl}$, 47.88; Nb, 17.92. Found: C, 25.23; H, 2.80; N, 2.67; Cl, 47.60; Nb, 18.10. IR (solid state): $\nu=3087 \mathrm{w}-\mathrm{m}, 3029 \mathrm{w}, 2939 \mathrm{w}, 1767 \mathrm{vs}$ $\left(\nu_{\mathrm{C}=\mathrm{O}}\right), 1460 \mathrm{~s}, 1440 \mathrm{~m}, 1411 \mathrm{w}, 1374 \mathrm{w}, 1340 \mathrm{w}, 1287 \mathrm{w}, 1198 \mathrm{w}$, 1172 w, 1138 w, 1078 w, 1033 m, 1016 w, 991 w-m, 936 m, 917 w, $896 \mathrm{vs}, 839 \mathrm{~m}, 820 \mathrm{w}, 745 \mathrm{~m}, 726 \mathrm{vs}, 693 \mathrm{vs} \mathrm{cm}^{-1} .{ }^{1} \mathrm{H}$ NMR $\left(\mathrm{CD}_{2} \mathrm{Cl}_{2}\right): \delta=7.68(\mathrm{br}, 1 \mathrm{H}, \mathrm{NH}) ; 7.47-7.35(\mathrm{~m}, 5 \mathrm{H}, \mathrm{Ph}) ; 4.83(\mathrm{~s}$, $1 \mathrm{H}, \mathrm{CH}) ; 3.62\left(\mathrm{~m}, 2 \mathrm{H}, \mathrm{CH}_{2}\right) ; 3.34,3.22$ (s, 6H, $\left.\mathrm{NMe}_{2}\right) \mathrm{ppm} .{ }^{13} \mathrm{C}$ $\operatorname{NMR}\left(\mathrm{CD}_{2} \mathrm{Cl}_{2}\right): \delta=170.6(\mathrm{C}=\mathrm{O}) ; 130.7,130.0,129.2(\mathrm{Ph}) ; 127.7$ (ipso-Ph); $76.5(\mathrm{CH}) ; 44.4,43.4\left(\mathrm{NMe}_{2}\right) ; 34.6\left(\mathrm{CH}_{2}\right) \mathrm{ppm} .{ }^{93} \mathrm{Nb}$ $\operatorname{NMR}\left(\mathrm{CD}_{2} \mathrm{Cl}_{2}\right): \delta=8.1\left(\Delta \nu \frac{1}{2}=3 \cdot 10^{2} \mathrm{~Hz}\right) \mathrm{ppm}$.

$\left[\mathrm{MeNH}_{2} \mathrm{CH}_{2} \mathrm{C}(\mathrm{O}) \mathrm{Cl}\right]\left[\mathrm{NbCl}_{6}\right]$, 5b. Yellow solid, yield $144 \mathrm{mg}$ (43\%) from $\mathrm{PCl}_{5} / \mathrm{NbCl}_{5} /$ sarcosine. Anal. calcd for $\mathrm{C}_{3} \mathrm{H}_{7} \mathrm{Cl}_{7}-$ NNbO: C, 8.70; H, 1.70; N, 3.38; Cl, 59.92; Nb, 22.43. Found: C, 8.80; H, 1.59; N, 3.31; Cl, 59.60; Nb, 22.55. IR (solid state): $\nu=$ $3138 \mathrm{~m}-\mathrm{s}\left(\nu_{\mathrm{N}-\mathrm{H}}\right), 2983 \mathrm{w}, 2943 \mathrm{w}, 1766 \mathrm{vs}\left(\nu_{\mathrm{C}=\mathrm{O}}\right), 1546 \mathrm{w}-\mathrm{m}, 1454$ m, 1430 m, 1414 m, 1397 vs, 1341 m, 1160 m, 1129 w, 1036 m, 999 vs, 926 vs, 789 vs, 767 vs cm ${ }^{-1} .{ }^{1} \mathrm{H}$ NMR $\left(\mathrm{CD}_{3} \mathrm{CN}\right): \delta=7.42$ (br, 2H, $\mathrm{NH}_{2}$ ); 4.67 (t, 2H, $\left.{ }^{4} J_{\mathrm{HH}}=5.38 \mathrm{~Hz}, \mathrm{CH}_{2}\right) ; 3.21$ (q, 3H, ${ }^{4} J_{\mathrm{HH}}$ $=5.38 \mathrm{~Hz}, \mathrm{Me})$ ppm. ${ }^{13} \mathrm{C} \mathrm{NMR}\left(\mathrm{CD}_{3} \mathrm{CN}\right): \delta=169.0(\mathrm{C}=\mathrm{O}) ; 58.2$ $\left(\mathrm{CH}_{2}\right) ; 35.9(\mathrm{Me})$ ppm. ${ }^{93} \mathrm{Nb} \mathrm{NMR}\left(\mathrm{CD}_{3} \mathrm{CN}\right): \delta=0.1\left(\Delta \nu \frac{1}{2}=31\right.$ $\mathrm{Hz}) \mathrm{ppm}$. 
Reactions of $\alpha$-amino acids with $\mathrm{PCl}_{5} / \mathrm{WCl}_{6}$ : synthesis of $\left[\mathrm{NH}_{2}\left(\mathrm{CH}_{2}\right)_{3} \mathrm{CHC}(\mathrm{O}) \mathrm{Cl}\right]\left[\mathrm{WCl}_{6}\right], 7 \mathrm{a},\left[\mathrm{Me}_{2} \mathrm{NHCH}\left(\mathrm{CH}_{2} \mathrm{Ph}\right) \mathrm{C}(\mathrm{O}) \mathrm{Cl}\right]$ $\left[\mathrm{WCl}_{6}\right], 7 \mathbf{b}$, and $\left[(\mathrm{R}) \mathrm{NH}_{2} \mathrm{CH}\left(\mathrm{R}^{\prime}\right) \mathrm{C}(\mathrm{O}) \mathrm{Cl}\right]^{+}\left(\mathbf{R}=\mathrm{Me}, \mathbf{R}^{\prime}=\mathbf{H} ; \mathbf{R}=\right.$ $\mathbf{H}, \mathbf{R}^{\prime}=\mathrm{CH}_{2} \mathrm{CH}_{2} \mathrm{SMe}$ )

General procedure. A suspension of $\mathrm{PCl}_{5}(163 \mathrm{mg}, 0.78$ $\mathrm{mmol})$ and $\mathrm{WCl}_{6}(310 \mathrm{mg}, 0.78 \mathrm{mmol})$ in $\mathrm{CD}_{2} \mathrm{Cl}_{2}(4 \mathrm{~mL})$ was stirred at room temperature overnight. Then the appropriate $\alpha$ amino acid $(0.78 \mathrm{mmol})$ was added. The resulting mixture was stirred at room temperature for $3 \mathrm{~h}$. Thus ${ }^{31} \mathrm{P}$ NMR analyses revealed the presence of $\mathrm{POCl}_{3}$ as unique phosphorous species. In addition, ${ }^{1} \mathrm{H}$ and ${ }^{13} \mathrm{C} \mathrm{NMR}$ analyses on $\mathrm{PCl}_{5} / \mathrm{WCl}_{6} / \mathrm{L}-\mathrm{N}, \mathrm{N}$ dimethylphenylalanine and $\mathrm{PCl}_{5} / \mathrm{WCl}_{6} /$ sarcosine solutions pointed out the clean formation of $7 \mathbf{a}$ and $\left[\mathrm{MeNH}_{2} \mathrm{CH}_{2} \mathrm{C}(\mathrm{O}) \mathrm{Cl}\right]^{+}$. These solutions were layered with hexane and stored at $-30{ }^{\circ} \mathrm{C}$ for a few days, thus resulting in the isolation of $7 \mathbf{a}$ and a mixture of $\left[\mathrm{MeNH}_{2} \mathrm{CH}_{2} \mathrm{C}(\mathrm{O}) \mathrm{Cl}\right]^{+}$salts. In the cases of $\mathrm{PCl}_{5} / \mathrm{WCl}_{6} / \mathrm{L}^{-}$ methionine and $\mathrm{PCl}_{5} / \mathrm{WCl}_{6} / \mathrm{L}$-proline, dark solid materials precipitated, which were isolated from the respective yellow solutions and dried in vacuo.

In a different experiment, a $1: 1 \mathrm{PCl}_{5} / \mathrm{WCl}_{6}$ mixture obtained in $\mathrm{CD}_{2} \mathrm{Cl}_{2}(3 \mathrm{~mL})$ was analyzed. $\Lambda_{\mathrm{M}}\left(\mathrm{CD}_{2} \mathrm{Cl}_{2}\right)=0.3 \mathrm{~S} \mathrm{~cm}^{2} \mathrm{~mol}^{-1}$. ${ }^{31} \mathrm{P}$ NMR $\left(\mathrm{CD}_{2} \mathrm{Cl}_{2}\right): \delta=-81.1\left(\mathrm{PCl}_{5}\right) \mathrm{ppm}$. Cl analysis was carried out on the solid residue obtained by removal of the volatiles in vacuo. Anal. calcd for $\mathrm{Cl}_{11} \mathrm{PW}$ : $\mathrm{Cl}, 64.48$. Found: $\mathrm{Cl}, 63.91$. Magnetic measurement: diamagnetic.

$\left[\mathrm{NH}_{2}\left(\mathrm{CH}_{2}\right)_{3} \mathrm{CHC}(\mathrm{O}) \mathrm{Cl}\right]\left[\mathrm{WCl}_{6}\right]$, 7a. Green solid, yield $302 \mathrm{mg}$ (73\%) from $\mathrm{PCl}_{5} / \mathrm{WCl}_{6} / \mathrm{L}$-proline. Anal. calcd for $\mathrm{C}_{5} \mathrm{H}_{9} \mathrm{Cl}_{7} \mathrm{NOW}$ : C, 11.31; H, 1.71; N, 2.64; Cl, 46.72. Found: C, 11.20; H, 1.78; N, 2.50; Cl, 46.33. IR (solid state): $\nu=3133 \mathrm{~m}\left(\nu_{\mathrm{N}-\mathrm{H}}\right), 3073 \mathrm{~m}, 2955$ $\mathrm{w}, 1768 \mathrm{vs}\left(\nu_{\mathrm{C}=\mathrm{O}}\right), 1563 \mathrm{~m}, 1455 \mathrm{w}, 1375 \mathrm{w}-\mathrm{m}, 1343 \mathrm{w}-\mathrm{m}, 1079 \mathrm{w}$, $1043 \mathrm{~m}, 996 \mathrm{vs}, 942 \mathrm{~m}, 906 \mathrm{w}, 864 \mathrm{~m} \mathrm{~cm}^{-1}$. ${ }^{1} \mathrm{H}$ NMR $\left(\mathrm{CD}_{3} \mathrm{CN}\right)$ : $\delta=7.36\left(\mathrm{t}, 2 \mathrm{H},{ }^{3} J_{\mathrm{HH}}=50 \mathrm{~Hz}, \mathrm{NH}_{2}\right) ; 4.80(\mathrm{~m}, 1 \mathrm{H}, \mathrm{CH}) ; 3.45(\mathrm{~m}$, $\left.2 \mathrm{H}, \mathrm{NCH}_{2}\right) ; 2.60,2.36\left(\mathrm{~m}, 2 \mathrm{H}, \mathrm{CH}_{2}\right) ; 2.14-2.06 \mathrm{ppm}(\mathrm{m}, 2 \mathrm{H}$, $\left.\mathrm{CH}_{2}\right)$ ppm. ${ }^{13} \mathrm{C} \mathrm{NMR}\left(\mathrm{CD}_{3} \mathrm{CN}\right): \delta=171.7(\mathrm{C}=\mathrm{O}) ; 68.3(\mathrm{CH}) ; 48.4$ $\left(\mathrm{NCH}_{2}\right) ; 29.1,23.7 \mathrm{ppm}\left(\mathrm{CH}_{2}\right)$ ppm. Magnetic measurement: $\chi_{\mathrm{M}}^{\text {corr }}=3.60 \times 10^{-4} \mathrm{cgsu}, \mu_{\mathrm{eff}}=0.93 \mathrm{BM}$.

$\left[\mathrm{Me}_{2} \mathrm{NHCH}\left(\mathrm{CH}_{2} \mathrm{Ph}\right) \mathrm{C}(\mathrm{O}) \mathrm{Cl}\right]\left[\mathrm{WCl}_{6}\right]$, 7b. Dark yellow - brown solid, yield $285 \mathrm{mg}$ (60\%) from $\mathrm{PCl}_{5} / \mathrm{WCl}_{6} / \mathrm{L}-\mathrm{N}, \mathrm{N}$-dimethylphenylalanine. Anal. calcd for $\mathrm{C}_{11} \mathrm{H}_{15} \mathrm{Cl}_{7} \mathrm{NOW}: \mathrm{C}, 21.69 ; \mathrm{H}, 2.48 ; \mathrm{N}$, 2.30; Cl, 40.73. Found: C, 21.78; H, 2.35; N, 2.20; Cl, 40.32. IR (solid state): $\nu=3122 \mathrm{~m}-\mathrm{br}, 3073 \mathrm{~m}, 2987 \mathrm{w}-\mathrm{m}, 2946 \mathrm{w}, 2789 \mathrm{w}$, 1783 vs $\left(\nu_{\mathrm{C}=\mathrm{O}}\right), 1564 \mathrm{w}, 1455 \mathrm{~m}, 1433 \mathrm{w}-\mathrm{m}, 1400 \mathrm{~m}, 1347 \mathrm{w}, 1260$ w, 1164 w-m, $1041 \mathrm{w}, 1001 \mathrm{~s}, 952 \mathrm{~m}, 930 \mathrm{~m}, 857 \mathrm{~s}, 802 \mathrm{~s}, 774 \mathrm{~s}$ $\mathrm{cm}^{-1} .{ }^{1} \mathrm{H}$ NMR $\left(\mathrm{CD}_{2} \mathrm{Cl}_{2}\right): \delta=7.74(\mathrm{br}, 1 \mathrm{H}, \mathrm{NH}) ; 7.49-7.39(\mathrm{~m}, 5 \mathrm{H}$, $\mathrm{Ph}) ; 4.66$ (br, $1 \mathrm{H}, \mathrm{CH}) ; 3.62$ (m-br, $\left.2 \mathrm{H}, \mathrm{CH}_{2}\right) ; 3.31,3.19$ (s, 6H, $\left.\mathrm{NMe}_{2}\right)$ ppm. ${ }^{13} \mathrm{C} \mathrm{NMR}\left(\mathrm{CD}_{2} \mathrm{Cl}_{2}\right): \delta=170.8(\mathrm{C}=\mathrm{O}) ; 131.3,130.0$, 129.9, 129.2 (Ph); $78.3(\mathrm{CH})$; 50.2, $48.1\left(\mathrm{NMe}_{2}\right)$; $36.7\left(\mathrm{CH}_{2}\right) \mathrm{ppm}$. Magnetic measurement: $\chi_{\mathrm{M}}^{\text {corr }}=4.02 \times 10^{-4} \mathrm{cgsu}, \mu_{\mathrm{eff}}=0.98 \mathrm{BM}$.

$\left[\mathrm{MeNH}_{2} \mathrm{CH}_{2} \mathrm{C}(\mathrm{O}) \mathrm{Cl}\right]^{+}$. Green solid, from $\mathrm{PCl}_{5} / \mathrm{WCl}_{6} /$ sarcosine. IR (solid state): $\nu=3104 \mathrm{~m}-\mathrm{br}\left(\nu_{\mathrm{N}-\mathrm{H}}\right), 2980 \mathrm{w}, 2938 \mathrm{w}, 2796 \mathrm{w}$, 1765 vs $\left(\nu_{\mathrm{C}=\mathrm{O}}\right), 1562 \mathrm{w}-\mathrm{m}, 1455 \mathrm{~m}, 1431 \mathrm{~m}, 1406 \mathrm{~m}, 1345 \mathrm{w}-\mathrm{m}$, 1165 w-m, 1136 w, 1037 w, 1009 s, 991 vs, 951 m, 929 vs, 854 s, 806 vs, $773 \mathrm{vs}, 728 \mathrm{~s} \mathrm{~cm}^{-1}$. ${ }^{1} \mathrm{H}$ NMR $\left(\mathrm{CD}_{3} \mathrm{CN}\right): \delta=7.29(\mathrm{br}, 2 \mathrm{H}$, $\left.\mathrm{NH}_{2}\right) ; 4.58\left(\mathrm{~s}, 2 \mathrm{H}, \mathrm{CH}_{2}\right) ; 3.21(\mathrm{~s}, 3 \mathrm{H}, \mathrm{Me}) \mathrm{ppm} .{ }^{13} \mathrm{C} \mathrm{NMR}$ $\left(\mathrm{CD}_{3} \mathrm{CN}\right): \delta=169.0(\mathrm{C}=\mathrm{O}) ; 63.2\left(\mathrm{CH}_{2}\right) ; 40.4(\mathrm{Me})$ ppm. Magnetic measurement: $\chi_{\mathrm{M}}^{\text {corr }}=1.13 \times 10^{-3} \mathrm{cgsu}$.
$\left[\mathrm{NH}_{3} \mathrm{CH}\left(\mathrm{CH}_{2} \mathrm{CH}_{2} \mathrm{SMe}\right) \mathrm{C}(\mathrm{O}) \mathrm{Cl}\right]^{+}$. Brown solid, from $\mathrm{PCl}_{5} / \mathrm{WCl}_{6} /$ L-methionine. IR (solid state): $\nu=3350 \mathrm{w}-\mathrm{m}\left(\nu_{\mathrm{N}-\mathrm{H}}\right), 3008 \mathrm{w}, 2921$ $\mathrm{w}, 1779 \mathrm{~s}\left(\nu_{\mathrm{C}=\mathrm{O}}\right), 1569 \mathrm{w}, 1480 \mathrm{w}, 1449 \mathrm{w}-\mathrm{m}, 1415 \mathrm{~m}, 1367 \mathrm{w}-\mathrm{m}$, 1309 w, 1263 w, 1176 w, 1144 w, 1094 w, 1025 m, 964 vs, 897 s, 759 s, $733 \mathrm{~m}, 699 \mathrm{w}, 661 \mathrm{w} \mathrm{cm}{ }^{-1}$. Magnetic measurement: $\chi_{\mathrm{M}}^{\text {corr }}=7.08 \times 10^{-4} \mathrm{cgsu}$.

\section{Synthesis of $\alpha$-amino acid ester hydrochlorides}

These compounds were obtained by a slight modification of the literature procedures.

Procedure A (compounds 8a-d·HCl). A $250 \mathrm{~mL}$ flask was charged with the appropriate alcohol $(120 \mathrm{~mL}) / \alpha$-amino acid (ca. $35 \mathrm{mmol}$ ) combination. $\mathrm{SOCl}_{2}(12 \mathrm{~mL}, 170 \mathrm{mmol})$ was slowly added $(3 \mathrm{~h})$ to the suspension under vigorous stirring at room temperature. After $24 \mathrm{~h}$ stirring, volatiles were removed in vacuo at room temperature. The residue was suspended in $\mathrm{Et}_{2} \mathrm{O}$ $(50 \mathrm{~mL})$ for $4 \mathrm{~h}$. The suspension was filtered and the resulting solid was dried in vacuo at $40{ }^{\circ} \mathrm{C}$.

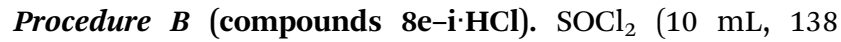
$\mathrm{mmol}$ ) was slowly added (30 minutes) at $0{ }^{\circ} \mathrm{C}$ to the alcohol (80 $\mathrm{mL}$ ) in a $500 \mathrm{~mL}$ Schlenk tube. The solution was then allowed to reach room temperature and the $\alpha$-amino acid $(24 \mathrm{mmol}$ ) was introduced. The mixture was refluxed for $8 \mathrm{~h}$ and a pale yellow solution was obtained. Afterwards, the volatiles were removed in vacuo and the residue was suspended in $\mathrm{Et}_{2} \mathrm{O}(50 \mathrm{~mL})$ for $2 \mathrm{~h}$. The suspension was filtered and the resulting solid was dried in vacuo at $40{ }^{\circ} \mathrm{C}$.

L-Proline methylester hydrochloride, $\mathbf{8 a} \cdot \mathbf{H C l} .^{\mathbf{4 0 a}, \boldsymbol{b}}$ Colourless solid, yield 97\%. IR (liquid film): $\nu=3115 \mathrm{w}\left(\nu_{\mathrm{N}-\mathrm{H}}\right), 3021 \mathrm{w}\left(\nu_{\mathrm{N}-}\right.$ H), $2805 \mathrm{~m}, 1755$ vs $\left(\nu_{\mathrm{C}=\mathrm{O}}\right), 1634 \mathrm{~m}, 1442 \mathrm{~m}, 1391 \mathrm{~m}-\mathrm{s}, 1089 \mathrm{~m}$, $1015 \mathrm{~m} \mathrm{~cm}^{-1} .{ }^{1} \mathrm{H}$ NMR $\left(\mathrm{CDCl}_{3}\right): \delta=10.68,9.04\left(\mathrm{br}, 2 \mathrm{H}, \mathrm{NH}_{2}\right)$; 4.51 (m, 1H, CH); 3.86 (s, 3H, OMe); 3.54 (m, 2H, $\left.\mathrm{NCH}_{2}\right) ; 2.48$, 2.20, $2.10\left(\mathrm{~m}, 4 \mathrm{H}, \mathrm{CH}_{2}\right) \mathrm{ppm} .{ }^{13} \mathrm{C}\left\{{ }^{1} \mathrm{H}\right\} \mathrm{NMR}\left(\mathrm{CDCl}_{3}\right): \delta=169.3$ $(\mathrm{C}=\mathrm{O}) ; 59.2(\mathrm{CH}) ; 53.6 \quad(\mathrm{OMe}) ; 46.0 \quad\left(\mathrm{NCH}_{2}\right) ; 28.7,23.6$ $\left(\mathrm{CH}_{2}\right)$ ppm.

L-Proline ethylester hydrochloride, $\boldsymbol{8 \boldsymbol { b } \cdot \boldsymbol { H C l }}{ }^{\mathbf{4 0 a}}$ Colourless solid, yield 79\%. ${ }^{1} \mathrm{H} \mathrm{NMR}\left(\mathrm{CDCl}_{3}\right): \delta=10.57,8.92\left(\mathrm{br}, 2 \mathrm{H}, \mathrm{NH}_{2}\right) ; 4.42$ $(\mathrm{m}, 1 \mathrm{H}, \mathrm{CH}) ; 4.24\left(\mathrm{q},{ }^{3} J_{\mathrm{HH}}=5.87 \mathrm{~Hz}, 2 \mathrm{H}, \mathrm{OCH}_{2}\right) ; 3.50(\mathrm{~m}, 2 \mathrm{H}$, $\left.\mathrm{NCH}_{2}\right) ; 2.40,2.10\left(\mathrm{~m}, 4 \mathrm{H}, \mathrm{CH}_{2}\right) ; 1.27\left(\mathrm{t},{ }^{3} J_{\mathrm{HH}}=5.87 \mathrm{~Hz}, 3 \mathrm{H}\right.$, $\left.\mathrm{OCH}_{2} \mathrm{CH}_{3}\right)$ ppm. ${ }^{13} \mathrm{C}\left\{{ }^{1} \mathrm{H}\right\} \operatorname{NMR}\left(\mathrm{CDCl}_{3}\right): \delta=168.7(\mathrm{C}=\mathrm{O}) ; 62.9$ $\left(\mathrm{OCH}_{2}\right) ; 59.2(\mathrm{CH}) ; 45.9\left(\mathrm{NCH}_{2}\right) ; 28.7,23.6\left(\mathrm{CH}_{2}\right) ; 14.0$ $\left(\mathrm{OCH}_{2} \mathrm{CH}_{3}\right)$ ppm.

L-Proline isopropylester hydrochloride, $\mathbf{8 c} \cdot \mathbf{H C l}^{\mathbf{4 0 a}}$ Colourless solid, yield 97\%. ${ }^{1} \mathrm{H}$ NMR $\left(\mathrm{CDCl}_{3}\right): \delta=10.70,8.81\left(\mathrm{br}, 2 \mathrm{H}, \mathrm{NH}_{2}\right)$; 5.11 (sept, $\left.{ }^{3} J_{\mathrm{HH}}=6.2 \mathrm{~Hz}, 1 \mathrm{H}, \mathrm{OCH}\right) ; 4.44(\mathrm{~m}, 1 \mathrm{H}, \mathrm{CH}) ; 3.57(\mathrm{~m}$, $\left.2 \mathrm{H}, \mathrm{NCH}_{2}\right) ; 2.43,2.12,2.03\left(\mathrm{~m}, 4 \mathrm{H}, \mathrm{CH}_{2}\right) ; 1.29$ (pseudo-t, ${ }^{3} J_{\mathrm{HH}}=$ $6.2 \mathrm{~Hz}, 6 \mathrm{H}, \mathrm{OCHMe} 2) \mathrm{ppm} .{ }^{13} \mathrm{C}\left\{{ }^{1} \mathrm{H}\right\} \mathrm{NMR}\left(\mathrm{CDCl}_{3}\right): \delta=168.3(\mathrm{C}=$ O); $71.2(\mathrm{OCH}) ; 59.3(\mathrm{CH}) ; 46.1\left(\mathrm{NCH}_{2}\right) ; 29.0,23.6\left(\mathrm{CH}_{2}\right) ; 21.6$ $(\mathrm{OCHMe}) \mathrm{ppm}$.

L-Phenylalanine methylester hydrochloride, $\mathbf{8 d} \cdot \mathbf{H C l} .^{40 b}$ Colourless crystalline solid, yield 83\%. IR (solid state): $\nu=3091 \mathrm{~m}-\mathrm{br}$ $\left(\nu_{\mathrm{N}-\mathrm{H}}\right), 2944 \mathrm{w}$-sh, $2906 \mathrm{w}-\mathrm{sh}, 2838 \mathrm{w}, 2625 \mathrm{w}, 1743 \mathrm{vs}\left(\nu_{\mathrm{C}=\mathrm{O}}\right)$, $1583 \mathrm{w}-\mathrm{m}, 1495 \mathrm{~m}, 1447 \mathrm{w}-\mathrm{m}, 1436 \mathrm{w}-\mathrm{m}, 1400 \mathrm{w}, 1358 \mathrm{w}, 1327 \mathrm{w}$, 1291 w-m, 1238 vs, 1214 vs, 1146 m, 1119 m, 1084 s, 1061 m, $1033 \mathrm{w}, 990 \mathrm{~m}, 934 \mathrm{~m}, 865 \mathrm{w}, 760 \mathrm{n}, 741 \mathrm{vs}, 701 \mathrm{vs} \mathrm{cm}{ }^{-1} \cdot{ }^{1} \mathrm{H}$ $\operatorname{NMR}\left(\mathrm{CDCl}_{3}\right): \delta=8.7\left(\mathrm{br}, 3 \mathrm{H}, \mathrm{NH}_{3}\right) ; 7.31,7.28(\mathrm{~m}, 5 \mathrm{H}, \mathrm{Ph}) ; 4.38$ 
(br, $1 \mathrm{H}, \mathrm{CH}) ; 3.72$ (s, 3H, OMe); 3.42 (m-br, $\left.2 \mathrm{H}, \mathrm{CH}_{2}\right) \mathrm{ppm} .{ }^{13} \mathrm{C}$ $\left\{{ }^{1} \mathrm{H}\right\}$ NMR $\left(\mathrm{CDCl}_{3}\right): \delta=169.2(\mathrm{C}=\mathrm{O}) ; 133.9$ (ipso-Ph); 129.6, 129.0, 127.7 (Ph); $54.4(\mathrm{CH}) ; 53.0(\mathrm{OMe}) ; 36.3\left(\mathrm{CH}_{2}\right) \mathrm{ppm}$.

L-Leucine ethylester hydrochloride, $\mathbf{8 e} \cdot \mathbf{H C l} .^{40 d}$ Colourless solid, yield $80 \% .{ }^{1} \mathrm{H}$ NMR $\left(\mathrm{CDCl}_{3}\right): \delta=8.5\left(\mathrm{br}, 3 \mathrm{H}, \mathrm{NH}_{3}\right) ; 4.26(\mathrm{~m}, 2 \mathrm{H}$, $\left.\mathrm{OCH}_{2}\right) ; 4.07$ (m, 1H, CH); $1.92(\mathrm{~m}, 1 \mathrm{H}, \mathrm{CHMe}$ ); $1.83(\mathrm{~m}, 2 \mathrm{H}$, $\left.\mathrm{CH}_{2}\right) ; 1.31\left(\mathrm{~m}, 6 \mathrm{H}, \mathrm{CHMe} e_{2}\right) ; 1.23\left(\mathrm{t},{ }^{3} \mathrm{~J}_{\mathrm{HH}}=6.85 \mathrm{~Hz}, 3 \mathrm{H}, \mathrm{OCH}_{2^{-}}\right.$ $\left.\mathrm{CH}_{3}\right)$ ppm. ${ }^{13} \mathrm{C}\left\{{ }^{1} \mathrm{H}\right\} \mathrm{NMR}\left(\mathrm{CDCl}_{3}\right): \delta=169.9(\mathrm{C}=\mathrm{O}) ; 62.6\left(\mathrm{OCH}_{2}\right)$; $51.9(\mathrm{CH}) ; 39.5\left(\mathrm{CH}_{2}\right) ; 24.5\left(\mathrm{CHMe}_{2}\right) ; 22.2,22.1\left(\mathrm{CHMe}_{2}\right) ; 14.0$ $\left(\mathrm{OCH}_{2} \mathrm{CH}_{3}\right)$ ppm.

L-Leucine isopropylester hydrochloride, $8 \boldsymbol{f} \cdot \mathbf{H C l}^{\mathbf{4 0 e}}$ Colourless solid, yield $81 \% .{ }^{1} \mathrm{H} \mathrm{NMR}\left(\mathrm{CDCl}_{3}\right): \delta=8.21,6.64\left(\mathrm{br}, 3 \mathrm{H}, \mathrm{NH}_{3}\right)$; $5.11(\mathrm{~m}, 1 \mathrm{H}, \mathrm{OCH}) ; 4.01(\mathrm{~m}, 1 \mathrm{H}, \mathrm{CH}) ; 1.89(\mathrm{~m}, 1 \mathrm{H}, \mathrm{CHMe}) ; 1.81$ $\left(\mathrm{m}, 2 \mathrm{H}, \mathrm{CH}_{2}\right) ; 1.28\left(\mathrm{~m}, 6 \mathrm{H}, \mathrm{CHMe} e_{2}\right) ; 0.98\left(\mathrm{~m}, 6 \mathrm{H}, \mathrm{OCHMe}_{2}\right) \mathrm{ppm}$. ${ }^{13} \mathrm{C}\left\{{ }^{1} \mathrm{H}\right\} \mathrm{NMR}\left(\mathrm{CDCl}_{3}\right): \delta=169.3(\mathrm{C}=\mathrm{O}) ; 70.8(\mathrm{OCH}) ; 52.0(\mathrm{CH})$; $39.5\left(\mathrm{CH}_{2}\right) ; 24.8\left(\mathrm{CHMe}_{2}\right) ; 22.2\left(\mathrm{CHMe}_{2}\right) ; 21.6\left(\mathrm{OCHMe}_{2}\right) \mathrm{ppm}$.

Glycine isopropylester hydrochloride, $\mathbf{8 g} \cdot \mathbf{H C l}^{\mathbf{4 0} f}$ Colourless solid, $97 \%$ yield. ${ }^{1} \mathrm{H}$ NMR $\left(\mathrm{CDCl}_{3}\right): \delta=8.50\left(\mathrm{br}, 3 \mathrm{H}, \mathrm{NH}_{3}\right) ; 5.10$ (sept, $\left.{ }^{3} J_{\mathrm{HH}}=6.1 \mathrm{~Hz}, 1 \mathrm{H}, \mathrm{OCH}\right) ; 3.96\left(\mathrm{q},{ }^{3} J_{\mathrm{HH}}=4.2 \mathrm{~Hz}, 2 \mathrm{H}, \mathrm{CH}_{2}\right.$ ); $\left.1.26\left(\mathrm{~d},{ }^{3} J_{\mathrm{HH}}=6.1 \mathrm{~Hz}, 6 \mathrm{H}, \mathrm{CHMe}\right)_{2}\right) \mathrm{ppm}$.

L-Serine isopropylester hydrochloride, $\mathbf{8 h} \cdot \mathbf{H C l}{ }^{\mathbf{4 0 g}}$ Colourless solid, 98\% yield. ${ }^{1} \mathrm{H}$ NMR (DMSO-d ${ }_{6}$ ): $\delta=8.51\left(\mathrm{br}, 3 \mathrm{H}, \mathrm{NH}_{3}\right.$ ); 5.71-5.52 (m, 1H, OH); 5.05-4.94 (m, 1H, CHMe $)$; 4.04-3.98 (m, $\left.1 \mathrm{H}, \mathrm{CHH}^{\prime}\right) ; 3.83-3.78\left(\mathrm{~s}, 2 \mathrm{H}, \mathrm{CH} H^{\prime}+\mathrm{CHN}\right) ; 1.26-1.21(\mathrm{~m}, 6 \mathrm{H}$, $\mathrm{CHMe}_{2}$ ) ppm. ${ }^{13} \mathrm{C}\left\{{ }^{1} \mathrm{H}\right\}$ NMR (DMSO-d ${ }_{6}$ ): $\delta=167.6$ (CO); 69.6 $\left(\mathrm{CHMe}_{2}\right) ; 59.5\left(\mathrm{CH}_{2}\right) ; 54.4(\mathrm{CHN}) ; 21.5$ and $21.4\left(\mathrm{CHMe}_{2}\right) \mathrm{ppm}$.

L-Tyrosine isopropylester hydrochloride, $\mathbf{8 i} \cdot \mathbf{H C l} .^{\mathbf{4 0 h}}$ Colourless solid, 71\% yield. ${ }^{1} \mathrm{H}$ NMR (DMSO-d $\left.{ }_{6}\right): \delta=9.49(\mathrm{~s}, 1 \mathrm{H}, \mathrm{OH}) ; 8.49$ (br, $\left.3 \mathrm{H}, \mathrm{NH}_{3}\right) ; 7.01\left(\mathrm{~d},{ }^{3} J_{\mathrm{HH}}=8.2 \mathrm{~Hz}, 2 \mathrm{H}, \mathrm{Ar}\right) ; 6.71\left(\mathrm{~d},{ }^{3} J_{\mathrm{HH}}=\right.$ $8.2 \mathrm{~Hz}, 2 \mathrm{H}, \mathrm{Ar}) ; 4.88$ (sept, $\left.{ }^{3} \mathrm{~J}_{\mathrm{HH}}=5.9 \mathrm{~Hz}, 1 \mathrm{H}, \mathrm{OCH}\right) ; 4.07\left(\mathrm{t},{ }^{3} J_{\mathrm{HH}}\right.$ $=6.6 \mathrm{~Hz}, 1 \mathrm{H}, \mathrm{NCH}) ; 3.17-2.83\left(\mathrm{~m}, 2 \mathrm{H}, \mathrm{CH}_{2}\right) ; 1.16\left(\mathrm{~d},{ }^{3} J_{\mathrm{HH}}=\right.$ $6.2 \mathrm{~Hz}, 3 \mathrm{H})$ and $1.06\left(\mathrm{~d},{ }^{3} J_{\mathrm{HH}}=6.2 \mathrm{~Hz}, 3 \mathrm{H}, \mathrm{CHMe} e_{2}\right) \mathrm{ppm}$.

Synthesis of $\boldsymbol{\alpha}$-amino acid esters. Three different procedures were adopted. Compounds $\mathbf{8 a}-\mathbf{g}$ were prepared by treating the appropriate $\alpha$-amino acid ester hydrochloride with $\mathrm{NH}_{3(\mathrm{aq})}$ as described in detail for $\mathbf{8 a}$. Compounds $\mathbf{8 h}-\mathbf{j}$ were prepared by treating the appropriate $\alpha$-amino acid ester hydrochloride with $\mathrm{NaOH}_{(\mathrm{aq})}$ as described in detail for $\mathbf{8 h}$. Compounds 8k-1 were obtained directly from the appropriate alcohol/ $\alpha$-amino acid (ca. $50 \mathrm{mmol}$ ) combination, followed by treatment with $\mathrm{NH}_{3(\mathrm{aq})}$; attempts to isolate $(\mathbf{8 k - 1}) \cdot \mathbf{H C l}$ led to mixtures of products.

L-Proline methylester, 8a. ${ }^{40 a, c}$ Compound 8a· HCl (10.2 g, 60.4 mmol) was dissolved into $\mathrm{CH}_{2} \mathrm{Cl}_{2}(100 \mathrm{~mL})$ and the solution was treated with a $28 \% \mathrm{w} / \mathrm{w} \mathrm{NH}_{3}$ aqueous solution until neutrality. The mixture was left stirring at room temperature for $24 \mathrm{~h}$. The phases were separated and the aqueous layer was extracted with $\mathrm{CH}_{2} \mathrm{Cl}_{2}(2 \times 50 \mathrm{~mL})$. The organic phase was filtered through an alumina pad and solvent was removed by distillation at $40{ }^{\circ} \mathrm{C}$ and $p=700$ mbar. The product was obtained as a pale orange liquid, which was stored under argon. Yield $4.71 \mathrm{~g}(60 \%) .{ }^{1} \mathrm{H}$ NMR $\left(\mathrm{CDCl}_{3}\right): \delta=3.54\left(\mathrm{~s}, 3 \mathrm{H}, \mathrm{CH}_{3}\right) ; 2.92(\mathrm{~m}, 1 \mathrm{H}, \mathrm{CH}) ; 2.48(\mathrm{~m}$, $\left.2 \mathrm{H}, \mathrm{CH}_{2} \mathrm{~N}\right) ; 1.99,1.64\left(\mathrm{~m}, 4 \mathrm{H}, \mathrm{CH}_{2}\right) \mathrm{ppm}$.

L-Proline ethylester, 8b. ${ }^{40 a}$ Pale yellow liquid, yield 65\%. IR (liquid film): $\nu=1730 \mathrm{vs}\left(\nu_{\mathrm{C}=\mathrm{O}}\right) \mathrm{cm}^{-1} \cdot{ }^{1} \mathrm{H} \mathrm{NMR}\left(\mathrm{CDCl}_{3}\right): \delta=4.12$ $\left(\mathrm{q},{ }^{3} \mathrm{~J}_{\mathrm{HH}}=6.85 \mathrm{~Hz}, 2 \mathrm{H}, \mathrm{OCH}_{2}\right) ; 3.73(\mathrm{~m}, 1 \mathrm{H}, \mathrm{CH}) ; 3.03,2.90(\mathrm{~m}$, $\left.2 \mathrm{H}, \mathrm{NCH}_{2}\right) ; 2.07,1.81,1.73\left(\mathrm{~m}, 4 \mathrm{H}, \mathrm{CH}_{2}\right) ; 1.22\left(\mathrm{t},{ }^{3} J_{\mathrm{HH}}=6.85 \mathrm{~Hz}\right.$, $\left.3 \mathrm{H}, \mathrm{OCH}_{2} \mathrm{CH}_{3}\right)$ ppm. ${ }^{13} \mathrm{C}\left\{{ }^{1} \mathrm{H}\right\} \mathrm{NMR}\left(\mathrm{CDCl}_{3}\right): \delta=173.9(\mathrm{C}=\mathrm{O})$;
$61.0\left(\mathrm{OCH}_{2}\right) ; 59.7(\mathrm{CH}) ; 46.9\left(\mathrm{NCH}_{2}\right) ; 30.2,25.4\left(\mathrm{CH}_{2}\right) ; 14.2$ $\left(\mathrm{OCH}_{2} \mathrm{CH}_{3}\right) \mathrm{ppm}$.

L-Proline isopropylester, $8 \mathrm{cc}^{40 i}$ Pale orange liquid, yield $60 \%$. ${ }^{1} \mathrm{H} \mathrm{NMR}\left(\mathrm{CDCl}_{3}\right): \delta=5.03\left(\mathrm{sept},{ }^{3} J_{\mathrm{HH}}=6.3 \mathrm{~Hz}, 1 \mathrm{H}, \mathrm{OCH}\right) ; 3.71$ $\left(\mathrm{dd},{ }^{3} J_{\mathrm{HH}}=8.3,5.6 \mathrm{~Hz}, 1 \mathrm{H}, \mathrm{CH}\right) ; 3.12-3.04\left(\mathrm{~m}, 1 \mathrm{H}, \mathrm{NCHH}^{\prime}\right)$; 2.94-2.85 (m, 1H, NCH $\left.H^{\prime}\right) ; 2.28\left(\mathrm{br}, 2 \mathrm{H}, \mathrm{NH}_{2}\right) ; 2.18-2.06(\mathrm{~m}, 1 \mathrm{H})$ and $1.86-1.67\left(\mathrm{~m}, 3 \mathrm{H}, \mathrm{CH}_{2} \mathrm{CH}_{2}\right) ; 1.25\left(\mathrm{~d},{ }^{3} J_{\mathrm{HH}}=3.5 \mathrm{~Hz}, 3 \mathrm{H}\right.$, $\mathrm{CHMeMe}$ ); 1.23 (d, $\left.{ }^{3} \mathrm{~J}_{\mathrm{HH}}=3.6 \mathrm{~Hz}, 3 \mathrm{H}, \mathrm{CHMeMe} e^{\prime}\right) \mathrm{ppm} .{ }^{13} \mathrm{C}\left\{{ }^{1} \mathrm{H}\right\}$ NMR $\left(\mathrm{CDCl}_{3}\right): \delta=174.6(\mathrm{C}=\mathrm{O}) ; 68.0(\mathrm{OCH}) ; 59.6(\mathrm{CH}) ; 46.8$ $\left(\mathrm{NCH}_{2}\right) ; 30.1,25.2\left(\mathrm{CH}_{2}\right) ; 21.5\left(\mathrm{OCHMe}_{2}\right) \mathrm{ppm}$.

L-Phenylalanine methylester, 8d. ${ }^{40 c}$ Pale orange liquid, yield $63 \%$. IR (liquid film): $\nu=3381 \mathrm{w}\left(\nu_{\mathrm{N}-\mathrm{H}}\right), 3062 \mathrm{w}, 3028 \mathrm{w}, 2951 \mathrm{w}$, 1732 vs $\left(\nu_{\mathrm{C}=\mathrm{O}}\right), 1603 \mathrm{w}-\mathrm{m}, 1496 \mathrm{~m}, 1454 \mathrm{~m}, 1436 \mathrm{~m}, 1266 \mathrm{~m}$, $1195 \mathrm{~s}, 1172 \mathrm{~s}, 1111 \mathrm{~m}, 1076 \mathrm{~m}, 1009$ m, $826 \mathrm{~m}, 812 \mathrm{~m}, 744 \mathrm{~m}-\mathrm{s}$, $699 \mathrm{vs} \mathrm{cm}^{-1} .{ }^{1} \mathrm{H} \mathrm{NMR}\left(\mathrm{CDCl}_{3}\right): \delta=7.24-7.12(5 \mathrm{H}, \mathrm{Ph}) ; 3.66(\mathrm{~m}$, $1 \mathrm{H}, \mathrm{CH}) ; 3.63$ (s, 3H, OMe); 3.01, $2.80\left(\mathrm{~m}, 2 \mathrm{H}, \mathrm{CH}_{2}\right) \mathrm{ppm} .{ }^{13} \mathrm{C}$ $\left\{{ }^{1} \mathrm{H}\right\} \operatorname{NMR}\left(\mathrm{CDCl}_{3}\right): \delta=175.3(\mathrm{C}=\mathrm{O}) ; 137.3$ (ipso-Ph); 129.3, 128.5, 126.7 (Ph); 55.8 (OMe); $51.8(\mathrm{CH}) ; 41.0\left(\mathrm{CH}_{2}\right) \mathrm{ppm}$.

L-Leucine ethylester, 8e. ${ }^{40 d}$ Pale yellow liquid, yield $74 \% .{ }^{1} \mathrm{H}$ NMR $\left(\mathrm{CDCl}_{3}\right): \delta=4.16\left(\mathrm{~m}, 2 \mathrm{H}, \mathrm{OCH}_{2}\right) ; 3.44(\mathrm{~m}, 1 \mathrm{H}, \mathrm{CH}) ; 1.77$ (m, 1H, CHMe $\mathrm{M}_{2}$; 1.65 (s, 2H, NH $\left.\mathrm{NH}_{2}\right) ; .55,1.43\left(\mathrm{~m}, 2 \mathrm{H}, \mathrm{CH}_{2}\right) ; 1.27$ $\left(\mathrm{t},{ }^{3} J_{\mathrm{HH}}=6.85 \mathrm{~Hz}, 3 \mathrm{H}, \mathrm{OCH}_{2} \mathrm{CH}_{3}\right) ; 0.93\left(\mathrm{~m}, 6 \mathrm{H}, \mathrm{CHMe} e_{2}\right) \mathrm{ppm}$. ${ }^{13} \mathrm{C}\left\{{ }^{1} \mathrm{H}\right\} \operatorname{NMR}\left(\mathrm{CDCl}_{3}\right): \delta=176.5(\mathrm{C}=\mathrm{O}) ; 60.7\left(\mathrm{OCH}_{2}\right) ; 52.9(\mathrm{CH})$; $44.0 \quad\left(\mathrm{CH}_{2}\right) ; \quad 24.7 \quad\left(\mathrm{CHMe}_{2}\right) ; \quad 22.9, \quad 21.8 \quad\left(\mathrm{CHMe}_{2}\right) ; \quad 14.2$ $\left(\mathrm{OCH}_{2} \mathrm{CH}_{3}\right)$ ppm.

L-Leucine isopropylester, 8 8f. $^{40 e}$ Pale yellow liquid, yield $55 \%$. ${ }^{1} \mathrm{H} \mathrm{NMR}\left(\mathrm{CDCl}_{3}\right): \delta=5.05$ (sept, $\left.1 \mathrm{H}, \mathrm{OCH}\right) ; 3.49(\mathrm{~m}, 1 \mathrm{H}, \mathrm{CH})$; $2.90\left(\mathrm{~s}, 2 \mathrm{H}, \mathrm{NH}_{2}\right) ; 1.80\left(\mathrm{~m}, 1 \mathrm{H}, \mathrm{CHMe}\right.$ ); 1.57, $1.50\left(\mathrm{~m}, 2 \mathrm{H}, \mathrm{CH}_{2}\right)$; $1.26\left(\mathrm{~m}, 6 \mathrm{H}, \mathrm{OCHMe}_{2}\right) ; 0.94\left(\mathrm{~m}, 6 \mathrm{H}, \mathrm{CHMe} e_{2}\right) \mathrm{ppm} .{ }^{13} \mathrm{C}\left\{{ }^{1} \mathrm{H}\right\} \mathrm{NMR}$ $\left(\mathrm{CDCl}_{3}\right): \delta=175.1(\mathrm{C}=\mathrm{O}) ; 68.5(\mathrm{OCH}) ; 52.8(\mathrm{CH}) ; 43.5\left(\mathrm{CH}_{2}\right)$; $24.7\left(\mathrm{CHMe}_{2}\right) ; 22.9,21.9\left(\mathrm{CHMe} e_{2}\right) ; 21.7\left(\mathrm{OCHMe}_{2}\right) \mathrm{ppm}$.

Glycine isopropylester, 8g. ${ }^{40 f}$ Pale yellow viscous liquid, yield $60 \% .{ }^{1} \mathrm{H} \mathrm{NMR}\left(\mathrm{CDCl}_{3}\right): \delta=5.05$ (sept, $\left.{ }^{3} \mathrm{~J}_{\mathrm{HH}}=6.3 \mathrm{~Hz}, 1 \mathrm{H}, \mathrm{OCH}\right)$; $3.40\left(\mathrm{~s}, 2 \mathrm{H}, \mathrm{CH}_{2}\right) ; 1.89\left(\mathrm{br}, 2 \mathrm{H}, \mathrm{NH}_{2}\right) ; 1.24\left(\mathrm{~d},{ }^{3} J_{\mathrm{HH}}=6.2 \mathrm{~Hz}, 6 \mathrm{H}\right.$, $\left.\mathrm{CHMe}_{2}\right) \mathrm{ppm}$.

L-Serine isopropylester, $8 \mathbf{~ h}^{40 f}$ Compound $8 \mathbf{h} \cdot \mathbf{H C l}(1.61 \mathrm{~g}, 8.75$ mmol) was dissolved in $\mathrm{NaOH} 1.0 \mathrm{M}(8.75 \mathrm{~mL}, 8.75 \mathrm{mmol})$ in a $25 \mathrm{~mL}$ round bottom flask. The solution was stirred at room temperature for 10 minutes then extracted with $\mathrm{CH}_{2} \mathrm{Cl}_{2}(3 \times 20$ $\mathrm{mL})$. The organic phase was dried with $\mathrm{Na}_{2} \mathrm{SO}_{4}$, filtered and the solvent was removed by distillation at $40^{\circ} \mathrm{C}$ and $p=700$ mbar. The product was obtained as a colourless viscous liquid, $1.11 \mathrm{~g}$, yield $87 \%$. IR(liquid film): $\nu=3500-3100 \mathrm{br}, 3362 \mathrm{w}, 3308 \mathrm{w}$, $2981 \mathrm{w}, 2938 \mathrm{w}, 2879 \mathrm{w}, 1728 \mathrm{~s}\left(\nu_{\mathrm{C}=\mathrm{O}}\right), 1595 \mathrm{w}, 1468 \mathrm{w}, 1455 \mathrm{w}$, 1384 w-sh, 1375 m, 1326 w, 1209 m, 1179 m, 1145 m, 1105 s, $1039 \mathrm{~m}, 933 \mathrm{~m}, 903 \mathrm{w}, 849 \mathrm{w}, 822 \mathrm{~m} \mathrm{~cm}^{-1} .{ }^{1} \mathrm{H} \mathrm{NMR}\left(\mathrm{CDCl}_{3}\right): \delta=$ 5.07 (sept, $\left.{ }^{3} J_{\mathrm{HH}}=6.2 \mathrm{~Hz}, 1 \mathrm{H}, \mathrm{OCH}\right) ; 3.85\left(\mathrm{dd},{ }^{2} J_{\mathrm{HH}}=10.2 \mathrm{~Hz}\right.$, $\left.{ }^{3} J_{\mathrm{HH}}=2.5 \mathrm{~Hz}, 1 \mathrm{H}, \mathrm{C} H \mathrm{H}^{\prime}\right) ; 3.71\left(\mathrm{dd},{ }^{2} J_{\mathrm{HH}}=10.7 \mathrm{~Hz},{ }^{3} J_{\mathrm{HH}}=\right.$ $\left.5.8 \mathrm{~Hz}, 1 \mathrm{H}, \mathrm{CH} H^{\prime}\right) ; 3.66-3.60(\mathrm{~m}, 1 \mathrm{H}, \mathrm{CHN}) ; 2.59$ (br, 3H, $\mathrm{NH}_{2}+$ $\mathrm{OH})$; $1.29-1.25(\mathrm{~m}, 6 \mathrm{H}, \mathrm{CHMe} 2) \mathrm{ppm} .{ }^{13} \mathrm{C}\left\{{ }^{1} \mathrm{H}\right\} \mathrm{NMR}\left(\mathrm{CDCl}_{3}\right): \delta=$ 173.3 (CO); $68.8(\mathrm{OCH}) ; 63.9\left(\mathrm{CH}_{2}\right) ; 56.1(\mathrm{CHN}) ; 21.7\left(\mathrm{Me}_{2}\right)$ ppm. ${ }^{1} \mathrm{H}$ NMR $\left(\mathrm{CD}_{3} \mathrm{CN}\right): \delta=4.97\left(\mathrm{sept},{ }^{3} J_{\mathrm{HH}}=6.3 \mathrm{~Hz}, 1 \mathrm{H}, \mathrm{OCH}\right) ; 3.62-$ $3.58\left(\mathrm{~m}, 2 \mathrm{H}, \mathrm{CH}_{2}\right) ; 3.38\left(\mathrm{t},{ }^{3} J_{\mathrm{HH}}=4.8 \mathrm{~Hz}, 1 \mathrm{H}, \mathrm{CHN}\right) ; 2.19(\mathrm{br}, 3 \mathrm{H}$, $\left.\mathrm{NH}_{2}+\mathrm{OH}\right) ; 1.23-1.20\left(\mathrm{~m}, 6 \mathrm{H}, \mathrm{Me}_{2}\right)$ ppm. ${ }^{13} \mathrm{C}\left\{{ }^{1} \mathrm{H}\right\} \mathrm{NMR}\left(\mathrm{CD}_{3} \mathrm{CN}\right)$ : $\delta=174.6(\mathrm{CO}) ; 68.9(\mathrm{OCH}) ; 65.1\left(\mathrm{CH}_{2}\right) ; 57.3(\mathrm{CHN}) ; 22.0$ and $21.9\left(\mathrm{Me}_{2}\right)$ ppm. The compound was dissolved in $\mathrm{CDCl}_{3}$ and stored in a graduated Schlenk tube under nitrogen. The 
concentration of the solution was determined by ${ }^{1} \mathrm{H}$ NMR, using $\mathrm{CH}_{2} \mathrm{Br}_{2}$ as internal standard.

L-Tyrosine isopropylester, $\mathbf{8 i}^{40 j}$ Colourless solid, yield $83 \%$. ${ }^{1} \mathrm{H}$ NMR $\left(\mathrm{CDCl}_{3}\right): \delta=7.02\left(\mathrm{~d},{ }^{3} \mathrm{~J}_{\mathrm{HH}}=8.3 \mathrm{~Hz}, 2 \mathrm{H}, \mathrm{Ph}\right) ; 6.68(\mathrm{~d}$, $\left.{ }^{3} J_{\mathrm{HH}}=8.3 \mathrm{~Hz}, 2 \mathrm{H}, \mathrm{Ph}\right) ; 5.05\left(\mathrm{sept},{ }^{3} J_{\mathrm{HH}}=6.5 \mathrm{~Hz}, 1 \mathrm{H}, \mathrm{OCH}\right)$; 3.73-3.63 (m, 1H, NCH); $3.23\left(\mathrm{br}, 3 \mathrm{H}, \mathrm{NH}_{2}+\mathrm{OH}\right) ; 3.04\left(\mathrm{dd},{ }^{2} J_{\mathrm{HH}}\right.$ $\left.=13.8 \mathrm{~Hz},{ }^{3} J_{\mathrm{HH}}=5.0 \mathrm{~Hz}, 1 \mathrm{H}, \mathrm{CHH}\right) ; 2.81\left(\mathrm{dd},{ }^{2} J_{\mathrm{HH}}=13.7 \mathrm{~Hz}\right.$, $\left.{ }^{3} J_{\mathrm{HH}}=7.7 \mathrm{~Hz}, 1 \mathrm{H}, \mathrm{CHH} \mathrm{H}^{\prime}\right) ; 1.29-1.22(\mathrm{~m}, 6 \mathrm{H}, \mathrm{CHMe}) \mathrm{ppm}$.

L-Alanine ethylester, $8 \mathbf{j}^{40 k}$ Prepared from commercial Lalanine ethylester hydrochloride (Fluka). Pale yellow viscous liquid, yield $60 \% .{ }^{1} \mathrm{H} \mathrm{NMR}\left(\mathrm{CDCl}_{3}\right): \delta=4.01\left(\mathrm{q},{ }^{3} \mathrm{~J}_{\mathrm{HH}}=6.6 \mathrm{~Hz}\right.$, $\left.2 \mathrm{H}, \mathrm{OCH}_{2}\right) ; 3.37\left(\mathrm{q},{ }^{3} J_{\mathrm{HH}}=6.6 \mathrm{~Hz}, 1 \mathrm{H}, \mathrm{NCH}\right) ; 1.54\left(\mathrm{br}, 2 \mathrm{H}, \mathrm{NH}_{2}\right)$; $1.17\left(\mathrm{~d},{ }^{3} J_{\mathrm{HH}}=6.9 \mathrm{~Hz}, 3 \mathrm{H}, \mathrm{CH}_{3} \mathrm{CH}\right) ; 1.13\left(\mathrm{t},{ }^{3} J_{\mathrm{HH}}=7.1 \mathrm{~Hz}, 3 \mathrm{H}\right.$, $\left.\mathrm{CH}_{3} \mathrm{CH}_{2}\right) \mathrm{ppm}$.

L-Leucine methylester, $8 \mathbf{k}^{40 l}$ Pale yellow liquid, yield $42 \%$. IR (liquid film): $\nu=3380 \mathrm{w}-\mathrm{m}\left(\nu_{\mathrm{N}-\mathrm{H}}\right), 2956 \mathrm{~m}, 2932 \mathrm{w}, 2869 \mathrm{w}, 2851$ $\mathrm{w}, 1740 \mathrm{vs}\left(\nu_{\mathrm{C}=\mathrm{O}}\right), 1610 \mathrm{w}, 1468 \mathrm{~m}, 1436 \mathrm{~m}, 1384 \mathrm{w}, 1368 \mathrm{w}, 1316$ w, $1270 \mathrm{~m}, 1198 \mathrm{~s}, 1145 \mathrm{~m}, 1010 \mathrm{~m}, 971 \mathrm{w}, 921 \mathrm{w}, 869 \mathrm{w}, 837 \mathrm{w}$, $822 \mathrm{w} \mathrm{cm}^{-1} .{ }^{1} \mathrm{H}$ NMR $\left(\mathrm{CDCl}_{3}\right): \delta=3.64(\mathrm{~s}, 3 \mathrm{H}, \mathrm{OMe}) ; 3.41(\mathrm{~m}$, $1 \mathrm{H}, \mathrm{CH}) ; 1.70\left(\mathrm{~m}, 1 \mathrm{H}, \mathrm{CHMe} \mathrm{Me}_{2}\right) ; 1.65\left(\mathrm{~s}, 2 \mathrm{H}, \mathrm{NH}_{2}\right) ; 1.4(\mathrm{~m}-\mathrm{br}, 2 \mathrm{H}$, $\left.\mathrm{CH}_{2}\right) ; 0.86\left(\mathrm{~m}, 6 \mathrm{H}, \mathrm{CHMe} e_{2}\right)$ ppm. ${ }^{13} \mathrm{C}\left\{{ }^{1} \mathrm{H}\right\}$ NMR $\left(\mathrm{CDCl}_{3}\right): \delta=$ $177.1(\mathrm{C}=\mathrm{O}) ; 53.0(\mathrm{OMe}) ; 52.0(\mathrm{CH}) ; 44.2\left(\mathrm{CH}_{2}\right) ; 24.8\left(\mathrm{CHMe}_{2}\right)$; 23.2, $22.0\left(\mathrm{CHMe}_{2}\right) \mathrm{ppm}$.

L-Phenylalanine isopropylester, $8 \mathbf{8 1}^{40 \mathrm{~m}}$ Colourless solid, yield 36\%. ${ }^{1} \mathrm{H}$ NMR $\left(\mathrm{CDCl}_{3}\right): \delta:$ M7.32-7.22 (5H, Ph); 5.03 (sept, $1 \mathrm{H}$, $\mathrm{OCH}) ; 3.71(\mathrm{~m}, 1 \mathrm{H}, \mathrm{CH}) ; 3.08,2.90\left(\mathrm{~m}, 2 \mathrm{H}, \mathrm{CH}_{2}\right) ; 2.10(\mathrm{~s}, 2 \mathrm{H}$, $\left.\mathrm{NH}_{2}\right) ; 1.24,1.20\left(\mathrm{~m}, 6 \mathrm{H}, \mathrm{OCHMe}_{2}\right) \mathrm{ppm} .{ }^{13} \mathrm{C}\left\{{ }^{1} \mathrm{H}\right\} \mathrm{NMR}\left(\mathrm{CDCl}_{3}\right): \mathrm{R}$ (174.2 (C=O); 137.2 (ipso-Ph); 129.4, 128.5, $126.8(\mathrm{Ph}) ; 68.6$ $(\mathrm{OCH}) ; 55.8(\mathrm{CH}) ; 40.9\left(\mathrm{CH}_{2}\right) ; 21.7(\mathrm{OCHMe}) \mathrm{ppm}$.

\section{Reactions of $\mathrm{NbF}_{5}$ with $\alpha$-amino acid esters}

Synthesis of $\left[\mathrm{NbF}_{4}\left(\mathrm{Me}_{2} \mathrm{CHCH}_{2} \mathrm{CHNH}_{2} \mathrm{CO}_{2} \mathrm{Me}\right)_{2}\right]\left[\mathrm{NbF}_{6}\right]$, 9. A suspension of $\mathrm{NbF}_{5}(167 \mathrm{mg}, 1.15 \mathrm{mmol})$ in $\mathrm{CH}_{2} \mathrm{Cl}_{2}(15 \mathrm{~mL})$ was treated with $8 \mathbf{k}(167 \mathrm{mg}, 1.15 \mathrm{mmol})$. After $24 \mathrm{~h}$ stirring at room temperature, a colourless solution was obtained. By addition of hexane $(10 \mathrm{~mL}), 9$ was obtained as a colourless solid, which was recovered by filtration and dried in vacuo at room temperature. Yield $185 \mathrm{mg}$ (48\%). Anal. calcd for $\mathrm{C}_{14} \mathrm{H}_{30} \mathrm{~F}_{10} \mathrm{~N}_{2} \mathrm{Nb}_{2} \mathrm{O}_{4}$ : C, 25.24; $\mathrm{H}, 4.54 ; \mathrm{N}, 4.20 ; \mathrm{Nb}, 27.89$. Found: C, $25.01 ; \mathrm{H}, 4.1 ; \mathrm{N}, 4.01 ; \mathrm{Nb}$, 25.71. IR (solid state): $\nu=3232 \mathrm{w}\left(\nu_{\mathrm{N}-\mathrm{H}}\right), 3064 \mathrm{~m}, 2966 \mathrm{~m}, 2877$ $\mathrm{m}, 1648 \mathrm{vs}\left(\nu_{\mathrm{C}=\mathrm{O}}\right), 1499 \mathrm{~m}, 1456 \mathrm{~m}, 1374 \mathrm{w}, 1328 \mathrm{w}, 1289 \mathrm{w}, 1262$ $\mathrm{w}, 1170 \mathrm{w}, 1129 \mathrm{w}, 1067 \mathrm{w}, 834 \mathrm{br}-\mathrm{s} \mathrm{cm}^{-1}$. ${ }^{1} \mathrm{H} \mathrm{NMR}\left(\mathrm{CDCl}_{3}\right): \delta=$ 8.6, $7.0\left(\mathrm{br}, 2 \mathrm{H}, \mathrm{NH}_{2}\right) ; 4.66$ (s, 3H, OMe); $4.19(\mathrm{~m}, 1 \mathrm{H}, \mathrm{CH}) ; 2.02-$ $\left.1.52\left(\mathrm{~m}, 3 \mathrm{H}, \mathrm{CHMe} \mathrm{Me}_{2}+\mathrm{CH}_{2}\right) ; 1.03(\mathrm{~m}, 6 \mathrm{H}, \mathrm{CHMe})_{2}\right) \mathrm{ppm} .{ }^{19} \mathrm{~F} \mathrm{NMR}$ $\left(\mathrm{CDCl}_{3}\right): \delta=140\left(\Delta \nu_{1 / 2}=2.5 \times 10^{3} \mathrm{~Hz}, \mathrm{NbF}_{4}{ }^{+}\right) ; 103\left(\right.$ decet, ${ }^{1} J_{\mathrm{NbF}}$ $=345 \mathrm{~Hz}, \mathrm{NbF}_{6}{ }^{-}$) ppm. ${ }^{93} \mathrm{Nb} \mathrm{NMR}\left(\mathrm{CDCl}_{3}\right): \delta=-1553$ (septet, ${ }^{1} J_{\mathrm{NbF}}=366 \mathrm{~Hz}, \mathrm{NbF}_{6}{ }^{-}$) ppm.

Synthesis of $\left[\mathrm{NbF}_{3}\left(\mathrm{HNCH}_{2} \mathrm{CH}_{2} \mathrm{CH}_{2} \mathrm{CHCO}_{2}\right)\right]\left[\mathrm{NbF}_{6}\right]$, 10. Compound 10 was prepared by a procedure analogous to that described for the synthesis of $\mathbf{9}$, from $\mathrm{NbF}_{5}(222 \mathrm{mg}, 1.18 \mathrm{mmol})$ and $\mathbf{8 b}$ $(85 \mathrm{mg}, 0.59 \mathrm{mmol})$. Yield $167 \mathrm{mg}(60 \%)$. Anal. calcd for $\mathrm{C}_{5} \mathrm{H}_{8^{-}}$ $\mathrm{F}_{9} \mathrm{NNb}_{2} \mathrm{O}_{2}: \mathrm{C}, 12.75 ; \mathrm{H}, 1.71 ; \mathrm{N}, 2.97 ; \mathrm{Nb}, 36.46$. Found: $\mathrm{C}, 12.70$; $\mathrm{H}, 1.61 ; \mathrm{N}, 3.03 ; \mathrm{Nb}, 36.27$. IR (solid state): $\nu=3381 \mathrm{vw}, 2965 \mathrm{w}$, $1636 \mathrm{vs}\left(\nu_{\mathrm{C}=\mathrm{O}}\right), 1481 \mathrm{~m}, 1346 \mathrm{w}, 1296 \mathrm{w}, 1281 \mathrm{w}, 1234 \mathrm{w}, 1138 \mathrm{w}$, $1073 \mathrm{w}, 1010 \mathrm{w}, 983 \mathrm{~m}, 925 \mathrm{w}, 910 \mathrm{w}, 873 \mathrm{~m}, 765 \mathrm{~m}, 690 \mathrm{vs} \mathrm{cm}^{-1}$. ${ }^{1} \mathrm{H}$ NMR $\left(\mathrm{CD}_{3} \mathrm{CN}\right): \delta=11.77(\mathrm{br}, 1 \mathrm{H}, \mathrm{NH}) ; 4.83(\mathrm{~m}, 1 \mathrm{H}, \mathrm{CH})$;
3.84, $3.70\left(\mathrm{~m}, 2 \mathrm{H}, \mathrm{NCH}_{2}\right) ; 2.60,2.28,2.20\left(\mathrm{~m}, 4 \mathrm{H}, \mathrm{CH}_{2}\right) \mathrm{ppm} .{ }^{19} \mathrm{~F}$ NMR $\left(\mathrm{CD}_{3} \mathrm{CN}\right): \delta=100.9\left(\right.$ decet, $\left.{ }^{1} J_{\mathrm{NbF}}=343 \mathrm{~Hz}, \mathrm{NbF}_{6}{ }^{-}\right) \mathrm{ppm}$.

The reaction of $\mathrm{NbF}_{5}(0.50 \mathrm{mmol})$ with $\mathbf{8 b}(0.50 \mathrm{mmol})$ was performed also inside a sealed NMR tube $\left(\mathrm{CD}_{2} \mathrm{Cl}_{2}, 0.70 \mathrm{~mL}\right)$. A complicated mixture of compounds were detected by NMR, including ethyl fluoride $\left[\delta\left({ }^{1} \mathrm{H}\right)=4.38(\mathrm{~m}), 1.35(\mathrm{t}) \mathrm{ppm} ;{ }^{52}\right.$ $\left.\delta\left({ }^{13} \mathrm{C}\right)=77.6,13.7 \mathrm{ppm} ;{ }^{52} \delta\left({ }^{19} \mathrm{~F}\right)=-209.9(\mathrm{br}) \mathrm{ppm}\right]$. Addition of $\mathrm{D}_{2} \mathrm{O}($ ca. $0.1 \mathrm{~mL})$ to a solution of 10 in $\mathrm{CD}_{3} \mathrm{CN}(0.6 \mathrm{~mL})^{53}$ resulted in the formation of an abundant precipitate; a solution was separated whose ${ }^{13} \mathrm{C}$ NMR analysis evidenced the presence of $\mathrm{L}^{-}$ proline only.

\section{Reactions of $\mathrm{NbCl}_{5}$ with $\alpha$-amino acid esters}

Synthesis and isolation of $\left[\mathrm{NbCl}_{4}\left(\mathrm{Me}_{2} \mathrm{CHCH}_{2} \mathrm{CHNH}_{2} \mathrm{CO}_{2}\right.\right.$ $\left.\mathrm{Me})_{2}\right]\left[\mathrm{NbCl}_{6}\right], \quad 11 \mathrm{a}$, and $\left[\mathrm{NbCl}_{5}\left(\mathrm{Me}_{2} \mathrm{CHCH}_{2} \mathrm{CHNH}_{3} \mathrm{CO}_{2} \mathrm{Me}\right)\right]$ [ $\left.\mathbf{N b C l}_{6}\right]$, 12. A suspension of $\mathrm{NbCl}_{5}(199 \mathrm{mg}, 0.736 \mathrm{mmol})$ in $\mathrm{CH}_{2} \mathrm{Cl}_{2}(15 \mathrm{~mL})$ was treated with $8 \mathbf{k}(97 \mathrm{mg}, 0.74 \mathrm{mmol})$. After $24 \mathrm{~h}$ stirring at room temperature, a pale orange solution was obtained. By addition of hexane, 11a was obtained as a colourless solid. Yield $130 \mathrm{mg}$ ( $44 \%$ based on $\mathrm{Nb}$ ). Anal. calcd for $\mathrm{C}_{14} \mathrm{H}_{30} \mathrm{Cl}_{10} \mathrm{~N}_{2} \mathrm{Nb}_{2} \mathrm{O}_{4}: \mathrm{C}, 20.24 ; \mathrm{H}, 3.64 ; \mathrm{N}, 3.37 ; \mathrm{Cl}, 42.68 ; \mathrm{Nb}$, 22.37. Found: C, 20.05; H, 3.18; N, 3.27; Cl, 42.98; Nb, 23.13. IR (solid state): $\nu=3292 \mathrm{w}\left(\nu_{\mathrm{N}-\mathrm{H}}\right), 3243 \mathrm{w}, 2959 \mathrm{w}-\mathrm{m}, 1633 \mathrm{~m}\left(\nu_{\mathrm{C}}=\right.$ o), $1569 \mathrm{~m}, 1467 \mathrm{~m}, 1387 \mathrm{~m}, 1327 \mathrm{~m}, 1290 \mathrm{w}-\mathrm{m}, 1152 \mathrm{w}-\mathrm{m}, 1123$ $\mathrm{m}, 1015 \mathrm{w}-\mathrm{m}, 934 \mathrm{w}-\mathrm{m}, 856 \mathrm{vs}, 746 \mathrm{~m}-\mathrm{s} \mathrm{cm}^{-1} .{ }^{1} \mathrm{H}$ NMR $\left(\mathrm{CDCl}_{3}\right)$ : $\delta=7.17\left(\mathrm{br}, 2 \mathrm{H}, \mathrm{NH}_{2}\right) ; 4.44(\mathrm{~s}, 3 \mathrm{H}, \mathrm{OMe}) ; 4.40(\mathrm{~m}, 1 \mathrm{H}, \mathrm{CH}) ; 1.96$ $\left(\mathrm{m}, 1 \mathrm{H}, \mathrm{CHMe} \mathrm{Me}_{2}\right) ; 1.51\left(\mathrm{~m}, 2 \mathrm{H}, \mathrm{CH}_{2}\right) ; 1.10(\mathrm{~m}, 6 \mathrm{H}, \mathrm{CHMe}) \mathrm{ppm}$. ${ }^{93} \mathrm{Nb} \mathrm{NMR}\left(\mathrm{CDCl}_{3}\right): \delta=7.8\left(\Delta \nu_{1 / 2}=4 \times 10^{2} \mathrm{~Hz}, \mathrm{NbCl}_{6}{ }^{-}\right) \mathrm{ppm} .{ }^{42 a}$ Hydrolysis ${ }^{53}$ of a $\mathrm{CD}_{3} \mathrm{CN}$ solution $(0.6 \mathrm{~mL})$ of 11a resulted in the formation of an abundant precipitate; a solution was separated whose ${ }^{13} \mathrm{C}$ NMR analysis evidenced the presence of $\mathbf{8 k}$ only.

In a different experiment, the reaction solution was set aside at $c a .-30{ }^{\circ} \mathrm{C}$ for two weeks. Thus pale yellow crystals of 12 were collected. Yield $65 \mathrm{mg}$ (25\% based on $\mathrm{Nb})$. Anal. calcd for $\mathrm{C}_{7^{-}}$ $\mathrm{H}_{16} \mathrm{Cl}_{11} \mathrm{NNb}_{2} \mathrm{O}_{2}$ : C, 11.64; H, 2.23; N, 1.94; Cl, 54.01; Nb, 25.74. Found: C, 11.75; H, 2.16; N, 1.98; Cl, 53.70; Nb, 25.55. IR (solid state): $\nu=3282 \mathrm{w}-\mathrm{br}\left(\nu_{\mathrm{N}-\mathrm{H}}\right), 3241 \mathrm{w}, 2959 \mathrm{w}-\mathrm{m}, 1641 \mathrm{~m}\left(\nu_{\mathrm{C}=\mathrm{O}}\right)$, 1559 m, 1457 m-w, 1377 m, 1327 m, 1281 w-m, 1158 w, 1128 m, $1011 \mathrm{w}-\mathrm{m}, 922 \mathrm{w}-\mathrm{m}, 860 \mathrm{vs}, 744 \mathrm{~m}-\mathrm{s} \mathrm{cm}^{-1}$.

Synthesis of $\left[\mathrm{NbCl}_{4}\left(\mathrm{Me}_{2} \mathrm{CHCH}_{2} \mathrm{CHNH}_{2} \mathrm{CO}_{2} \mathrm{Et}\right)_{2}\right]\left[\mathrm{NbCl}_{6}\right], 11 \mathrm{~b}$, $\left[\mathrm{NbCl}_{4}\left(\mathrm{HNCH}_{2} \mathrm{CH}_{2} \mathrm{CH}_{2} \mathrm{CHCO} \mathrm{CH}_{2}\right)_{2}\right]\left[\mathrm{NbCl}_{6}\right]$, 11c. These products were prepared by a procedure analogous to that described for 11a, from the appropriate niobium pentahalide $(c a .0 .70 \mathrm{mmol}) / \alpha$ amino acid ester combination.

11b. Colourless viscous solid, yield $73 \%$. Anal. calcd for $\mathrm{C}_{16}$ $\mathrm{H}_{34} \mathrm{Cl}_{10} \mathrm{~N}_{2} \mathrm{Nb}_{2} \mathrm{O}_{4}$ : C, 22.38; $\mathrm{H}, 3.99 ; \mathrm{N}, 3.26 ; \mathrm{Cl}, 41.28 ; \mathrm{Nb}, 21.64$. Found: C, 22.25; H, 4.06; N, 3.16; Cl, 41.70; Nb, 21.29. ${ }^{1} \mathrm{H}$ NMR $\left(\mathrm{CDCl}_{3}\right): \delta=7.00\left(\mathrm{br}, 2 \mathrm{H}, \mathrm{NH}_{2}\right) ; 4.50\left(\mathrm{~m}, 2 \mathrm{H}, \mathrm{OCH}_{2}\right) ; 4.31(\mathrm{br}$, $1 \mathrm{H}, \mathrm{CH}) ; 1.96(\mathrm{~m}, 1 \mathrm{H}, \mathrm{CHMe}) ; 1.47\left(\mathrm{~m}, 2 \mathrm{H}, \mathrm{CH}_{2}\right) ; 1.42(\mathrm{~m}, 3 \mathrm{H}$, $\left.\mathrm{OCH}_{2} \mathrm{CH}_{3}\right) ; 1.07\left(\mathrm{~m}, 6 \mathrm{H}, \mathrm{CHMe} e_{2}\right) \mathrm{ppm} .{ }^{13} \mathrm{C} \mathrm{NMR}\left(\mathrm{CDCl}_{3}\right): \delta=$ $170.2(\mathrm{C}=\mathrm{O}) ; 65.5\left(\mathrm{OCH}_{2}\right) ; 54.1(\mathrm{CH}) ; 39.4\left(\mathrm{CH}_{2}\right) ; 25.0\left(\mathrm{CHMe}_{2}\right)$; 22.3, $21.9\left(\mathrm{CHMe}_{2}\right) ; 14.1\left(\mathrm{OCH}_{2} \mathrm{CH}_{3}\right)$ ppm. ${ }^{93} \mathrm{Nb} \mathrm{NMR}\left(\mathrm{CDCl}_{3}\right)$ : $\delta=13\left(\Delta \nu_{1 / 2}=4 \times 10^{2} \mathrm{~Hz}, \mathrm{NbCl}_{6}{ }^{-}\right) ;-540\left(\Delta \nu_{1 / 2}=8 \times 10^{3} \mathrm{~Hz}\right.$, $\left.\mathrm{NbCl}_{4}^{+}\right) \mathrm{ppm}$.

11c. Colourless solid, yield $70 \%$. Anal. calcd for $\mathrm{C}_{14} \mathrm{H}_{26} \mathrm{Cl}_{10^{-}}$ $\mathrm{N}_{2} \mathrm{Nb}_{2} \mathrm{O}_{4}$ : C, 20.34; H, 3.17; N, 3.39; Cl, 42.88; Nb, 22.48. Found: 
Table 4 Crystal data and experimental details for 3, 4, 5a and 12

\begin{tabular}{|c|c|c|c|c|}
\hline & 3 & 4 & $5 a$ & 12 \\
\hline Formula & $\mathrm{C}_{10} \mathrm{H}_{12} \mathrm{Cl}_{8} \mathrm{~N}_{2} \mathrm{Nb}_{2} \mathrm{O}_{2}$ & $\mathrm{C}_{6} \mathrm{H}_{16} \mathrm{Cl}_{6} \mathrm{Nb}$ & $\mathrm{C}_{10} \mathrm{H}_{12} \mathrm{Cl}_{8} \mathrm{~N}_{2} \mathrm{Nb}_{2} \mathrm{O}_{2}$ & $\mathrm{C}_{7} \mathrm{H}_{16} \mathrm{Cl}_{11} \mathrm{NNb}_{2} \mathrm{O}_{2}$ \\
\hline$F w$ & 661.64 & 407.81 & 518.30 & 721.98 \\
\hline Crystal system & Monoclinic & Monoclinic & Orthorhombic & Monoclinic \\
\hline Space group & $P 2_{1} / c$ & $P 2_{1} / c$ & $P 2_{1} 2_{1} 2$ & $P 2_{1}$ \\
\hline$a, \AA$ & $6.7734(9)$ & $8.065(3)$ & $6.9864(4)$ & $10.045(2)$ \\
\hline$\beta, \circ$ & $103.854(2)$ & $94.036(5)$ & 90 & $106.428(3)$ \\
\hline Cell volume, $\AA^{3}$ & $1059.6(2)$ & $1515.1(10)$ & $1874.73(18)$ & $1140.2(5)$ \\
\hline$Z$ & 2 & 4 & 4 & 2 \\
\hline$D_{\mathrm{c}}, \mathrm{g} \mathrm{cm}^{-3}$ & 2.074 & 1.788 & 1.836 & 2.103 \\
\hline$\mu, \mathrm{mm}^{-1}$ & 2.097 & 1.821 & 1.635 & 2.297 \\
\hline$F(000)$ & 640 & 808 & & 700 \\
\hline$w R_{2}$ (all data) & 0.0913 & 0.0870 & 0.0575 & 0.0428 \\
\hline Largest diff. peak and hole, e $\AA^{-3}$ & $2.092 /-1.392$ & $0.769 /-0.891$ & $0.372 /-0.692$ & $0.286 /-0.360$ \\
\hline
\end{tabular}

C, 19.98; H, 3.54; N, 3.47; Cl, 42.09; Nb, 21.79. IR (solid state): $\nu=$ $2961 \mathrm{w}, 2880 \mathrm{w}, 1609 \mathrm{vs}\left(\nu_{\mathrm{C}}=\mathrm{O}\right), 1456 \mathrm{~s}, 1342 \mathrm{w}, 1271 \mathrm{~m}, 1233 \mathrm{w}-\mathrm{m}$, $1052 \mathrm{w}, 974 \mathrm{~m}, 922 \mathrm{w}-\mathrm{m}, 869 \mathrm{~m}, 802 \mathrm{~m}, 756 \mathrm{~m}, 656 \mathrm{w}-\mathrm{m} \mathrm{cm}{ }^{-1} \cdot{ }^{1} \mathrm{H}$ NMR (CD $\mathrm{CDN}_{3}$ ) 7.2 (br, 2H, $\left.\mathrm{NH}_{2}\right) ; 4.73(\mathrm{~m}, 1 \mathrm{H}, \mathrm{CH}) ; 4.31(\mathrm{~m}, 2 \mathrm{H}$, $\left.\mathrm{OCH}_{2}\right) ; 3.79\left(\mathrm{br}, 2 \mathrm{H}, \mathrm{NCH}_{2}\right) ; 2.58,2.18\left(\mathrm{~m}, 4 \mathrm{H}, \mathrm{CH}_{2}\right) ; 1.30(\mathrm{~m}, 3 \mathrm{H}$, $\left.\mathrm{OCH}_{2} \mathrm{CH}_{3}\right)$ ppm. ${ }^{93} \mathrm{Nb} \mathrm{NMR}\left(\mathrm{CD}_{3} \mathrm{CN}\right): \delta=4\left(\Delta \nu_{1 / 2}=3 \times 10^{2} \mathrm{~Hz}\right.$, $\left.\mathrm{NbCl}_{6}{ }^{-}\right) ;-569\left(\Delta \nu_{1 / 2}=2 \times 10^{3} \mathrm{~Hz}, \mathrm{NbCl}_{4}^{+}\right) \mathrm{ppm}$.

Synthesis of $\mathrm{NbCl}_{3}\left(\mathrm{OCH}_{2} \mathrm{CHNHCO}_{2}{ }^{\mathrm{i}} \mathrm{Pr}\right), 13$. A suspension of $\mathrm{NbCl}_{5}(258 \mathrm{mg}, 0.954 \mathrm{mmol})$ and $8 \mathrm{~h}(1.32 \mathrm{~mL}$ of a $0.72 \mathrm{M}$ solution in $\left.\mathrm{CDCl}_{3}, 0.95 \mathrm{mmol}\right)$ in $\mathrm{CHCl}_{3}(8 \mathrm{~mL})$ was refluxed for $31 \mathrm{~h}$. Then, the mixture was allowed to cool to room temperature and the colourless solution was separated from the colourless precipitate. The solid was washed with $\mathrm{CH}_{2} \mathrm{Cl}_{2}(2 \times 5$ $\mathrm{mL}$ ) and dried in vacuo. Yield $239 \mathrm{mg}$ (66\% based on $\mathrm{Nb}$ ). Anal. calcd for $\mathrm{C}_{6} \mathrm{H}_{11} \mathrm{Cl}_{3} \mathrm{NNbO}_{3}$ : Cl, 30.9. Found: $\mathrm{Cl}, 30.8 .{ }^{54}$ IR (solid state): $\nu=3580-3200 \mathrm{br}, 3120 \mathrm{~m}-\mathrm{br}, 2985 \mathrm{~m}, 2965 \mathrm{~m}, 2940 \mathrm{~m}$, $1732 \mathrm{~s}\left(\nu_{\mathrm{C}=\mathrm{O}}\right), 1675 \mathrm{w}, 1576 \mathrm{~m}, 1486 \mathrm{~m}, 1471 \mathrm{~m}, 1387 \mathrm{~m}, 1377 \mathrm{~m}$, 1304 w, 1258 s, 1184 w, 1146 m, 1098 s, 1080 s, 1033 s, 937 m, $895 \mathrm{~m}, 860 \mathrm{w}, 800 \mathrm{~s}, 757 \mathrm{~m} \mathrm{~cm}^{-1} .{ }^{1} \mathrm{H} \mathrm{NMR}\left(\mathrm{CD}_{3} \mathrm{CN}\right): \delta=6.98(\mathrm{br}$, $1 \mathrm{H}, \mathrm{NH}$ ); 5.09 (sept, ${ }^{3} \mathrm{JHH}_{\mathrm{HH}}=6.2 \mathrm{~Hz}, 1 \mathrm{H}, \mathrm{CHMe}$ ); 4.18-4.07 $(\mathrm{m}, 1 \mathrm{H}, \mathrm{NCH}), 4.01-3.92\left(\mathrm{~m}, 2 \mathrm{H}, \mathrm{CH}_{2}\right) ; 1.28\left(\mathrm{~d},{ }^{3} \mathrm{~J}_{\mathrm{HH}}=6.1 \mathrm{~Hz}\right.$, $\left.6 \mathrm{H}, \mathrm{CHMe} e_{2}\right) \mathrm{ppm} .{ }^{13} \mathrm{C}\left\{{ }^{1} \mathrm{H}\right\} \mathrm{NMR}\left(\mathrm{CD}_{3} \mathrm{CN}\right): \delta=167.3(\mathrm{C}=\mathrm{O}) ; 72.2$ $\left(\mathrm{CHMe}_{2}\right) ; 63.4\left(\mathrm{CH}_{2}\right) ; 59.9(\mathrm{br}, \mathrm{NCH}) ; 21.7,21.6\left(\mathrm{CHMe}_{2}\right) \mathrm{ppm}$. ${ }^{93} \mathrm{Nb}\left\{{ }^{1} \mathrm{H}\right\} \mathrm{NMR}\left(\mathrm{CD}_{3} \mathrm{CN}\right): \delta=-493.7\left(\Delta \nu_{1 / 2}=2.3 \times 10^{3} \mathrm{~Hz}\right) \mathrm{ppm}$.

A sample of 13 was suspended in $\mathrm{D}_{2} \mathrm{O}(1 \mathrm{~mL})$ with vigorous stirring for $14 \mathrm{~h}^{53} \mathrm{NMR}$ analysis of the solution revealed the presence of $\mathbf{8 h}$ only ( $\mathrm{pH}=1.8)$.

\section{$\mathrm{MBr}_{5}(\mathrm{M}=\mathrm{Nb}$, Ta) mediated formation of EtBr from L-proline ethylester}

The reactions of $\mathrm{MBr}_{5}(c a .0 .50 \mathrm{mmol})$ with $\mathbf{8 b}(0.50 \mathrm{mmol})$ were carried out in $\mathrm{CD}_{2} \mathrm{Cl}_{2}$ (ca. $1 \mathrm{~mL}$ ). Subsequent NMR analysis pointed out the formation of a complicated mixture of compounds, including ethyl bromide. ${ }^{52}$ In a different experiment, the mixture obtained from $\mathrm{NbBr}_{5} / \mathbf{8 b}$ was eliminated of the volatile materials; the residue was dissolved into $\mathrm{CD}_{3} \mathrm{CN}(0.6 \mathrm{~mL})$ and then treated with $\mathrm{H}_{2} \mathrm{O}(c a .0 .2 \mathrm{~mL}) .^{53} \mathrm{~A}$ yellow solution was separated from an abundant precipitate, and ${ }^{13} \mathrm{C}$ NMR analysis of the solution evidenced the presence of L-proline only.

\section{X-ray crystallographic studies}

Crystal data and collection details for 3, 4, 5a and 12 are reported in Table 4 . The diffraction experiments were carried out on a Bruker APEX II diffractometer equipped with a CCD detector and using Mo-K $\alpha$ radiation $(\lambda=0.71073 \AA$ ). Data were corrected for Lorentz polarization and absorption effects (empirical absorption correction SADABS). ${ }^{55}$ Structures were solved by direct methods and refined by full-matrix leastsquares based on all data using $F^{2}{ }^{26}$ All non-hydrogen atoms were refined with anisotropic displacement parameters. All hydrogen atoms were fixed at calculated positions and refined by a riding model, except hydrogens bonded to N(1) in 4, 5a and 12 which were located in the Fourier map and refined isotropically using the 1.2 fold (for 4 and 5a) and 1.5 fold (for 12) $U_{\text {iso }}$ value of the parent $\mathrm{N}$-atom. The $\mathrm{N}(1)-\mathrm{H}$ distances were restrained to $0.93 \AA$ (s.u. 0.02).

\section{Computational studies}

The computational geometry optimizations were carried out without symmetry constrains using the hybrid-GGA EDF2 functional, ${ }^{57}$ in combination with the $6-31 \mathrm{G}^{* *}$ basis set (ECPbased LANL2DZ basis set for elements beyond $\mathrm{Kr}$ ). ${ }^{58}$ The "restricted" formalism was applied in all cases. The software used was Spartan $08 .^{59}$ Further computational geometry optimizations were carried out without symmetry constrains, using the hyper-GGA functional M06, ${ }^{60}$ in combination with a polarized basis set composed by the $6-31 G(d, p)$ set on the light atoms 
and the ECP-based LANL2TZ(f) on the metal centre. ${ }^{61}$ The CPCM implicit solvation model $(\varepsilon=9.08)$ was added to M06 calculations. ${ }^{62}$ Gaussian '09 was used as software. ${ }^{63}$ All the stationary points were characterized by IR simulations (harmonic approximation), from which zero-point vibrational energies and thermal corrections $(T=298.15 \mathrm{~K})$ were obtained. ${ }^{64}$ Vibrational simulation supported the interpretation of experimental IR data. Cartesian coordinates of the optimized geometries are collected in a separated. xyz file.

\section{Acknowledgements}

The University of Pisa is gratefully acknowledged for financial support.

\section{Notes and references}

1 (a) K. Drauz, I. Grayson, A. Kleemann, H.-P. Krimmer, W. Leuchtenberger and C. Weckbecker, Amino Acids, Ullmann's Encyclopedia of Industrial Chemistry, Wiley-VCH, Weinheim, Germany, 2012, vol. 3, pp. 1-58; (b) K. Araki and T. Ozeki, Amino Acids, Kirk-Othmer Encyclopedia of Chemical Technology, John Wiley \& Sons, Hoboken, NJ, USA, 5th edn, 2004, vol. 2, pp. 554-618.

2 (a) S. Kaneko, Y. Kumatabara and S. Shirakawa, Org. Biomol. Chem., 2016, 14, 5367-5376; (b) M. A. Ashley, J. S. Hieschi, J. A. Izzo and M. J. Vetticatt, J. Am. Chem. Soc., 2016, 138, 1756-1759; (c) X. Zhao, B. Zhou and Z. Jiang, Synlett, 2016, 26, 2216-2230; (d) M. Hibi and J. Ogawa, Appl. Microbiol. Biotechnol., 2014, 98, 3869-3876; (e) P. Singh, K. Samanta, S. K. Das and G. Panda, Org. Biomol. Chem., 2014, 12, 6297-6339; (f) V. Srivastava, Asymmetric organocatalysis, 2013, 1, 8-23; $(g)$ J. G. Hernández and E. Juaristi, Chem. Commun., 2012, 48, 5396-5409; (h) J. Paradowska, M. Stodulski and J. Mlynarski, Angew. Chem., Int. Ed., 2009, 48, 4288-4297.

3 (a) K. M. Engle, Pure Appl. Chem., 2016, 88, 119-138; (b) M. A. Telpoukhovskaia and C. Orvig, Chem. Soc. Rev., 2013, 42, 1836-1846; (c) T. Kiss, J. Inorg. Biochem., 2013, 128, 156-163; (d) J. S. Casas, M. D. Couce and J. Sordo, Coord. Chem. Rev., 2012, 256, 3036-3062; (e) W. Maret, J. Inorg. Biochem., 2012, 111, 110-116; W. Beck, Z. Anorg. Allg. Chem., 2011, 637, 1647-1672. (f) R. H. Fish, Aust. J. Chem., 2010, 63, 1505-1513; (g) K. Severin, R. Bergs and W. Beck, Angew. Chem., Int. Ed., 1998, 37, 1634-1654.

4 (a) R. M. Palou, A. A. Vallejo Cardona, R. J. Reyes Avila, J. Clavel Lopez, C. Bernal Huicochea, M. Ramirez de Santiago and J. A. Aburto Anell, US 2016/0068471 A1, Istituto Mexicano del Petroleo, 2016; (b) G. Lahouar, R. Touati, S. Khamri, J. Marrot and B. Ben Hassine, J. Chem. Pharm. Res., 2015, 7, 283-288; (c) F.-S. He, J.-H. Jin, Z.-T. Yang, X. Yu, J. S. Fossey and W.-P. Deng, ACS Catal., 2016, 6, 652-656; (d) A. K. Padala, R. R. Kumar, S. Athimoolam and Q. N. Ahmed, Org. Lett., 2016, 18, 9699; (e) Y. Kohsaka, Y. Matsumoto and T. Kitayama, Polym. Chem., 2015, 6, 5026-5029; (f) H. Waldmann, Liebigs Ann. Chem., 1990, 671-680.
5 B. Schreiner, B. Wagner-Schuh and W. Beck, Z. Naturforschg., 2010, 65, 679-686; R. Krämer, M. Maurus, K. Polborn, K. Sünkel, C. Robl and W. Beck, Chem.-Eur. J., 1996, 23, 1518-1526; K. Haas and W. Beck, Eur. J. Inorg. Chem., 2001, 2485-2488.

6 G. C. Barrett, Amino Acids, Peptides and Proteins, R.S.C. Publications, London1996, vol. 27, p. 1.

7 R. H. Fish and G. Jaouen, Organometallics, 2003, 22, 21662177.

8 (a) L. Kiss, M. Kardos, E. Forró and F. Fülöp, Eur. J. Org. Chem., 2015, 1283-1289; (b) L. Konnert, B. Reneaud, R. Marcia de Figueiredo, J.-M. Campagne, F. Lamaty, J. Martinez and E. Colacino, J. Org. Chem., 2014, 79, 1013210142; (c) E. A. Egbewande, L. E. H. Paul, B. Therrien and J. Furrer, Eur. J. Inorg. Chem., 2014, 1174-1184; (d) M. Periasamy, R. Gurubrahaman, N. Sanjeevakumar, M. Dalai, L. Anakonda, P. O. Reddy, S. Suresh, S. Satishkumar, M. Padmaja, M. N. Reddy, S. Suresh, S. Anwar, G. P. Muthukumaragopal, P. Vairaprakash and M. Seenivasaperumal, Chimia, 2013, 67, 23-29; (e) V. K. Tandon, D. B. Yadav, R. V. Singh, A. K. Chaturvedi and P. K. Shukla, Bioorg. Med. Chem. Lett., 2005, 15, 53245328; ( $f$ ) S. L. Manjinder, K. R. Yeeman, N. G. J. Michael and C. V. John, J. Org. Chem., 2002, 67, 1536-1547.

9 S. Jugé, J. Bayardon, E. Remond and M.-J. Ondel-Eymin, WO2013030193A1, CNRS and University of Bourgogne, France, 2013; J. Kim, J. Kim, S. Song, O. Jung and H. Suh, J. Inclusion Phenom. Macrocyclic Chem., 2007, 58, 187-192; G. Pollini, N. Baricordi, S. Benetti, C. De Risi and V. Zanirato, Tetrahedron Lett., 2005, 46, 3699-3701; C. Somlai, A. Peter, P. Forgo and B. Penke, Synth. Commun., 2003, 33, 1815-1820; J.-A. Ma, Angew. Chem., Int. Ed., 2003, 42, 4290-4299; T. Zieliński, M. Achmatowicz and J. Jurczak, Tetrahedron: Asymmetry, 2002, 13, 2053-2059.

10 A. C. Fonseca, M. H. Gil and N. P. Simoes, Prog. Polym. Sci., 2014, 39, 1291-1311; A. M. Perez-Lopez, D. GonzalezCalderon, A. Occorso, J. Galindo-Angel, J. F. DominguezSeglar, J. A. Tamayo, M. Diaz-Gavilan and J. A. GomezVidal, Synlett, 2014, 25, 2319-2322; N. H. Powell, G. J. Clarkson, R. Notman, P. Raubo, N. G. Martin and M. Shipman, Chem. Commun., 2014, 50, 8797-8800; E. Aresu, S. Fioravanti, S. Gasbarri, L. Pellacani and F. Ramadori, Amino Acids, 2013, 44, 977-982; R. Katsarava and Z. Gomurashvili, Handbook of Biodegradable Polymers, ed. A. Lendlein and A. Sisson, 2011, pp. 107-131; A. Nagai, T. Miyagawa, H. Kudo and T. Endo, Macromolecules, 2003, 36, 9335-9339; H. Waldmann, Synlett, 1995, 133-141.

11 G. E. Sapper and U. Wannag, Z. Anorg. Allg. Chem., 1975, 417, 41-43.

12 D. S. Aspandiyarova and S. S. Uskova, Izv. Akad. Nauk Kazakhskoi SSR, Ser. Khim., 1983, 76-78; Chem. Abstr., 1983, 98, 209055.

13 (a) C. Evangelisti, M. Hayatifar, F. Marchetti, M. Marelli, G. Pampaloni and F. Piccinelli, Inorg. Chem., 2016, 55, 1816-1820; (b) F. Marchetti, G. Pampaloni and S. Zacchini, RSC Adv., 2014, 4, 60878-60882; (c) F. Marchetti and 
G. Pampaloni, Chem. Commun., 2012, 48, 635-653, and references therein.

14 (a) M. Bortoluzzi, F. Marchetti, G. Pampaloni, M. G. Murrali and S. Zacchini, Dalton Trans., 2014, 44, 8729-8738; (b) M. Bortoluzzi, G. Bresciani, F. Marchetti, G. Pampaloni and S. Zacchini, Dalton Trans., 2014, 44, 10030-10037.

15 M. Bortoluzzi, M. Hayatifar, F. Marchetti, G. Pampaloni and S. Zacchini, Inorg. Chem., 2015, 54, 4047-4055.

16 The pentafluorides of niobium and tantalum have tetranuclear structure in the solid state, ${ }^{17 a}$ while the heavier pentahalides ${ }^{17 \boldsymbol{b}, \boldsymbol{c}}$ are dinuclear in the solid state. All of these compounds will be mentioned by the empirical formulas $\mathrm{MX}_{5}$ throughout this paper.

17 (a) A. J. Edwards, J. Chem. Soc., 1964, 3714-3718; (b) A. F. Wells, Structural Inorganic Chemistry, Clarendon Press, Oxford, 5th edn, 1993; (c) K. Habermehl, I. Pantenburg and G. Meyer, Acta Crystallogr., 2010, 66, i67.

18 (a) G. B. Deacon and R. J. Phillips, Coord. Chem. Rev., 1980, 33, 227-250; (b) S. D. Robinson and M. F. Uttley, J. Chem. Soc., Dalton Trans., 1973, 1912-1920; (c) K. Nakamoto, J. Fujita, S. Tanaka and S. Kobayashi, J. Am. Chem. Soc., 1957, 79, 4904-4908.

19 V. Lacerda Jr, D. Araujo dos Santos, L. C. Da Silva-Filho, S. J. Greco and R. Bezerra dos Santos, Aldrichimica Acta, 2012, 45, 19-27; Y. Satoh and Y. Obora, Eur. J. Org. Chem., 2015, 5041-5054.

20 M. M. Rahman, M. D. Smith and D. V. Peryshkov, Inorg. Chem., 2016, 55, 5101-5103.

21 The combination of $\mathrm{TiCl}_{4}$ with $N, N$-dimethylphenylalanine, in the absence of $\mathrm{NEt}_{3}$, afforded a mixture of two products, that could not be unambiguously characterized.

22 The reaction of the $\mathrm{TiCl}_{4}$ - L-proline adduct $1 \mathrm{a}$ with $\mathrm{NEt}_{3}$ affords is a deep green, paramagnetic compound probably formed via activation reactions involving the amino acid ligand.

23 F. H. Allen, O. Kennard, D. G. Watson, L. Brammer, A. G. Orpen and R. Taylor, J. Chem. Soc., Perkin Trans. 2, 1987, S1-S19.

24 (a) M.-C. Lasne and J.-L. Ripoll, Tetrahedron Lett., 1982, 23, 1587-1588; (b) F. Tureček and Z. Havlas, J. Org. Chem., 1986, 51, 4066-4067.

25 (a) C. A. Buehler and J. O. Harris, J. Am. Chem. Soc., 1950, 72, 5015-5017; (b) E. Lippmann and V. Becker, Z. Chem., 1974, 14, 357-358; (c) M. Weissenfels and J. Punkt, Tetrahedron, 1978, 34, 311-316.

26 C. M. Mayhan, T. J. Szabo, J. E. Adams and C. A. Deakyne, Struct. Chem., 2013, 24, 2089-2099; J. Szklarzewicz and K. Stadnicka, Inorg. Chim. Acta, 2012, 392, 131-136; F. Dong, S. Heinbuch, Y. Xie, J. J. Rocca, E. R. Bernstein, Z.-C. Wang, K. Deng and S.-G. He, J. Am. Chem. Soc., 2008, 130, 1932-1943; A. Kovacs and G. Frenking, Organometallics, 2001, 20, 2510-2524.

27 (a) Y. Tsuda and Y. Okada, Solution-Phase Peptide Synthesis in Amino Acids, Peptides and Proteins in Organic Chemistry, ed. A. B. Hughes, Wiley-VCH, Weinheim, 2011, vol. 3; (b) A. D. Borthwick, Chem. Rev., 2012, 112, 3641-3716.
28 (a) Aminoacids, peptides and proteins in organic chemistry, ed. A. B. Hughes, Wiley, New York, 2011; (b) Á. L. Fuentes de Arriba, L. Simón, C. Raposo, V. Alcázar and J. R. Morán, Tetrahedron, 2009, 65, 4841-4845.

29 M. Bortoluzzi, F. Marchetti, M. G. Murrali and G. Pampaloni, Inorg. Chim. Acta, 2015, 427, 150-154, and references therein.

30 F. Marchetti, G. Pampaloni and C. Pinzino, Chem.-Eur. J., 2013, 19, 13962-13969.

31 The analogous reaction $\mathrm{PCl}_{5} / \mathrm{NbCl}_{5} / \mathrm{L}$-methionine proceeded with clean formation of $\mathrm{POCl}_{3}$, and led to the isolation of a brown, solid product containing $\left[\mathrm{NbCl}_{6}\right]^{-}$, which could not be clearly identified.

32 H. Chen, X. Xu, L. Liu, G. Tang and Y. Zhaoa, RSC Adv., 2013, 3, 16247-16250.

33 (a) M. Bortoluzzi, E. Ferretti, F. Marchetti, G. Pampaloni and S. Zacchini, Dalton Trans., 2016, 45, 6939-6948; (b) W. Levason, M. E. Light, G. Reid and W. Zhang, Dalton Trans., 2014, 43, 9557-9566; (c) R. Bondi, F. Marchetti, G. Pampaloni and S. Zacchini, Polyhedron, 2015, 100, 192198.

34 F. H. Allen, O. Kennard, D. G. Watson, L. Brammer, A. G. Orpen and R. Taylor, J. Chem. Soc., Perkin Trans. 2, 1987, S1-S19.

35 S. Parsons, H. D. Flack and T. Wagner, Acta Crystallogr., 2013, 69, 249-259.

36 C.-I. Bränden and I. Lindqvist, Acta Chem. Scand., 1963, 17, 353-361.

37 D. V. Drobot and E. A. Pisarev, Russ. J. Coord. Chem., 1981, 26, 1-8.

38 M. Bortoluzzi, F. Marchetti, G. Pampaloni and S. Zacchini, Chem. Commun., 2015, 55, 1323-1325.

39 (a) M. Bortoluzzi, F. Marchetti, G. Pampaloni, C. Pinzino and S. Zacchini, Inorg. Chem., 2016, 55, 887-893; (b) M. Bortoluzzi, F. Marchetti, G. Pampaloni and S. Zacchini, New J. Chem., 2016, 40, 8271-8281; (c) M. Bortoluzzi, F. Marchetti, G. Pampaloni and S. Zacchini, Inorg. Chem., 2014, 53, 3832-3838; (d) S. Dolci, F. Marchetti, G. Pampaloni and S. Zacchini, Dalton Trans., 2013, 42, 5635-5648.

40 (a) A. Sferrazza, A. Triolo, L. M. Migneco and R. Caminiti, Curr. Org. Chem., 2015, 19, 99-104; (b) J. Li and Y. Sha, Molecules, 2008, 13, 1111-1119; (c) T. Yamada, P. J. Lukac, T. Yu and R. G. Weiss, Chem. Mater., 2007, 19, 4761-4768; (d) R. H. Mazur, J. A. Reuter, K. A. Swiatek and J. M. Schlatter, J. Med. Chem., 1973, 16, 1284-1287; (e) Q.-Y. Wei, H. Jiang, J.-X. Zhang, C. Zhang and P.-F. Guo, Asian J. Chem., 2012, 24, 2383-2388; (f) R. Quevedo, L. Pabon and Y. Quevedo-Acosta, J. Mol. Struct., 2013, 1041, 68-72; (g) M. van Dijk, T. M. Postma, D. T. S. Rijkers, R. M. J. Liskamp, C. F. van Nostrum and W. E. Hennink, Polymer, 2010, 51, 2479-2485; (h) V. M. Zakharova, M. Serpi, I. S. Krylov, L. W. Peterson, J. M. Breitenbach, K. Z. Borysko, J. C. Drach, M. Collins, J. M. Hilfinger, B. A. Kashemirov and C. E. McKenna, J. Med. Chem., 2011, 54, 5680-5693; (i) T. J. Trivedi, K. S. Rao, T. Singh, S. K. Mandal, N. Sutradhar, A. B. Panda and A. Kumar, 
ChemSusChem, 2011, 4, 604-608; (j) N. Nuñez-Dallos, A. Reyes and R. Quevedo, Tetrahedron Lett., 2012, 53, 530534; (k) I. Aviva and Z. Gross, Chem. Commun., 2006, 44774479; ( $l$ ) H. Chen, M. He, Y. Wang, L. Zhai, Y. Cui, Y. Li, H. Zhou, X. Hong and Z. Deng, Green Chem., 2011, 13, 2723-2726; $(m)$ L. Fabian, M. Gómes, J. A. Caturelli Kuran, G. Moltrasio and A. Moglioni, Synth. Commun., 2014, 44, 2386-2392.

41 (a) M. Hayatifar, F. Marchetti, G. Pampaloni and S. Zacchini, Polyhedron, 2014, 70, 6-10; (b) F. Marchetti, G. Pampaloni, C. Pinzino and S. Zacchini, Eur. J. Inorg. Chem., 2013, 5755-5761; (c) M. Jura, W. Levason, G. Reid and M. Webster, Dalton Trans., 2009, 7610-7612.

42 (a) W. Levason, G. Reid and W. Zhang, J. Fluorine Chem., 2015, 172, 62-67; (b) W. Levason, G. Reid, J. Trayer and W. Zhang, Dalton Trans., 2014, 43, 3649-3659; (c) R. Haiges, P. Deokar and K. O. Christe, Z. Anorg. Allg. Chem., 2014, 640, 1568-1575; (d) M. Jura, W. Levason, R. Ratnani, G. Reid and M. Webster, Dalton Trans., 2010, 39, 883-891.

43 S. L. Benjamin, W. Levason and G. Reid, Chem. Soc. Rev., 2013, 42, 1460-1499.

44 (a) Ru(II): P. Pelagatti, A. Bacchi, F. Calbiani, M. Carcelli, L. Elviri, C. Pelizzi and D. Ragolino, J. Organomet. Chem., 2005, 690, 4602-4610; (b) Ru(II): H. Dialer, P. Mayer, K. Polborn and W. Beck, Eur. J. Inorg. Chem., 2011, 10511055; (c) Ru(II): T. Reiner, D. Jantke, X. Miao, A. N. Marziale, F. Kiefer and J. Eppinger, Dalton Trans., 2013, 42, 8692-8703; (d) Ru(IV): K. Severin, S. Mihan and W. Beck, Chem. Ber., 1995, 128, 1117-1125; (e) Os(II): R. A. Sarfraz, T. G. Kazi, S. Iqbal, H. I. Afridi, M. K. Jamali, N. Jalbani and M. B. Arain, Adv. Organomet. Chem., 2008, 22, 187-192; (f) Co(II): Z. P. Zubreichuk, T. O. Denisova, V. A. Knizhnikov and S. E. Nefedov, Russ. Chem. Bull., 2004, 53, 1770-1772; (g) Co(III): Y. Ohgo, Y. Ohashi, M. Hagiwara, M. Shida, Y. Arai, S. Takeuchi and Y. Ohgo, Acta Crystallogr., 2000, C56, 1062-1064; (h) Rh(I): J. Rauzaud, M. D. Jones, R. Raja, B. F. G. Johnson, J. M. Thomas and M. J. Duer, Helv. Chim. Acta, 2003, 86, 1753-1759; (i) Ru(III), Ir(III), Pd(II): W. Hoffmüller, K. Polborn, J. Knizek, H. Noth and W. Beck, Z. Anorg. Allg. Chem., 1997, 623, 1903-1911; (j) Pt(II): E. Chardon, G. Dahm, G. Guichard and S. Bellemin-Lapollaz, Chem.Asian J., 2013, 8, 1232-1242; (k) Pd(II), Pt(II): E. Schumann, C. Robl and W. Beck, Z. Naturforsch., 1994, 49B, 1569-1579. 45 (a) W.-Q. Zhang, A. C. Whitwood, I. J. S. Fairlamb and J. M. Lynam, Inorg. Chem., 2010, 49, 8941-8952; (b) R. Bergs, R. Krämer, M. Maurus, B. Schreiner, R. Urban, C. Missling, K. Polburn, K. Sunkel and W. Beck, Z. Naturforsch., 1996, 51B, 187-200.

46 P. J. McKarns, M. J. Heeg and C. H. Winter, Inorg. Chem., 1998, 37, 4743-4747.

47 J. M. Wolff and W. S. Sheldrick, J. Organomet. Chem., 1997, 531, 141-149.
48 F. Calderazzo, P. Pallavicini, G. Pampaloni and P. F. Zanazzi, J. Chem. Soc., Dalton Trans., 1990, 2743-2746.

49 (a) A. Jutand, Eur. J. Inorg. Chem., 2003, 2017-2040; (b) W. J. Geary, Coord. Chem. Rev., 1971, 7, 81-122.

50 E. König, Magnetische Eigenschaften der Koordinations und Metallorganischen Verbindungen der Übergangselemente, in Landolt-Börnstein, Zahlenwerte und Funktionen aus Naturwissenschaften und Technik, Springer-Verlag, Berlin, Göttingen, Heidelberg, 6th edn, 1966, vol. 2, p. 16.

51 D. A. Skoog, D. M. West, F. J. Holler and S. R. Crouch, Fundamentals of Analytical Chemistry, Thomson Learning Inc, Belmont, CA, 8th edn, 2004.

52 (a) N. J. R. van Eikema Hommes and T. Clark, J. Mol. Model., 2005, 11, 175-185; (b) Spectral Database for Organic Compounds, SDBS at: http://www.sdbs.db.aist.go.jp/sdbs/ cgi-bin/direct_frame_top.cgi.

53 The addition of water to the reaction mixtures facilitates the release of the organic material from the highly oxophilic metal species, and allows the spectroscopic identification of the former. This strategy has been successfully adopted by ourselves in previous works, having proved that $\mathrm{H}_{2} \mathrm{O}$ is generally inert towards ligand activation reactions. ${ }^{38}$

54 Determined by potentiometric titration at $\mathrm{pH}=2.0$.

55 G. M. Sheldrick, SADABS, Program for empirical absorption correction, University of Göttingen, Göttingen, Germany, 1996.

56 G. M. Sheldrick, SHELX97, University of Göttingen, Göttingen, Germany, 1997.

57 C. Y. Lin, M. W. George and P. M. W. Gill, Aust. J. Chem., 2004, 57, 365-370.

58 (a) M. Dolg, Modern Methods and Algorithms of Quantum Chemistry, ed. J. Grotendorst, John Neumann Institute for Computing, NIC series, Jülich, 2000, vol. 1, p. 479; (b) P. J. Hay and W. R. Wadt, J. Chem. Phys., 1985, 82, 270283; (c) P. J. Hay and W. R. Wadt, J. Chem. Phys., 1985, 82, 299-310; (d) W. J. Henre, R. Ditchfield and J. A. Pople, J. Chem. Phys., 1972, 56, 2257-2261.

59 Spartan '08, version 1.1.1, Wavefunction, Inc., Irvine CA, 2009Except for molecular mechanics and semi-empirical models, the calculation methods used in Spartan have been documented in: Y. Shao, et al., Phys. Chem. Chem. Phys., 2006, 8, 3172-3191.

60 Y. Zhao and D. G. Truhlar, Theor. Chem. Acc., 2008, 120, 215241.

61 (a) L. E. Roy, P. J. Hay and R. L. Martin, J. Chem. Theory Comput., 2008, 4, 1029-1031; (b) M. M. Francl, W. J. Pietro, W. J. Hehre, J. S. Binkley, D. J. DeFrees, J. A. Pople and M. S. Gordon, J. Chem. Phys., 1982, 77, 3654-3665.

62 (a) M. Cossi, N. Rega, G. Scalmani and V. Barone, J. Comput. Chem., 2003, 24, 669-681; (b) V. Barone and M. Cossi, J. Phys. Chem. A, 1998, 102, 1995-2001.

63 M. J. Frisch, et al., Gaussian 09, Revision C.01, Gaussian, Inc., Wallingford CT, 2010.

64 C. J. Cramer, Essentials of Computational Chemistry, Wiley, Chichester, 2nd edn, 2004. 